URANIUM POTENTIAL AND GEOLOGY OF THE CHALLIS VOLCANICS OF THE

BASIN CREEK-YANKEE FORK AREA, CUSTER COUNTY, IDAHO

Department of Geology

College of Mines

University of Idaho

March 1979

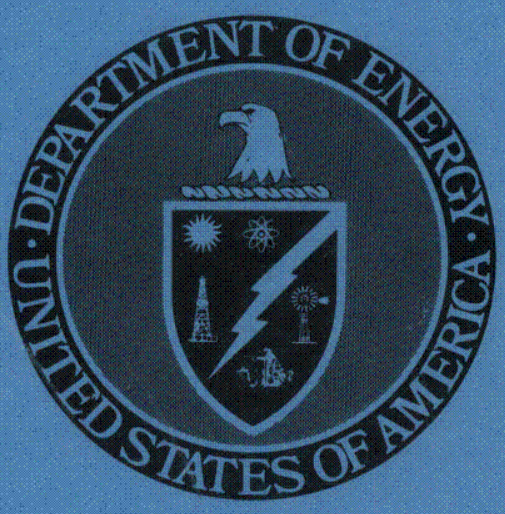

PREPARED FOR THE U.S. DEPARTMENT OF ENERGY GRAND JUNCTION, COLORADO 81501 
This report was prepared as an account of work sponsored by the United States Government. Neither the United States nor the United States Department of Energy, nor any of their employees, nor any of their contractors, subcontractors, or their employees, makes any warranty, express or implied, or assumes any legal liability or responsibility for the accuracy, completeness, or usefulness of any information, apparatus, product, or process disclosed, or represents that its use would not infringe privately owned rights. 
Final Report

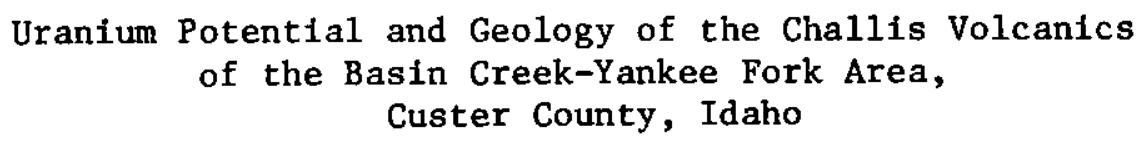

by

Peter L. Siems

Doyle F Albers

Robert W. Malloy

Victoria E. Mitchell

and

Philip C. Perley

Department of Geology

College of Mines

University of Idaho

June 1978

Subcontract No. 77-068-E

To: Bendix Field Engineering Corp. P.0. Box 1569

Grand Junction

Co 81501 



\title{
URANIUM POTENTIAL AND GEOLOGY OF THE CHALLIS VOLCANICS \\ OF THE BASIN CREEK-YANKEE FORK AREA, \\ CUSTER COUNTY, IDAHO
}

\begin{abstract}
Uranium deposits in the area are confined to veins in porphyritic and equigranular phases of quartz monzonite of the Idaho batholith and to stratabound lenses and rolls in a carbonaceous arkosic unit, less than 200 feet thick, that unconformably overlies the batholith and is the lowest stratigraphic unit of the Challis Volcanics. Uranium deposits do not occur in other Challis volcanic units.

Geological mapping demonstrates that the area is at the edge of a major eruptive center that built a 100-cubic-mile volcanic edifice. Early pyroclastic activity in the Eocene deposited up to 1,000 feet of waterlaid tuff and volcanic sandstones that overlie, in part, the uraniferous arkoses. Glass shards in the tuffs and sandstones are devitrified and carbonaceous material is locally abundant but uranium content of these beds is low. Voluminous lava flows of andesite and dacite were discharged after the early eruptions and cover the area to a maximum thickness of 5,000 feet. They are capped by a 1,000-foot thick sequence of air-fall and ash-flow tuffs and lapilii tuff from rhyolite to quartz latite in composition. The tuffs were erupted from numerous small vents that are aligned along the northwest, north and northeast trends of faults. These vents were later plugged by late-stage domes and dikes of rhyolite and, rarely, basalt.

Shallow, low-grade uranium deposits might be discovered in the quartz monzonite phases but the chief potential lies in the discovery of subsurface bedded deposits in the arkoses beneath the Challis Volcanics cover.
\end{abstract}


A number of areas might contain uranium deposits that are larger than those mined but the discovery of these concealed deposits will be difficult by most conventional prospecting techniques. 


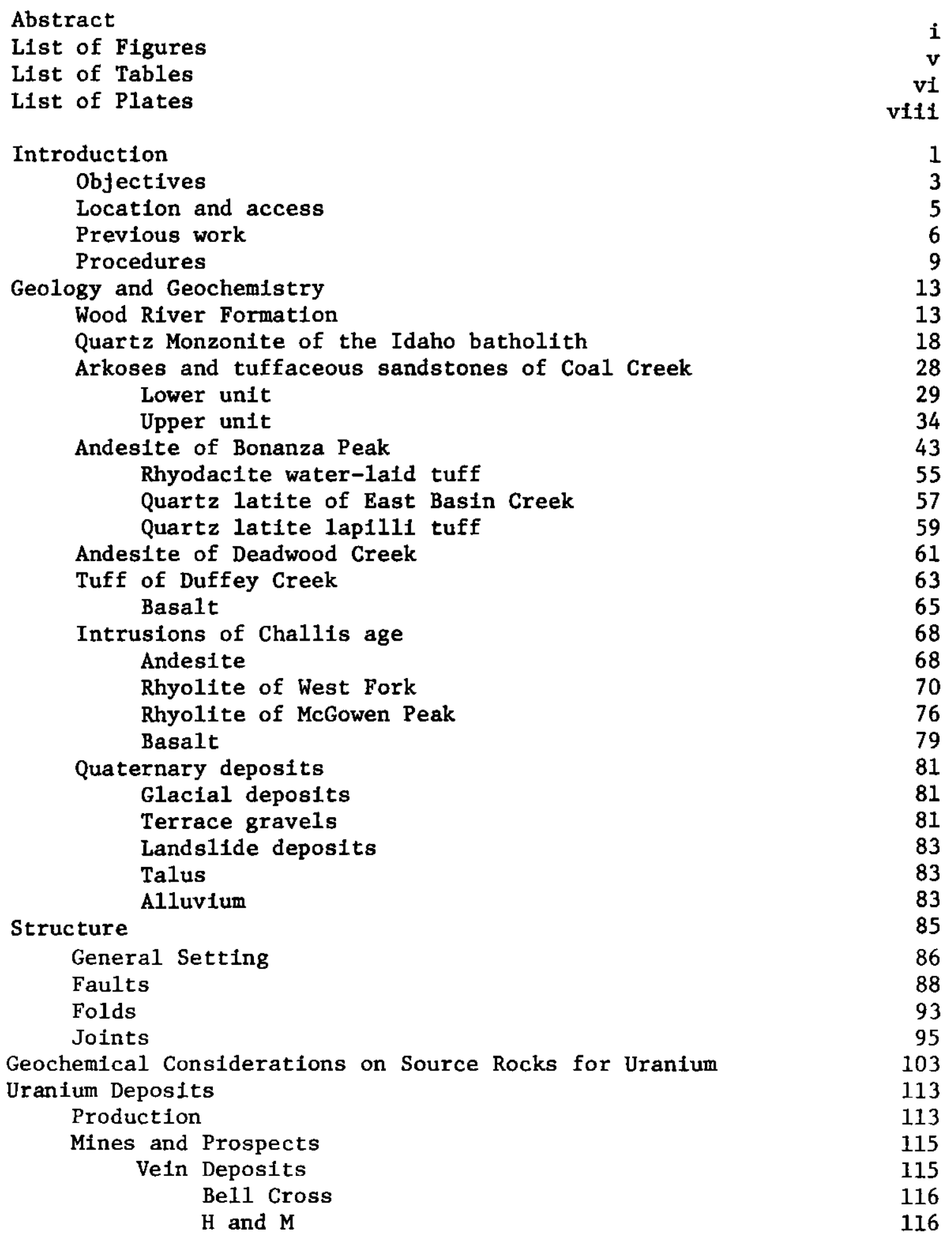


Main Diggings $\quad 117$

Baker and Potato H111 117

Lightning 118

Alta $\quad 120$

Sedimentary Deposits 120

Deer and Elk Strike $\quad 121$

Little Joe $\quad 122$

Lightning No. $3 \quad 123$

Coal Creek 124

East Basin $\quad 125$

Shorty 126

Uranus 126

$\begin{array}{ll}\text { Lucky Strike } & 127\end{array}$

Conclusions

128

Acknowledgments $\quad 134$

References

Appendix Table 1. Major oxide analyses

Table 2. Trace element analyses

Table 3. $\mathrm{U}_{3} \mathrm{O}_{8}$ and Thortum analyses and $\mathrm{Th} / \mathrm{U}$ ratios 
Figure 1.

Joints in equigranular and porphyritic phases of the quartz monzonite of the Idaho batholith

Figure 2.

Joints in the equigranular phase of the quartz monzonite of the Idaho batholith

Figure 3.

Joints in the porphyritic phase of the quartz monzonite of the Idaho batholith

Figure 4. AFM diagram of Challis Volcanics and intrustve rocks

Figure 5. An-Ab-Or diagram of Challis Volcanics and intrusive rocks

Figure 6.

Variation diagram for $\mathrm{K}_{2} \mathrm{O}$ and $\mathrm{SiO}_{2}$ of Challis Volcanics and intrusive rocks 
Table 1.

Table 2.

Table 3.

Table 4.

Table 5.

Table 6.

Table 7.

Table 8.

Table 9.

Table 10.

Table 11.

Table 12 .

Table 13.

Table 14.

Table 15.
Possible relations between $\mathrm{SiO}_{2}$ content and phenocryst constituents of the Challis

Volcanics

Modified from Lipman (1975, p. 5)

15

Modal composition of the equigranular phase of the quartz monzonite of the Idaho batholith

Modal composition of the porphyritic phase of the quartz monzonite of the Idaho batholith

Radiometric analysis of the quartz monzonite of the Idaho batholith along the Salmon River

Modal composition of the quartz latite of East Basin Creek

Modal composition of the tuff of Duffey Creek

Modal composition of the andesite dikes

Modal composition of the rhyolite of West Fork

Modal composition of the rhyolite of McGowan Peak

Comparison of fault and joint trends found in the study area 
Table 16.

Total-count radioactivity measurements for all geologic units

Table 17.

Uranium production, Stanley Area, Custer County, Idaho

114 


\section{PLATES}

1. Geology of the Basin Creek-Yankee Fork area.

in pocket

2. Geological sections of the Basin Creek-Yankee Fork area.

in pocket

3. Total-count radioactivity measurements.

in pocket

4. Locations of geochemical samples.

in pocket

5. Locations of paleomagnetic measurements.

in pocket 


\section{INTRODUCTION}

Uranium was discovered northeast of Stanley in Custer County, Idaho in 1955. At least 25 deposits are now known to occur within the 45-square mile area of the Stanley Basin. Open pit and underground mining of uranium ore started in 1958, reached a peak in 1959, and terminated in 1962. The production from the district to the end of 1960 was 7,767 tons of ore with an average grade of 0.18 percent $\mathrm{U}_{3} \mathrm{O}_{8}$. The reserves of the largest deposit on the Deer Strike and Elk claims in 1962, shortly before it closed, were reported by Choate (1962, p. 60) to be 5,000 tons of 0.20 percent $\mathrm{U}_{3} \mathrm{O}^{\circ}$

The deposits that were mined are of two types:

1) pitchblende-bearing veins of possible hydrothermal origin in quartz monzonite of the Idaho batholith of Cretaceous age, and

2) uraninite- and coffinite-bearing lignitic and arkosic sandstones and conglomerate beds of early Tertiary age in which the uranium mineralization is of possible ground-water origin.

Both types of deposits are located at, closely above, or closely beneath, the unconformable contact of the Idaho batholith and overlying Challis Volcanics (Kern, 1959; Choate 1962).

At the start of the present investigation it was known that some of the uranium-enriched beds dip beneath the Challis Volcanics and it appeared likely that the Challis rocks could conceal more orebodies than those that were exposed. Also, the area whtch may contain concealed, subChallis uranium bodies could be large because lignitic beds similar to those overlaying the bedded deposits also occur on Loon Creek Summit 
approximately 12 miles northeast of Stanley Basin. It was considered possible that sub-Challis uranium bodies which might be amenable to extraction could occur in two general sttuations: (1) where deeply incised valleys have nearly unroofed the Challis Volcanics and Idaho batholith contact, and (2) where elther horst-1ike block faulting or doming caused by Tertiary intrusions has elevated the contact. Those situations could be recognized only when a detailed geological survey, proposed at the start of the present investigation, of the area of Challis Volcanics immediately north of the Stanley Basin would be completed. 


\section{Objectives}

The principal objective of this work is to determine those areas that are favorable for concealed uranium deposits beneath the Challis Volcanic rocks in the area north of the Stanley Basin and south of the West Fork of Yankee Fork (see p1. 1). In order to pursue this objective it is necessary to have some secondary, but essential, objectives. These include the following:

1) to trace and define the faulted or unconformable nature of the contacts between the Idaho batholith and the basal early Tertiary arkosic beds and the Challis Volcanics;

2) to establish the details of the stratigraphy, petrography, thickness, and paleomagnetism of the Challis Volcanics;

3) to establish the presence of faults and their relative displacements in Challis Volcanics and Idaho batholith;

4) to locate areas of the Challis Volcanics where doming by resurgent intrusions might have occurred;

5) to locate possible uplifted fault blocks of Challis Volcanics; and 6) to locate areas of Challis Volcanics where stream or glacial downcutting and valley erosion have nearly unroofed the Idaho batholith;

7) to locate and sample areas of surface radioactivity not identified previously for $K, U$, and $T h$ analyses;

8) to collect a representative suite of Challis Volcanics for determination of $\mathrm{K}, \mathrm{U}, \mathrm{Th}$ and chemical uranium abundances;

9) to determine, wherever possible, the location of and the depth to the arkosic uranium host rocks at the base of the Challis Volcanics; 
10) to identify areas where future drilling might test for the presence of potential deposits of uranium at the base of the Challis Volcanics; and 11) to identify what additional work may be needed to further aid in the evaluation of potential resources of uranium in the study area. 


\section{Location and Access}

The study area is approximately 10 miles northeast of Stanley, Custer County, Idaho and encompasses about 110 square miles. The southern boundary of the area is the Salmon River; from the river the study area extends northward to include the Basin Creek and the western part of the Yankee Fork drainages (p1. 1).

The area is accessible from U. S. Highway 93 on the Salmon River by a road up the Yankee Fork from Sunbeam to the town of Challis, and by many logging and mining roads on Lower and Upper Harden Creeks, American Creek, Rankin Creek, Ramey Creek, and Basin Creek. U. S. Highway 93 is paved and open all year. The Yankee Fork valley has a graded gravel road maintained by the U. S. Forest Service from late May until late October but in other months deep snow closes the road. The mining and logging roads require the use of motorbikes or four-wheel-drive vehicles during the summer and are inaccessible during the winter. A four-wheel-drive vehicular road from the Basin Butte U. S. Forest Service lookout provides access during the summer to Hindman Lake and the Red Mountain area in the northwest of the study area. Several well-maintained U. S. Forest Service trails gave additional access to the study area in 1977.

During the summer months the U. S. Forest Service staffs the Bonanza Guard Station and Custer Museum, which are on the Yankee Fork. The small resorts of Sunbeam at the mouth of the Yankee Fork and Upper and Lower Stanley, provide year-round lodging and food. U. S. Forest Service campgrounds along the Yankee Fork, Basin Creek, and the Salmon River proyide we11-situated campsites. 
Prevlous Work

The earliest geological study was by Umpleby (1913) who brlefly sketched the geology and ore deposits in northwest Custer County, primarily in the Custer, Loon Creek, and Bayhorse areas. Ross (1927) made a reconnalssance study of the ore deposits and volcanic rocks of Tertiary age in the Salmon River Mountains, and, based upon paleontologic data, he believed the volcanic rocks to be of Miocene age. In 1934, Ross named these volcanic rocks the "Challis Volcanics", which "comprised a11 the Tertiary volcanic rock in this part of Idaho except the Snake River Basalt."

The most widespread member of the Challis Volcanics described by Ross is the Latite-andesite Member. The term was first used by Ross (1937) and is simflar to the term "latite and hornblende andesite" of the Wood River region described by Umpleby and others (1930). In the same report (1937), Ross also described the tuffaceous beds as the "Germer Tuffaceous Member" and stated that this member is overlain by the Yankee Fork Rhyolite, described from the Casto quadrangle by Ross in 1934 (p. 52).

Anderson (1949) described the geology and gold-silver deposits of the Yankee Fork mining district and his report is accompanied by a geology map at a scale of $1: 125,000$. Most of the present study area is part of the Yankee Fork mining district. Anderson assigned an 0ligocene age to the Challis Volcanics.

Although there are equivalent rocks of the same age elsewhere in Idaho, Ross (1961), redefined and restricted the term "Challis Volcanics" 
to include "those volcanic rocks within central Idaho north of the Snake River Plain and south of the westward-flowing segment of the Salmon River." Ross supported an 0ligocene age based upon paleontologic data for most of the volcanic rocks.

Ross provided, in 1962, a detailed description of four Challis members: the Latite-andesite Member; Basalt and related Flows; the Germer Tuffaceous Member and its approximate equivalents; and the Yankee Fork Rhyolite. No geologic map accompanied this report.

Ages of Challis volcanic rocks from the general area of Stanley and Challis range from 49.9 to $43.8 \mathrm{~m} . \mathrm{y}$. and fall within the Eocene Epoch (Armstrong, 1975).

Detalled geologic work on the Challis volcanic field in the district around the study area has been carried out by members of the Department of Geology, University of Idaho, since 1970. Graduate students advised by Dr. Peter Siems have examined principally the Challis Volcanics and the associated hydrothermal alteration and gold-silver mineralization in the Yankee Fork and Loon Creek districts. The following theses are adjacent to the present study area: to the northeast, Cass (1973); to the east-northeast, Broili (1974); and to the north, Crist (1978) and Bhatt (1978). Some geology by these authors has been incorporated by us in our Plates 1 and 2 .

Kern (1959) mapped some of the open pits and adits of the uranium mines that were accessible in 1958 and his thesis contains a simple geological map of most of the Stanley Basin district at a scale of 1 to 31,680. Kern concluded that both kinds of uranium deposits are hydrothermal in origin, controlled by a northwest set of fractures and contem- 
poraneous with the Challis eruptions. Further details of the mines and a reconnaissance geology map of the Stanley area at a scale of 1 to 63,360 are given by Choate (1962). A hydrothermal origin for the urantum vein deposits in the Idaho batholith was proposed but, unlike Kern, Choate proposed a syngenetic sedimentary origin in stream channels for the bedded arkosic uranium deposits. Choate's map is a compllation based largely upon the maps of Ross (1934, 1937), Anderson (1949) and Kern (1959). 


\section{Procedures}

The field survey of the study area commenced on June 1, 1977 and ended on September 22, 1977. Geological observations and outcrops were plotted in the field on topographic maps at a scale of 1:6,000. Aerial photographs from the U. S. Forest service at a scale of $1: 15,840$ were used for location in the field. The topographic maps are enlargements of U. S. Geological Survey 7-1/2 minute quadrangle sheets of Sunbeam, Mount Jordan, East Basin Creek, Knapp Lakes, Custer, and Basin Butte, Total count radioactivity was measured in the field by two non-calibrated gammaray scintillometers, Scintrex model GR-101A manufactured by Geometrics, Inc. Remnant paleomagnetic polarity was determined on hand specimens in the fleld by two fluxgate magnetometers, model 70 manufactured by the California Electronic Manufacturing Co. All fleld observations were transferred in the laboratory to a 1:6,000-scale topographic map mylar base and later reduced to a 1:24,000-scale base (see plates $1,3,4$, and 5).

In the 1aboratory 211 thin sections of rock were made for petrographic examination. One hundred and ninety-seven hand specimens of rocks were sawn into slabs and stained by sodium cobaltinitrate, according to the method of Williams (1960), in order to determine their contents of potasstum feldspar. The thin sections were examined on Leitz or Zeiss rotatingstage polarizing microscopes. The anorthite content of the plagioclase feldspar was determined by the albite-Carlsbad twin method or by the Miche1-Levy method. Identifications of sllicate minerals in thin sections follow the data of Kerr (1959). Rock colors are described according to the Rock Color Chart of the Geological Society of America (1963). Pyroclastic 
rocks are classified according to Fisher $(1960,1966)$ and sedimentary rocks according to Pettijohn, Potter and Siever (1972). On the basis of petrographic examination, the igneous rocks are named according to Peterson (1961).

There is considerable uncertainty, however, in the assignation of a petrologic name to many Challis volcanic rocks for they are, at least, partly glassy or contain devitrification products that are difficult, or impossible, to resolve under the petrographic microscope. Most volcanic rocks should be named on the basis of their chemistry. For these reasons, 50 samples were selected and submitted for analysis of their major oxide contents. Tuffaceous rocks were not selected for analysis because of the high possibility of alkall metal exchange with ground waters. Twenty-eight samples were analyzed by a X-ray fluorescence technique at the laboratories of Bendix Field Engineering Corp. The remainder of the samples, 22, were analyzed by one of us (D.F.A.) on a Phillips P.W. $1410 \mathrm{XRF}$ instrument at Washington State University, Pullman.

The major oxide analyses have been recalculated to 100 percent free of volatiles in order to facilitate comparison among the samples. Norms for the analyzed rocks were calculated with the use of the U. S. Geological Survey's Graphic Normative Analysis Program (GNAP), Program C542 (Bowen, 1971). Petrologic names based on chemical composition were assigned to the analyzed rocks on the basis of the silica concentrations In Carmichael, Turner and Verhoogen (1974). The resulting divisions are 
Rock Name

Basalt

Basaltic Andesite

Andesite

Dacite

Rhyodacite

Rhyolite
Percent $\mathrm{SiO}_{2}$

$$
\begin{array}{r}
52 \\
52-55 \\
55-63 \\
63-68 \\
68-72 \\
72
\end{array}
$$

These divisions appear to generally coincide with the phenocryst variations observed. Lipman (1975, p. 5) found that in the volcanic rocks of the San Juan Mountafns, Colorado the phenocryst assemblage could be related to the $\mathrm{SiO}_{2}$ content of the rock. The Challis Volcanics are similar in mineral and chemical composition to the volcanic rocks of the San Juan Mountains. Therefore, when volcanic rocks from the study area are studied without being analyzed for their major oxides, they can be compared and classified by their phenocryst assemblage as shown in Table 1 .

Trace element concentrations for 31 elements in 140 rock samples were analyzed with a semi-quantitive emission spectrographic technique by Specomp Services Inc. of Steamboat Springs, Colorado. Uranium and thorium concentration in the 140 samples were determined by Bendix Field Engineering Corp. laboratories with a total chemical fluorometric method. All trace element analyses were tabulated by a computer program written by R. W. Malloy and F. C. Perley. Joints were measured in the field and were plotted on equal area nets by a computer program of the U.S. Geological Survey that was modified by R. W. Malloy. 
Table 1. Possible relations between $\mathrm{SiO}_{2}$ content and phenocryst constituents of the Challis Volcanics.

Modified from Lipman (1975, p. 5).

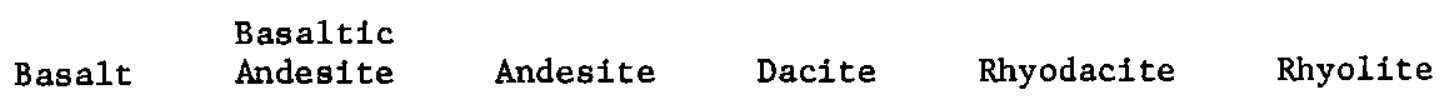

Quartz

Sanidine

Plagloclase

Blotite

Ho rnblende

Augite

Olivine

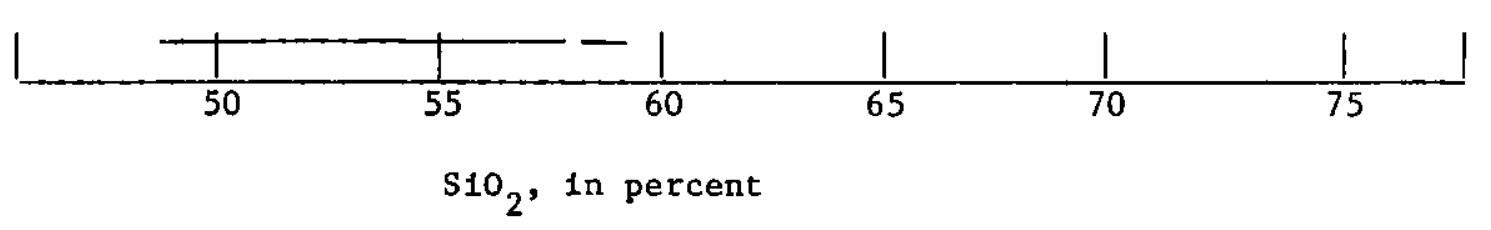


GEOLOGY AND GEOCHEMISTRY

Wood River Formation

The oldest stratigraphic unit in the Salmon River-Yankee Fork confluence area is correlated with the Wood River Formation on the basis of 1ithology and stratigraphic relations. This formation was described by Umpleby and others (1930) from the Wood River region near Hafley, Idaho, and the correlation was first suggested by Ross(1937). Sedimentary quartzites, arenaceous limestones, and thin partings of shale are found in the type area. Hall, Batchelder, and Douglas (1974) have subdivided the Wood River Formation into seven units in the type area. The 11thologies of the rocks in the study area are simflar to the Iithologies ascribed by Hall and others (1974, p. 94-95) to the uppermost unit, Unit 7 (D.A. Seeland, oral communication 1978).

The Wood River Formation covers several square miles north and east of Polecamp Flat campground on the Yankee Fork (p1. 1). The best exposures are found along roadcuts on the eastern side of the Yankee Fork valley. This formation underlies wel1-rounded sol1-covered slopes and is best exposed on ridgetops and along the Yankee Fork valley as rubble-strewn, goethite-stained and rounded outcrops. The beds have attitudes of approximately N. $05^{\circ}$ W., $20^{\circ}$ E. except near the Idaho batholith contact where the beds have been overturned to a strike of $\mathrm{N} .10^{\circ} \mathrm{W}$. and a dip of $75^{\circ} \mathrm{E}$. The formation also occurs as small roof pendants in the equigranular quartz monzontte of the Idaho batholith on the ridge near the mouth of Sawmill Creek. 
The dominant rocks of this unit are graphitic phyllites although a 500-foot thick bed of calcareous phyllite is found approximately 1 mile up Ramey Creek. The calcareous phyllite is interbedded with 20-foot thick beds of limestone, which form distinct ledges. The limestone has been slightly recrystallized to a medium-grained texture because of thermal metamorphism.

The phyllites have laminated $5 \mathrm{~mm}$ thick beds which are graded and contain ripple marks and crossbeds. The measurement of one crossbed 1 mile up Ramey Creek indicates a N. $30^{\circ}$ W.-trending paleocurrent. The graphitic phyllites are moderately brown (5 YR 4/4) when weathered and medium dark gray (N4) when fresh. The unweathered calcareous phyllite and limestones are very light gray (N8).

The phyllites are lepidoblastic, fine-grained and contain $0.1 \mathrm{~mm}-$ size particles. Schistosity and relict bedding are generally parallel in outcrops observed in the area. Table 2 shows the visually determined mineral compositon of four thin sections.

The quartz is granular and found in monolithologic graphite-rich layers which are about $0.5 \mathrm{~mm}$ thick and possibly aligned parallel to the bedding. Muscovite is colorless, lathlike, and $0.3 \mathrm{~mm}$ in size and aligned to form distinct mica-rich layers. The layers have some crinkle folds that are syncrystalline with polygonal folds, which were formed when the quartz monzonite intruded the phyllite. The biotite is reddish brown, lathlike, poikilitic, and $0.5 \mathrm{~mm}$ in size and crosscuts the schistosity. This biotite results from a later thermal event produced when the nearby andesite dikes of Challis age intruded the phyllites.

The calcareous phyllites contain quartz, muscovite and biotite as 
Table 2. Modal composition of the Wood River Formation

\begin{tabular}{lcccc}
\multicolumn{5}{c}{ Volume percent visually estimated from thin sections } \\
Sample Number & 8911 & 8101 & 9101 & 9105 \\
Rock Name & $\begin{array}{c}\text { Calcareous } \\
\text { phylite }\end{array}$ & $\begin{array}{l}\text { Muscovite } \\
\text { phylite }\end{array}$ & $\begin{array}{c}\text { Calcareous } \\
\text { phylite }\end{array}$ & $\begin{array}{c}\text { Silty } \\
\text { 1imestone }\end{array}$ \\
Quartz & & & & 35 \\
Muscovite & 20 & 45 & 40 & 2 \\
Biotite & -- & 40 & 1 & - \\
Graphite & -- & 5 & -- & -- \\
Calcite & trace & 3 & 14 & 55 \\
Diopside & 15 & -- & 35 & 6 \\
Tremolite & 25 & -- & 7 & -- \\
Plagioclase & 3 & -- & trace & -- \\
Wollastonite & 2 & -- & 3 & -- \\
Idocrase & 25 & -- & -- & -- \\
Apatite & 2 & -- & -- & trace \\
Sphene & trace & -- & trace & trace
\end{tabular}

SAMPLE LOCATIONS

8911. Mouth of Rankin Creek on Yankee Fork

8101. Mouth of Crealey Creek on Yankee Fork

9101. North side of Ramey Creek, 4,000 feet east of Yankee Fork

9105. North side of Ramey Creek, 1 mile east of Yankee Fork 
well as calcite, diopside, tremolite, and albite. The mineralogy in this unit is dependent on the amount of $\mathrm{CaCO}_{3}$ originally avallable to form the calc-silicates. Calcite is granular, colorless, $0.5 \mathrm{~mm}$ in diameter, and forms irregular bands. Diopside is $0.3 \mathrm{~mm}$ in diameter, colorless, and subhedral, except when graphite is present. When present, graphite appears as a black dusting.

Tremolite is found in diopside-rich layers as colorless, anhedral 1.5-mm-long porphyroblasts that are partly replaced. The limestone interbeds have wollastonite in addition to the above minerals. Wollastonite is found as colorless, subhedral crystals in fibrous and radiating groups. Plagiocalse is colorless, anhedral, $0.2 \mathrm{~mm}$ in diameter, and cuts across the wollastonite-rich layers as a late-stage mineral. Magnetite is present in minor amounts, and generally occurs as anhedral grains less than $0.3 \mathrm{~mm}$ in size. These crystalloblasts are dominantly associated with the coarse-grained quartz and calcite layers. Accessory minerals include: apat1te, scheelite, and plagloclase.

The phyllites and limestones appear to have gradational contacts. The base of the unit is not exposed. The late Cretaceous-age quartz monzonite of the Idaho batholith has intruded and thermally metamorphosed the Wood River Formation. Andestites unconformably overlie the unit 1.5 miles up Ramey Creek, while further north phyllites have been uplifted almost 2,000 feet relative to the andesites of Bonanza Peak by a normal fault (p1, 1).

The phyllite is in fault contact with lava flows of Challis age north and west of Sawmill Creek. This unit is known to underlie a large portion of the terrace gravels and alluvium of the Yankee Fork valley in the north- 
east part of the area. The skarns, now calc-silicate layers resulted from metamorphism of limy interbeds in the Wood River Formation.

Fusulinids and crinoidal calcarente found in the type area for the Wood River Formation indicate that the formation was deposited in the early Permian (Leonardian) Epoch (Hall and others, 1974, p. 94 and 95). The formation was later subjected to thermal metamorphism when the quartz monzonite batholith of late Cretaceous age was emplaced. The mineral assemblage observed indicates that the metamorphism was probably no higher than the upper greenschist facies (Jackson, 1970, p. 223). The Challis volcanic event caused some local minor metamorphic recrystallization around andesite dikes. Blotite that is cutting across the schistosity is a clear indication of this minor metamorphic event which probably extends no further than 50 feet from dike contacts. 
Quartz Monzonite of the Idaho Batholith

The quartz monzonite is part of the Idaho batholith and was described in the study area previously in a study by Choate (1962, p. 8).

The unit is found north of the Salmon River and surrounds the Challis Volcanics terrain in the study area on all sides except the north and nor theast $(\mathrm{pl}, 1)$.

The quartz monzonite underlies well-rounded, grus-covered slopes. The outcrops are best found on ridgetops, along the Salmon River and the lower 3 miles of the Yankee Fork, where these two rivers have rapidly downcut into the bedrock, and southwards from Cabin Creek Peak to the north of Sunday Creek. Outcrops in areas outside those just mentioned are not common and tend to be highly weathered, rounded, and low-1ying.

The quartz monzonite occurs as two distinct phases, a porphyritic phase ( $\mathrm{K}_{\mathrm{p}}$ on plate 1 ) around the Salmon River, Potato Mountain, and Cabin Creek Peak, and an equigranular phase (Ke), along the Yankee Fork in the Rankin Creek-Blind Creek drainages and the Basin Creek drainage (p1. 1). The porphyritic phase contains from 5 to 20 percent euhedral phenocrysts of random1y oriented grayish-orange-pink (5 YR 7/2) microcline ranging from $1 / 2$ to 2 inches in length. This phase is moderate orange pink (10 R 7/4) when weathered and pale yellowish brown (10 YR 6/2) to light gray (N8) when fresh, medium to coarse-grained, and very similar to the equigranular quartz monzonite with the exception of the phenocrysts of microcline.

The equigranular phase is grayish pink $(5 \mathrm{R} 8 / 2)$ to light gray when fresh, medium - to coarse-grained, and hypidiomorphic-granular. The equi- 
granular quartz monzonite in places grades into the porphyritic phase over distances from 100 to 200 feet. The two phases have similar mineralogical compositions.

Tables 3 and 4 show the visually estimated mineral percentages of 13 thin sections of the quartz monzonite. The minerals have the following microscopic characteristics. Quartz is colorless, about $1.5 \mathrm{~mm}$ in diameter, anhedral, interstitial between the feldspar crystals, and has undulatory extinction. Plagioclase feldspar is colorless, $2 \mathrm{~mm}$ to $3 \mathrm{~mm}$ wide, and subhedral. Some plagioclase is zoned normally with an $\mathrm{An}_{25}$ rim and an $\mathrm{An}_{47}$ core. Inclusions of apatite (colorless, $0.4 \mathrm{~mm}$ in size, euhedral blades) and zircon (colorless, $0.2 \mathrm{~mm}$ in size, euhedra1) are found in trace amounts in the plagloclase. Kaolinite forms along fractures and grain boundaries because of weathering. Orthoclase is colorless, $2 \mathrm{~mm}$ to $3 \mathrm{~mm}$ wide, and anhedral. Myrmekftic intergrowths occur at the quartzorthoclase boundary. Kaolinite forms along fractures because of weathering. Microcline is colorless, $10 \mathrm{~mm}$ to $30 \mathrm{~mm}$ wide, subhedral to euhedral, poikilitic, and porphyritic. Inclusions of all the other minerals occur within these poikilitic phenocrysts. Biotite is brownish green to green, $1.5 \mathrm{~mm}$ wide, and forms ragged anhedral to subhedral randomly oriented flakes. The biotite alters to intergrowths of muscovite, magnetite and chlorite. The dark brownish green biotite observed in specimen 8-18-3 is possibly secondary, the result of a hydrothermal overprint from a nearby gold-bearing chert vein. Biotite is a common accessory mineral. Hornblende is dark green to olive green, $1.7 \mathrm{~mm}$ in length, and subhedral. Goethite forms along the fractures because of weathering. 
Table 3. Modal composition of the equigranular phase of the quartz monzonite of the Idaho batholfth

Volume percent visually estimated from thin sections

\begin{tabular}{|c|c|c|c|c|c|c|c|c|}
\hline Sample Number & MAS680** & MAS 708* & $9.08-1$ & $9.08-3 \mathrm{~B}$ & $9.13-1 \mathrm{~B}$ & $9.18-16 \mathrm{~B}$ & $9.19-4 \mathrm{~B}$ & $9.21-1$ \\
\hline Rock Name & $\begin{array}{c}\text { Equigranular } \\
\text { quartz } \\
\text { monzonite }\end{array}$ & $\begin{array}{c}\text { Equigranular } \\
\text { quartz } \\
\text { monzonite }\end{array}$ & $\begin{array}{c}\text { Equigranular } \\
\text { quartz } \\
\text { monzonite }\end{array}$ & $\begin{array}{c}\text { Equigranular } \\
\text { quartz } \\
\text { monzonite }\end{array}$ & $\begin{array}{c}\text { Equigranular } \\
\text { quartz } \\
\text { monzonite }\end{array}$ & $\begin{array}{c}\text { Equigranular } \\
\text { quartz } \\
\text { monzonite }\end{array}$ & $\begin{array}{c}\text { Equigranular } \\
\text { quartz } \\
\text { monzonite }\end{array}$ & $\begin{array}{c}\text { Equigranular } \\
\text { quartz } \\
\text { monzonite }\end{array}$ \\
\hline Quartz & 35 & 30 & 30 & 35 & 30 & 25 & 25 & 33 \\
\hline Potassium feldspar & 25 & 18 & 25 & 15 & 25 & 30 & 20 & 40 \\
\hline Plagioclase & 35 & 30 & 43 & 39 & 36 & 36 & 32 & 25 \\
\hline Biotite & 3 & 7 & - & 9 & 8 & 5 & 10 & 1 \\
\hline Hornblende & -- & - & - & - & - & - & - & - \\
\hline Sphene & -- & trace & - & - & -- & -- & -- & -- \\
\hline Magnetite & trace & trace & 1 & 1 & trace & trace & 1 & 1 \\
\hline Muscovite & 0.5 & 1 & 1 & $\begin{array}{l}1 \\
1\end{array}$ & 1 & trace & - & trace \\
\hline Apatite & - & $\begin{array}{l}1 \\
--\end{array}$ & - & trace & trace & trace & - & - \\
\hline Zircon & -- & -- & -- & trace & trace & trace & -- & trace \\
\hline Calcite & -- & $\cdots$ & - & - & - & -- & 2 & - \\
\hline
\end{tabular}

* Analyzed for trace elements

** Analyzed for trace elements and major oxides

SAMPLE LOCATIONS

MAS630. See plate 4.

MAS708. See plate 4.

9.13-1B. SWI/4NE1/4 sec. 1, T. $11 \mathrm{~N} ., \mathrm{R} .13 \mathrm{E}$.

9.18-16B. NE1/4NW1/4 sec. $21, T .11 \mathrm{~N} ., R_{0} 14 \mathrm{E}$

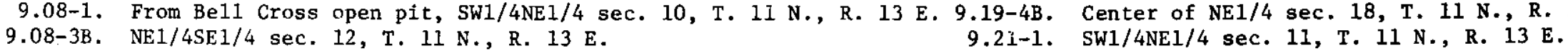


Table 4. Modal composition of the porphyritic phase of the quartz monzonite of the Idaho batholith

Volume percent visually estimated from thin sections

\begin{tabular}{|c|c|c|c|c|c|}
\hline Sample Number & 8183 & MAS 701* & MAS706** & $8.27-5$ & $9.21-17 \mathrm{~B}$ \\
\hline Rock Name & $\begin{array}{l}\text { Porphyritic } \\
\text { quartz } \\
\text { monzonite }\end{array}$ & $\begin{array}{l}\text { Porphyritic } \\
\text { quartz } \\
\text { monzonite }\end{array}$ & $\begin{array}{l}\text { Porphyritic } \\
\text { quartz } \\
\text { monzonite }\end{array}$ & $\begin{array}{l}\text { Porphyritic } \\
\text { quartz } \\
\text { monzonite }\end{array}$ & $\begin{array}{l}\text { Porphyritic } \\
\text { quartz } \\
\text { monzonite }\end{array}$ \\
\hline Quartz & 40 & 35 & 30 & 25 & 35 \\
\hline Potassium feldspar & 30 & 25 & 20 & 33 & 20 \\
\hline Plagioclase & 25 & 25 & 35 & 35 & 35 \\
\hline Biotite & 15 & 10 & 12 & 3 & 8 \\
\hline Hornblende & 5 & -- & -- & -- & -- \\
\hline Sphene & 1 & trace & 2 & trace & -- \\
\hline Magnetite & 1 & 5 & trace & 1 & 2 \\
\hline Muscovite & -- & trace & -- & trace & trace \\
\hline Sericite & -- & -- & -- & 3 & -- \\
\hline Calcite & -- & -- & -- & 3 & -- \\
\hline
\end{tabular}

\section{SAMPLE LOCATIONS}

8183. Warren mine, $1-1 / 2$ miles up Rankin Creek.

MAS701. See plate 4.

MAS706. See plate 4.

8.27-5. SEcornerNE1/4 sec. 17, T. $11 \mathrm{~N} .$, R. $14 \mathrm{E}$.

3.21-17B. NE1/4SW1/4 sec. 21, T. 11., T. 11 N., R. 14 E. 
Muscovite occurs as shreds or as platy crystals with cleavage traces, and may be bent around surrounding crystals. The muscovite ranges from 0.2 to $1.8 \mathrm{~mm}$ in length and from 0.05 to $0.3 \mathrm{~mm}$ in width. The magnetite occurs as steel black, opaque, euhedral to subhedral crystals. The magnetite grains are 0.05 to $0.3 \mathrm{~mm}$ in diameter. In places, the magnetite is altered to bright red hematite. Zircon occurs as small euhedral prisms about 0.05 to $0.10 \mathrm{~mm}$ in length and about $0.05 \mathrm{~mm}$ in diameter. Apatite occurs as small euhedral prismatic crystals about 0.05 to $0.40 \mathrm{~mm}$ in length and 0.01 to $0.15 \mathrm{~mm}$ in diameter. Rutile occurs as small brownish acicular crystals found as inclusions in one-tenth to one-half of the quartz crystals in the rock. The rutile needles range up to $0.15 \mathrm{~mm}$ in length. Calc1te occurs as irregularly shaped patches that replace the plagioclase. In places, calcite may also be found within the potassium feldspar crystals. The calcite patches range up to $0.3 \mathrm{~mm}$ in diameter.

Both phases of the quartz monzonite contain biotite-rich pods from 6 to 12 inches long and wide, and from 2 to 4 inches in thickness with sharp contacts. These pods are fine- to medium-grained, hypidiomorphicgranular and contain a maximum of 35 percent biotite. They appear to be oriented with the long axis trending $\mathrm{N}, 60^{\circ} \mathrm{W}, 43^{\circ} \mathrm{W}$. and occur along the edges of some pegmatite dikes. These mafic pods are possibly latestage differentiates from the quartz monzonite or xenoliths of the Woods River Formation.

Both phases of the quartz monzonite are cut by aplite and pegmatite dikes. The aplite dikes are from 1 inch to 20 feet wide, light brown (5 YR 6/4) to grayish orange pink (5 YR 7/2), and very fine to fine-grained. 
They have a $2 \mathrm{~mm}$ wide fused boundary with the quartz monzonite and make up from 3 percent to 5 percent of the batholith, although near the Salmon River-Yankee Fork confluence aplite dikes may make up to 20 percent of the batholith. The greater volume of aplite dikes at the confluence may indicate that the solidified quartz monzonite in the area was fracturing over a cooling but still growing mass of magma (Balk, 1937, p. 33). Along the contact with the Wood River Formation one pegmatite dike intrudes the Paleozolc rocks. The other aplite and pegmatite dikes are confined to the quartz monzonite.

The pegmatite dikes are from 2 in. to $3 \mathrm{ft}$ wide, and contain anhedral crystals of microcline and quartz at least $6 \mathrm{in}$. in size and books of biotite and some muscovite $1 / 4 \mathrm{in.} \mathrm{thick} \mathrm{and} \mathrm{from} 1$ in. to 2 in. in width. The pegmatites contain symmetrical zones with a quartz- and mica-rich core and an outer zone of microcline. The zonation may be repeated outwards several times. Pegmatites also form lenticular bodies in aplite dikes. The quartz monzonite is fused at the boundary with the pegmatite dikes.

Both types of dikes appear to occupy sharply defined fractures and joints. The dikes are often intruded by other aplite or pegmatite dikes and the cross-cutting relations indicate that three or more injection episodes of aplite and pegmatite may have occurred.

These dikes were probably injected after the quartz monzonite had crystallized because the dike boundaries are sharp and fused. They formed when the residual solution of the quartz monzonite parent magma escaped along the primary cooling joints in the solidifled quartz monzonite. 
The major oxide analyses (Appendix 1) show that the quartz monzonite is peraluminous and therefore rich with respect to aluminum. Secondly, the porphyritic and equigranular phases are almost chemically equivalent. Therefore, both phases probably have come from the same parent magma, and crystallized under almost the same conditions. Slight differences in the joint patterns developed in the two phases indicating that the phases have been subjected to different stress regimes and that there is some difference in age between the two phases (see p. 100). The porphyritic phase is believed to be the older of the two.

The trace element analyses (Appendix 2), in general, are similar to analyses on quartz monzonites found in other areas (Nockolds and Allen, 1953, p. 112). Two exceptions are present, however: (1) the Sr content is significantly higher than the normal concentration of $300 \mathrm{ppm} \mathrm{Sr}$; and (2) the $\mathrm{Pb}$ content is slightly higher than the normal concentration of 10 $\mathrm{ppm} \mathrm{Pb}$. The normal variations in plutonic bodies may account for these deviations.

The quartz monzonite apparently has intruded the Wood River Formation In the eastern part of the area; however, Intrusive contacts are irregular and difficult to map due to poor exposure in this part. A quartz monzonite dike about 300 feet long and 20 feet wide intrudes the Paleozoic rocks south of the West Fork and north of Sawmill Creek (p1. 1). This dike is parallel to a major fault with a northeast trend along the Sawmill Creek drainage. Two large blocks of Paleozolc rocks, each about 200 feet by 400 feet in area crop out on the ridge east of Sawmil1 Creek (p1. 1). These blocks have been rotated relative to other phyllite outcrops in the area. The isolation of these blocks within the quartz monzonite, together 
with the change in attitudes, indicate that these phyllite blocks may be either roof pendants or foundered blocks on the roof within the batholith.

The quartz monzonite is in fault contact with, as well as overlain by, Challis volcanic rocks. A major fault dividing these two rock units trends northeast through the Sawmill Creek drainage basin. This is a high-angle normal fault along which the volcanic rocks have been downdropped relative to the batholith.

The contact between the porphyritic quartz monzonite and the overlying units is in a few places erosional and unconformable; in other places the contact is faulted. The arkosic unit of the arkoses and tuffaceous sandstones of Coal Creek was deposited by stream channels developed on the weathered porphyritic quartz monzonite. Where the arkoses and tuffaceous sandstones of Coal Creek were not deposited or were eroded, the andesite of Bonanza Peak may rest directly on the porphyritic quartz monzonite. However, in most places the andesite of Bonanza Peak is in fault contact with the porphyritic quartz monzonite.

The quartz monzonite was possibly formed with the partial melting of a Cretaceous-age subducted plate. The $\mathrm{Rb} / \mathrm{Sr}$ and $\mathrm{Sr}^{87} / \mathrm{Sr}^{86}$ ratios taken from rocks analyzed by Armstrong (1975, p. 59) in the study area (Table 5) indicate that the quartz monzonite was derived possibly at a depth of $300 \mathrm{~km}$ from basalts on a subducting plate dipping 20 degrees eastward during the Cretaceous (Lipman and others, 1971, p. 824).

Strontium isotope ratios have been used to determine the nature of the rock into which the Idaho batholith was intruded. Armstrong, Taubeneck, and Hales (1977) observed an abrupt change in the initial $\mathrm{Sr}^{87} / \mathrm{sr}^{86}$ ratios in the plutonic rocks of Idaho, Washington, and Oregon. Their observation 
Table 5. Radiometric analysis of the quartz monzonite of the Idaho batholith along the Salmon River

Sample Location
(Keyed to Plate 5)
Material Analyzed
$\mathrm{Rb}$ (ppm)
$\mathrm{Sr}$ (ppm)
$\mathrm{Rb} / \mathrm{Sr}$
$\mathrm{Sr} 87 / \mathrm{Sr} 86$
$\mathrm{~K}-\mathrm{Ar}$

I

1

$\begin{array}{cc}\text { Blotite } & \text { Whole Rock } \\ 433 & 89 \\ 48 & 911 \\ 9.1 & 0.097 \\ 0.73780 & 0.70873 \\ 95 \pm 3 \mathrm{~m} . \mathrm{y} . & \end{array}$

4

$\begin{array}{ccc}\text { Biotite } & \text { Biotite } & \text { Biotite } \\ 65 & 11.7 & 111 \\ 1144 & 596 & 777 \\ 0.057 & 0.198 & 0.143 \\ 0.70926 & 0.70716 & 0.70864 \\ 79+2 \mathrm{~m} \cdot \mathrm{y} . & 82 \pm 2 \mathrm{~m} \cdot \mathrm{y} . & 79 \pm 2 \mathrm{~m} \cdot \mathrm{y} .\end{array}$

\author{
$78+4 m \cdot y \cdot$ \\ $\mathrm{m} \cdot \mathrm{y} \cdot=\mathrm{milli}$ on years \\ Froit: Axwostrong (1975, p. 38)
}


is that rocks with initial $\mathrm{Sr}^{87} / \mathrm{Sr}^{86}$ ratios below 0.7043 are intruded into Paleozoic or Mesozoic eugeosynclinal sediments, but rocks with initial $\mathrm{Sr}^{87} / \mathrm{Sr}^{86}$ ratios higher than 0.7055 are intruded into Precambrian basement rocks. Armstrong's (1975) values for the initial $\mathrm{sr}^{87} / \mathrm{sr}^{86}$ ratios of samples collected in and near the study area are between 0.70716 and 0.70926 . From these ratios it is to be inferred that the Idaho batholith in the study area intrudes Precambrian basement rocks which is contrary to our field observations. The textures and mineral assemblage indicate that the quartz monzonite is part of a mesozonal pluton.

The quartz monzonite was emplaced about $79+2.0$ million years ago during the late Cretaceous (Table 5). It should be noted that this age Is based on $\mathrm{X}-\mathrm{Ar}$ and $\mathrm{Rb}-\mathrm{Sr}$ dating methods; Armstrong (1975) notes that $\mathrm{Pb}-\mathrm{alpha}$ dates are uncertain because the inclusion of xenocrystic zircons in the rocks gives a date that is older than the actual age of the rock. 


\section{Arkoses and Tuffaceous Sandstones of Coal Creek}

The arkoses and tuffaceous sandstones of Coal Creek are divided into two units: a lower unit consisting of arkosic sandstones and conglomerates, and associated mudstones; and an upper unit consisting of tuffaceous sandstones and minor interbedded air-fall and ash-flow tuffs. Beds of the lower unit are found at the base of the Challis Volcanics. The most abundant exposures, after which the unit is named, are in the Coal Creek drainage in the northern half of sec. 16, T. $11 \mathrm{~N}$, , R. 14 E. Exposures of the lower unit are also found in East Basin Creek, Hay Creek, Basin Creek south of Duffey Creek 1 mile north of the confluence of Duffey and Basin Creeks, 500 feet southwest of Peak 8,449 and as a northwesttrending belt of outliers half-a-mile wide and several miles long found between the head of Coal Creek and the divide between Rankin Creek and Lower Hardin Creek. Exposures of the unft range from poor to fair; it is possible that the unit may not have been observed in other areas due to poor exposure.

Choate (1962) states that the contacts between the arkosic sedimentary rocks, the tuffaceous sandstones, and the lithic tuff at the base of the lava flows are gradational and that nowhere can the contact between rocks of dominantly sedimentary origin and rocks of dominantly volcanic origin be drawn. In actuality, the problem does not appear to be quite so serious. The top of the arkosic sediments (the lower unit of the arkoses and tuffaceous sandstones of Coal Creek) can be drawn at the top of the uppermost arkosic bed. Because the andesitic lithic tuff appears to be present below the lowermost andesite lava flow in most areas, whether 
the tuffaceous sandstones are present or not, the 1ithic tuff is included with the andesites of Bonanza Peak. Where rocks are present between the two boundaries just defined, they are dominantly water-laid sedimentary rocks derived largely from volcanic sources, but also they contain a certain amount of material derived from the plutonic rocks in the area. These arkosic beds have been designated as the lower unit of the arkoses and tuffaceous sandstones of Coal Creek. The volcaniclastic unit above the arkoses has been designated as the upper unit of the arkoses and tuffaceous sandstones of Coal Creek.

Thicknesses of the two units of the arkoses and tuffaceous sandstones of Coal Creek are highly variable. The maximum thickness of the lower arkosic unit is about 200 feet in sec. 16, T. $11 \mathrm{~N} ., \mathrm{R}, 14 \mathrm{E}$. The thickest exposures of the upper unit are in a block bounded on all four sides by faults; the block is in sec. 16, T. $11 \mathrm{~N} ., \mathrm{R}, 14 \mathrm{E}$. The unit exceeds 1,000 feet in thickness in this block; however, neither the top nor the bottom of the unit is exposed. In many places in the study area, either or both units of the arkoses and tuffaceous sandstones of Coal Creek are not present. This is probably due to the fact that the beds were only deposited in valleys on a quartz monzonite-floored erosion surface.

\section{Lower Unit}

The lower unit of the arkoses and tuffaceous sandstones of Coal Creek is composed of arkosic sandstones and conglomerates, and associated mudstones. The unit is found in small patches at the base of the Challis Volcanics or capping the tops of several ridges that mark a pre-Challisage erosional surface found at about 7,000 feet in the southeastern part of the study area. The unit, in general, is not well exposed. Artificial 
exposures produced by the mining and prospecting activity of the 1950 's are now largely concealed by land-sildes of soll and weathered rock. For this reason our observations of this unit were more restricted than those of Choate (1962) and Kern (1959).

The lower untt of the arkoses and tuffaceous sandstones of Coal Creek is the unit in which all of the sedimentary uranium deposits occur. In most areas, the uranium appears to be concentrated in the coarser stream gravels near the base of the unit. Although organic materfal is present in the unit, the uranium does not appear to show any preferential concentration in areas where the amount of visible organic material in the arkoses or the associated mudstones is high.

The contact between the arkosic sediments and the underlying quartz monzonites of the Idaho batholith is erosional. The arkosic conglomerates and sandstones were deposited in a high-energy fluvial environment that contained streams with flood plains, ponds, small lakes, and swamps. Choate (1962, p. 32) states that at least some of the stream channels followed a northwest trend which was possibly structurally controlled by pre-existing faults in the quartz monzonite that may have been active during the time the arkosic sediments were being deposited. The northwest trend of the channels could not be confirmed by us.

The contact between the upper and lower units of the arkoses and tuffaceous sandstones of Coal Creek appears to be unconformable based on differing attitudes between rocks of the two units. In places such as the Lucky Strike claim, in the NE $1 / 4 \mathrm{sec} .17, \mathrm{~T} .11 \mathrm{~N} ., \mathrm{R}, 14 \mathrm{E}$. where the arkoses are in contact with the andesites of Bonanza Peak, the dips of the two units are concordant; however, for these two units to be in contact with each other, the upper unit of the arkoses and tuffaceous sandstones 
of Coal Creek must be missing. In several places in sec. 16, T. $11 \mathrm{~N}$. , R. 14 E., the arkoses are in fault contact with the porphyritic quartz monzonites of the Idaho batholith.

The sandstones and conglomerates are light gray (N6) to grayish orange (10 YR 7/4) and weather to colors between pale grayish orange (10 YR 8/4) and pale yellowish brown (10 YR 6/2). Sand grains are angular to subangular and poorly sorted. The sandstone is composed of 40 to 45 percent quartz, 20 to 50 percent feldspar, 0 to 5 percent biotite, 5 to 30 percent clay matrix, and 0 to 5 percent calcite cement. The sandstones are coarse gralned.

The pebbles, cobbles and boulders found in the arkosic conglomerates are rounded, smooth, and faceted. These characteristics indicate that the clasts are the result of an earlier cycle of erosion. Among the rock types noted as pebbles in the arkosic conglomerates are the following: black quartzite, gray quartzite, massive white quartz, laminated fine-grained cherty arglllite, black shale, gray mudstone, aplite, arkosic sandstone, impure quartzite, carbonaceous fossil material, and some vesicular pumice. Quartzite is the most common material in the pebbles. The sandy matrix of the conglomerates is similar in compostion to the sandstones. The thin conglomerate bed south of Peak 8,449 in the northwest part of the study area is capped by a 3-inch thick bed of black chert of unknown origin.

The shales associated with the conglomerates and sandstones are generally thinly bedded and fissile. They are dark in color and commonly contain a high percentage of organic material. The shales are believed to have been overbank deposits of the same streams that deposited the sandstones and the conglomerates. 
In thin sections the sandstones are composed of 44 to 63 percent quartz, 15 to 20 percent potassium feldspar, 0 to 15 percent plagloclase, 0 to 20 percent rock fragments of quartz and feldspar, 0 to 2 percent each biotite and altered feldspar, 0 to 1 percent each muscovite, sphene and fron oxide, and 14 to 20 percent clay matrix or calcite cement. All the sandstones are coarse-grained and poorly sorted. The grains are from 0.3 to $0.4 \mathrm{~mm}$ in diameter and are subangular to subrounded. Table 6 gives the modal composition for the thin sections of the rocks from this unit.

The potassium feldspar grains are subangular to subrounded and are between 0.5 and 3.0 in diameter. The potassium feldspar present is usually microcline, but orthoclase is also present in some specimens. Some of the potassium feldspar grains are weathering to sericite.

The plagioclase feldspar grains are angular to subrounded. The grains range in diameter from 0.3 to $3.0 \mathrm{~mm}$. The plagloclase may be partially to almost completely weathered to sericite or replaced by calcite. In a few cases, the alteration is so complete that the feldspar can be 1dentified only tentatively as plagioclase.

The rock fragments are subangular to subrounded grains between 4.0 and $5.0 \mathrm{~mm}$ in diameter. They are generally composed of two or three crystals of quartz and feldspar.

Biotite occurs as light to dark brown pleochroic plates less than 1.0 mm in length and less than $0.5 \mathrm{~mm}$ in width that have been bent around the surrounding grains during compaction of the rock. Muscovite habit is similar to that of biotite, except that the grains are between 0.25 and 1.0 mm in length and the bending due to compaction is much less pronounced. 
Table 6. Modal composition of the lower unit of the arkoses and tuffaceous sandstones of Coal Creek.

Volume percent visually estimated from thin sections

\begin{tabular}{|c|c|c|c|c|}
\hline Sample Number & $8.27-2 B$ & $8.27-4 B$ & $9.18-3 B$ & $9.18 \mathrm{r}-4 \mathrm{~B}$ \\
\hline Rock Name & $\begin{array}{c}\text { Arkosic } \\
\text { sands tone }\end{array}$ & $\begin{array}{l}\text { Arkosic } \\
\text { sandstone }\end{array}$ & $\begin{array}{c}\text { Arkosic } \\
\text { sandstone }\end{array}$ & $\begin{array}{c}\text { Arkosic } \\
\text { granule } \\
\text { conglomerat }\end{array}$ \\
\hline Quartz & 44 & 50 & 63 & 45 \\
\hline Potassium feldspar & 15 & 15 & 20. & 20 \\
\hline Plagioclase & 15 & 3 & -- & -- \\
\hline Muscovite & trace & -- & trace & -- \\
\hline Biotite & -- & -- & -- & 1 \\
\hline $\begin{array}{l}\text { Calcite after } \\
\text { feldspar }\end{array}$ & -- & 2 & $\rightarrow$ & -- \\
\hline Rock fragments & -- & -- & -- & 20 \\
\hline Hematite & 1 & -- & - & -- \\
\hline Limonite & -- & -- & 1 & -- \\
\hline Clay matrix & 20 & 20 & 15 & 14 \\
\hline \multicolumn{5}{|c|}{ SAMPLE LOCATIONS } \\
\hline & $\begin{array}{l}8.27-2 \mathrm{~B} . \\
8.27-4 \mathrm{~B} . \\
9.18-3 \mathrm{~B} . \\
9.18-\mathrm{B} . \\
9.18-13 \mathrm{~B} .\end{array}$ & $\begin{array}{l}\mathrm{SE} 1 / 4 \mathrm{NW} 1 / 4 \mathrm{sec} . \\
\mathrm{SE} 1 / 4 \mathrm{NE} 1 / 4 \mathrm{sec} . \\
\mathrm{SE} 1 / 4 \mathrm{NE} 1 / 4 \mathrm{sec} . \\
\mathrm{SE} 1 / 4 \mathrm{NE} 1 / 4 \mathrm{sec} . \\
\mathrm{SE} 1 / 4 \mathrm{NW} 1 / 4 \mathrm{sec} .\end{array}$ & $\begin{array}{l}16, \mathrm{~T}, 11 \\
17, \mathrm{~T} .11 \\
16, \mathrm{~T}, 11 \\
16, \mathrm{~T}, 11 \\
16, \mathrm{~T}, 11\end{array}$ & $\begin{array}{ll}\text { N., R. } 14 \text { E. } \\
\text { N., R. } 14 \text { E. } \\
\text { N., R. } 14 \text { E. } \\
\text { N., R. } 14 \text { E. } \\
\text { N., R. } 14 \text { E. }\end{array}$ \\
\hline
\end{tabular}


The iron oxides are found mainly as patchy stains in the matrix of the rocks. Both limonite and hematite are found, though only one iron oxide is present in a given rock.

The matrix of the arkosic sandstones and conglomerates is composed of clay. In most of the thin sections examined, up to about 15 percent of the matrix had recrystallized to sericite. The matrix, in general, has sma11 irregular patches of iron staining. In some samples, the matrix also contains a certain amount (up to about 20 percent) of silt-size quartz grains.

Only minor amounts of pale brown calcite cement are present in most of the rocks. Where calcite is abundant, the clay matrix is subordinate or absent.

Carbonized plant remains are abundant in some thin beds and can occur in mudstones, arkosic sandstones and arkosic cobble conglomerates. No recognizable fossils are preserved in the lower unit of the arkoses and tuffaceous sandstones of Coal Creek.

Ten samples from the lower unit of the arkoses and tuffaceous sandstones of Coal Creek were analyzed for trace elements. The determinations are presented in Appendix table 2. Comparison of these analyses with those of the rocks of the Idaho batholith from which the arkoses were derived shows that most of the trace elements are about half as abundant in the arkoses as they are in the batholith rocks from which they are largely derived. The notable exception to this trend is the high concentration of manganese in the arkosic sedimentary rocks. Upper Unit

The upper unft of the arkoses and tuffaceous sandstones of Coal Creek 
is composed dominantly of tuffaceous sandstones, with interbedded mudstones and minor amounts of air-fall and ash-flow tuff. The rocks of this unit are found only in Coal Creek and Tick Creek in the northern half of sec. 16, T. 11 N., R. 14 E.; however, the unit does not form good outcrops and may have gone undetected in other areas. The unit ranges from a knife edge to in excess of 1,000 feet in thickness.

The tuffaceous sandstone unit has a gradational contact with the 1ithic tuff bed that underlies the andesites of Bonanza Peak in the NW $1 / 4$ sec. 16, T. $11 \mathrm{~N} .$, R. $14 \mathrm{E}$. Based on the differences in attitudes between the arkosic unit and the tuffaceous sandstone unit, it would appear that there is an unconformity between the lower and upper units of the arkoses and tuffaceous sandstones of Coal Creek. In the $\mathrm{N} 1 / 2 \mathrm{sec}$. I6, T. $11 \mathrm{~N}$. , R. 14 E., the tuffaceous sandstone unit is in fault contact with the porphyritic quartz monzonites of the Idaho batholith. The tuffaceous sandstone unit is also in fault contact with the arkosic unit and with the andesites of Bonanza Peak in the NW $1 / 4 \mathrm{sec}, 16, \mathrm{~T}, 11 \mathrm{~N},, \mathrm{R}, 14 \mathrm{E}$. It is possible that some of the faults between the tuffaceous sandstone unit and the underlying units may have been active during the deposition of the tuffaceous sandstone unit because the thickest exposures of the unit in the NE 1/4 sec. 16, T. 11 N., R. 14 E., are in fault-bounded blocks.

The rocks of the tuffaceous sandstone unit are pale olive (10 Y 6/2) to yellowish gray $(5 \mathrm{Y} 8 / 1$ ) and weather to colors between light brown (5 YR 5/4) and dark yellowish brown (10 YR 4/2). Iron oxides commonly stain the weathered surface of the rock. Sand grains in the unit are angular to subangular and are poorly sorted. The sandstones are composed of 5 to 20 percent quartz, 20 to 30 percent feldspar, 5 to 25 percent rock fragments, 
and 25 to 35 percent clay matrix, which contains a significant amount of altered volcanic glass. Sandstone beds range from a few inches to 3 feet in thickness.

The mudstones associated with the sandstones are extremely finegrained and contaln little coarse material. They contaln a large amount of clay that appears to have been derived from volcanic glass. The rocks may contain up to 20 percent carbonaceous plant material and, in some cases, well-preserved plant fossils. Mudstone beds range from a few inches to 6 feet in thickness. The mudstone is poorly consolidated and generally crumbles into small fragments.

The ash-flow tuffs associated with the tuffaceous sandstones generally differ from the associated sedimentary rocks in that the grains are much less rounded and the tuffs contain large, elongated pumice lumps. The ash-flow tuff beds are about 5 feet thick. The air-fall material differs from the sedimentary rocks in that the air-fall tuff contains a higher ratio of mineral crystals to rock fragments than the tuffaceous sandstones, and the air-fall tuff contains no calcite cement. The airfall tuff beds are about 1-foot thick. Although most of the sedimentary rocks of the tuffaceous sandstone unit are derived from andesitic tuffs and have not been transported far, it is thought that the amount of unreworked material in the unit is rather small and is confined mostly to the ash flows.

In thin sections, the tuffaceous sandstones are composed of 20 to 25 percent rock fragments, 10 to 20 percent plagioclase, 5 to 20 percent quartz, 0 to 2 percent potassium feldspar, 0 to 20 percent pumice, 0 to 35 percent glass lumps, 0 to 1 percent muscovite, 10 to 15 percent clay matrix, 
and 8 to 18 percent calcite cement. Most of the grains are subangular to subrounded, and the rocks are poorly to moderately sorted. Table 7 gives the modal composition for five representative rocks of this unit.

The rock fragments are dark, porphyrit1c volcanic rocks with aphanitic matrices. They are dominantly subrounded in shape, but range from subangular to subrounded. The groundmass of the rock fragments is partly altered to clay; plagioclase phenocrysts in some are altered in part to calcite. The rock fragments range from 0.2 to $1.5 \mathrm{~mm}$ in diameter, but most are less than $0.5 \mathrm{~mm}$ in diameter.

The plagioclase grains are generally angular to subangular; in most cases, they appear to have been euhedral lath-shaped crystals that have had their corners rounded slightly by transportation. There is a wide variation in the degree of alteration shown by the plagioclase grains, from partial to nearly complete replacement by calcite. Some grains show normal compositional zoning; these grains were probably derived from volcanic sources. The plagioclase grains range from 0.1 to $0.7 \mathrm{~mm}$ in width and from 0.2 to $1.0 \mathrm{~mm}$ in length.

The quartz grains range from angular to rounded in shape, but most are subrounded. They are 0.2 to $1.0 \mathrm{~mm}$ in diameter. Most of the quartz shows undulatory extinction, and some quartz grains contain inclusions of rutile, which suggest that at least some of the quartz in the tuffaceous sandstones was derived from the quartz monzonites of the Idaho batholith.

The potassium feldspar found in the tuffaceous sandstones is domInantly microcline. A few grains of sanidine are also present. The potassium feldspar grains are subangular to subrounded. They range in diameter from 0.2 to $0.3 \mathrm{~mm}$ and from 1.0 to $1.5 \mathrm{~mm}$ in width. There is 
Table 7. Modal composition of the upper unit of the arkoses and tuffaceous sandstones of Coal Creek

Volume percent visually estimated from thin sections

Sample Number

Rock Name

Quartz

Plagloclase

$\mathrm{K}$-feldspar

Rock fragments

Glass lumps

Pumice

Muscovite

Clay matrix

Calcite cement

Glass Shards

Sanidine

Blotite

Groundmass

Calcite after

plagloclase
8.06-1

8.06-2

8. 22-1

7.27-3A

$9.18-2 B$

Andesitic water-laid Volcaniclastic Tuffaceous Ash-flow tuff Air-fall tuff tuff sandstone sandstone

$\begin{array}{rrrrr}5 & 20 & 15 & -- & 10 \\ 15 & 10 & 5 & 25 & 25 \\ -- & 2 & 1 & -- & -- \\ 20 & 20 & 25 & -- & 10 \\ 35 & -- & -- & -- & -- \\ -- & -- & 20 & 25 & -- \\ -- & -- & 1 & -- & -- \\ 10 & 15 & 10 & -- & -- \\ 15 & 18 & 8 & -- & 5 \\ -- & -- & -- & 30 & 1 \\ -- & -- & -- & -- & 34 \\ -- & -- & -- & -- & --\end{array}$

SAMPLE LOCATIONS

8.06-1. NEcornerNW1/4 sec. 16, T. $11 \mathrm{~N} ., \mathrm{R}, 14 \mathrm{E}$.

8.06-2. NE1/4NW1/4 sec. $16, T .11 \mathrm{~N} .$, R. $14 \mathrm{E}$.

8.22-1. SW $1 / 4 \mathrm{NE} 1 / 4 \mathrm{sec} .16, \mathrm{~T} .11 \mathrm{~N} ., \mathrm{R} .14 \mathrm{E}$.

7.27-3A. SE1/4NE1/4 sec. 16, T. $11 \mathrm{~N} ., \mathrm{R}, 14 \mathrm{E}$.

9.18-2B. NE1/4NE1/4 sec. 16, T. 11 N., R. $14 \mathrm{E}$. 
a wide variation in the degree of alteration of the potassium feldspar grains, from fresh crystals to grains that are almost completely altered to clay.

The pumice occurs as rounded grains from 0.3 to $1.5 \mathrm{~mm}$ in diameter. The glass in the pumice has been devitrified to clay minerals. Calcite now fills the vesicles of the original pumice. The pumice can still be recognized by the fibrous structure of the grains. The detrital glass grains are rounded and are between 0.3 and $0.8 \mathrm{~mm}$ in diameter. The glass is devitrified to clay, which is a slightly different color from the clays in the matrix of the sandstone.

Muscovite is present as small platy grains between 0.2 and $0.25 \mathrm{~mm}$ wide and 0.2 and $1.0 \mathrm{~mm}$ long. Because muscovite is not present in the volcanic rocks of the area, the source of the muscovite would appear to be the quartz monzonites of the Idaho batholith.

The matrix of the tuffaceous sandstones is a greenish-brown clay. The material appears to be derived, at least in part, from the alteration of very finely divided volcanic glass that may have been deposited between the grains of the rock. Some clay material is also probably of depositional origin.

The calcite occurs as a cement distributed irregularly throughout the rock. The calcite is light brownish in color, apparently due to clay or iron oxide inclusions.

A few tuff beds are found interbedded with the mudstones and tuffaceous sandstones of the tuffaceous sandstone unit. The main differences between the tuffs and the tuffaceous sandstones are that the tuffs lack the clay matrix and calcite cement of the tuffaceous sandstones, the 
mineral components of possible Idaho batholith origin are missing, and glass shards are present, in some instances, in the tuffs. Thin sections were made of specimens representative of an ash-flow tuff that occurs near the top of the unit and of an air-fall tuff which occurs near the middle of the section. Table 7 gives the modal composition of these thin sections.

The ash-flow tuff consists of 30 percent glass shards, 25 percent pumice, 25 percent plagioclase, and 20 percent groundmass. The glass shards are thin, fairly small, bubble-wall fragments that are devitrified to cristobalite (?) and feldspar (?). Many of the shards are distorted in shape as if the rock had flowed while still hot. The glass shards are about $0.15 \mathrm{~mm}$ long and $0.05 \mathrm{~mm}$ wide. The pumice occurs as elongated, flattened streaks with irregular margins. The pumice lumps are between 0.5 and $1.5 \mathrm{~mm}$ in width and between 1.5 and $7.0 \mathrm{~mm}$ in length. The glass of the pumice lumps has devitrified to greenish-brown clay. The plagioclase occurs as euhedral to subhedral laths between 0.3 and $1.2 \mathrm{~mm}$ wide and between 1.5 and $3.0 \mathrm{~mm}$ 1ong. The composition of the plagioclase is about $\mathrm{An}_{56}$ and some of the crystals show normal compositional zonation. Most of the crystals show a patchy alteration to sericite. The groundmass is glass which has partially devitrified to either a combination of cristobalite (?) and feldspar (?), or to a greenish-brown clay.

The air-fall tuff is composed of 25 percent plagioclase, 15 percent pumice lumps, 10 percent quartz, 10 percent rock fragments, 5 percent sanidine, 1 percent biotite, and 34 percent groundmass. The plagioclase occurs as subhedral laths, of which about one-third are broken. The crystals range between 0.3 and $0.6 \mathrm{~mm}$ in diameter. The average composition of the plagioclase is about $\mathrm{An}_{43}$, and a few crystals show normal 
compositional zoning. The pumice lumps are between 0.25 and $0.5 \mathrm{~mm}$ in diameter and are between 0.75 and $2.0 \mathrm{~mm}$ long. The glass has been devitrified to clay. The quartz occurs as irregularly shaped or broken crystals between 0.2 and $0.6 \mathrm{~mm}$ in diameter. The rock fragments are grains of subrounded aphanitic volcanic rocks that are between 0.25 and $0.6 \mathrm{~mm}$ wide and between 0.7 and $1.5 \mathrm{~mm}$ long. The sanidine occurs as irregularly shaped or broken crystals about $0.2 \mathrm{~mm}$ in diameter. The biotite is partly altered to chlorite. The groundmass is glass that has devitrified to clay.

It is thought that the tuffs that are interbedded with the tuffaceous sandstones represent the type of material that was redeposited to form the tuffaceous sandstones. The material in the tuffaceous sandstones tends to be fine-grained, thereby indicating that the streams responsible for transporting the material were not particularly high in energy. The mudstones could have been deposited either in a body of standing water or in a somewhat swampy environment near a stream.

The trace element analyses for two samples from the upper unit of the arkoses and tuffaceous sandstones of Coal Creek are presented in Appendix table 2. The source rocks for the upper, tuffaceous sandstone unit of the arkoses and tuffaceous sandstones of Coal Creek are believed to be volcanic rocks of intermediate origin similar to the tuffs that accompanied the voluminous eruptions of andesite and dacite lavas which make up the andesites of Bonanza Peak and that closely followed upon the deposition of the Coal Creek unit. Comparison of the trace element analyses for the two units supports this assumption. The patterns of trace element distribution in both rock units are similar and most of 
the trace elements are present in about equal abundances in the two units. Notable exceptions are the lower abundances of chromium, cobalt, nickel, and copper in the tuffaceous sandstones. 


\section{Andesite of Bonanza Peak}

The andesite of Bonanza Peak ( $\mathrm{Ta}$ ) is composed of undifferentiated porphyritic to aphanitic andesite, dacite, and rhyodacite lava flows and flow breccias. Thin interbeds of tuffs, volcaniclastic and tuffaceous sandstones, and laharic brecclas occur throughout the unit, and these interbeds become thicker and more common towards the top of the unit. This unit, commonly, is the lowermost layered Challis volcanic unit found in the region as it oversteps the Coal Creek unit to Ile directly upon the Idaho batholith and Paleozoic rocks. It is the thickest volcanic unit, with a maximum thickness of 5,000 feet in the Bonanza Peak area. These lava flows may be correlated with the andesite lava flows described by Cass (1973), Brolli (1974), and the upper sequence of andesite rocks mapped by Stiles (1976). The ash flows are quartz latite In petrographic composition. Air-fall tuffs are identified in hand specimen as dacite to quartz latite in composition, although petrographically they are quartz latite. The untt is composed dominantly of lava flows with the remainder being discontinuous interbeds of pyroclastic air-fall, lapill1, and water-laid tuffs; and some laharic breccias.

The andesite of Bonanza Peak crops out mainly as cliffs that are commonly 30 to 100 feet high. These cliffs are formed of andesite to rhyodacite flows; elsewhere the andesite unit underlies well-rounded, soil-covered slopes which form on interbeds of tuff and flow-top breccias.

The regional attitude of the unit is $\mathrm{N}$. $35-40^{\circ} \mathrm{E}$. , dipping 15 to $45^{\circ} \mathrm{S}$. Locally, the attitude of the unit is variable as a result of 
the faulting that accompanied the development of a northeast-trending graben structure and volcano-tectonic subsidence. Late-stage doming, a1so, may have had some local effect upon the attitude of the unit. Near the base of the unit, the interbeds are from 1 to 3 feet thick, while near the top the interbeds are greater than 10-feet thick. In a few instances, the tuffs crop out as distinct mappable units which are discussed separately.

The flow contacts appear to be planar with some undulations which would be expected when a flow overrides another older and slightly eroded flow. The contacts, in general, are distinct with flow-top breccias up to 10 feet thick, and are abruptly surmounted by the next lava flow. The total number of lava flows is unknown but there are over 30 flows on the lower slopes of Bonanza Peak. The flow-top breccias are light gray (N7) and are formed of lapilli-sized angular fragments of the underlying flow.

The quartz latite tuff interbeds vary from a grayish orange pink (5 YR 7/2), well-indurated, crystal-vitric quartz latite air-fal1 tuff to a grayish-orange (10 $\mathrm{HR} 7 / 4)$, slightly welded, quartz latite ashflow tuff. The phenocrysts are from 1 to $3 \mathrm{~mm}$ in length and consist generally of plagioclase, biotite, quartz, and sanidine. Slightly flattened lumps of pumice, 5 to $15 \mathrm{~cm}$ in diameter, are aligned to the pyroclastic-flow contacts.

The rocks of the andesite of Bonanza Peak range from light brownish gray (5 YR 6/1) to olive black (5 Y 2/1) on fresh surfaces and weather to colors between grayish brown (5 YR 3/2) and dark yellowish brown $(10 \mathrm{YR} 3 / 2)$. The rocks are aphanitic porphyritic, with 5 to 20 percent 
phenocrysts visible in hand specimens. The phenocryst composition is 40 to 100 percent plagioclase, 0 to 10 percent sanidine, 0 to 15 percent quartz, and 0 to 35 percent biotite. Light-gray (N7) plagioclase phenocrysts range from 1 to $5 \mathrm{~mm}$ in length and make up between 0 to 20 percent of the rock. Although the dominant rock type appears to be andesite in hand specimen in thin sections, dacites and rhyodacites are equally common. There seems to be a tendency for the more silicic rock types to be more common higher in the section.

Table 8 shows the visually estimated mineral percentages observed in the andesite of Bonanza Peak. The rocks are holocrystalline with finegrained phenocrysts set in a microcrystalline matrix of devitrified glass and aligned microlites. The phenocrysts have the following characteristics.

The plagloclase occurs as euhedral to subhedral laths which range from 0.5 to $2.7 \mathrm{~mm}$ in length and from 0.2 to $1.2 \mathrm{~mm}$ in width. The crystals show albite twinning and rare Carlsbad twinning. A few crystals have normal compositional zonation. The composition of the plagioclase ranges from $\mathrm{An}_{35}$ to $\mathrm{An}_{70}$, with the average for the unit being approximately $\mathrm{An}_{50^{\circ}}$. The plagioclase is altered slightly, to almost completely to sericite, or, in some specimens, is partially replaced by calcite. Hypersthene occurs as euhedral to subhedral prismatic crystals with square cross-sections. The prisms are about 0.5 to $3.0 \mathrm{~mm}$ long and 0.2 to $1.5 \mathrm{~mm}$ wide. Hypersthene is present in almost half of the thin sections examined.

Augite occurs as euhedral to subhedral, prismatic laths and stubby prisms. It is colorless to very pale green and non-pleochrolc. The crystals are between 0.2 and $0.75 \mathrm{~mm}$ wide and 0.3 to $2.0 \mathrm{~mm}$ long. Augite is 
Table 8. Modal compositions of the andesite of Bonanza Peak

Volume percent visually estimated from thin sections

\begin{tabular}{|c|c|c|c|c|c|c|c|c|c|c|c|c|}
\hline Sample Number & 1 & 13 & 23 & 53 & 63 & 77 & 85 & 102 & 214 & 216 & 219 & 226 \\
\hline Rock Name & Andesite & Andesite & Dacite & Rhyodacite & Andesite & Andesite & Rhyodacite & Dacite & Dacite & Andesite & Rhyodacite & Dacit \\
\hline Plagioclase & 29 & 20 & 18 & 8 & 28 & 27 & 23 & 19 & 25 & 28 & 18 & 6 \\
\hline Hornblende & -- & trace & 2 & 12 & 4 & - & 8 & 10 & -- & -- & 3 & 4 \\
\hline Biotite & 6 & 6 & 6 & 3 & 4 & 6 & 3 & 3 & 8 & 4 & 12 & 2 \\
\hline Augite & 8 & 7 & 8 & - & 3 & 7 & -- & 3 & 6 & 8 & -- & -- \\
\hline Hypers thene & trace & -- & -- & -- & 2 & 2 & 2 & -- & -- & 7 & -- & -- \\
\hline Pigeonite & -- & 3 & - & -- & - & -- & -- & -- & 3 & -- & -- & -- \\
\hline Quartz & 4 & 2 & 2 & 7 & 2 & 2 & 8 & 7 & 9 & -- & 5 & -- \\
\hline Magnetite & 2 & 2 & 2 & 1 & 4 & 3 & 3 & 4 & 3 & 3 & 1 & 8 \\
\hline Ilmenite & trace & -- & 1 & -- & -- & trace & 1 & 1 & 2 & -- & -- & -- \\
\hline Groundmass & $5 I$ & 60 & 61 & 69 & 53 & 53 & 52 & 53 & 35 & 50 & 61 & 80 \\
\hline Carbonates & -- & -- & -- & -- & -- & -- & -- & -- & -- & -- & -- & -- \\
\hline Sanidine & -- & - & - & -- & -- & -- & -- & -- & -- & -- & -- & -- \\
\hline
\end{tabular}

* Analyzed for trace elements

** Analyzed for trace elements and major oxides 
Table 8. continued; Modal compositions of the andesite of Bonanza Peak

Volume percent visually estimated from thin sections

\begin{tabular}{|c|c|c|c|c|c|c|c|c|}
\hline Sample Number & $\mathrm{LF}-3$ & $L F-9$ & MAS665* & MAS668* & $\operatorname{MAS} 667 *$ & $L F-14$ & LF-17 & 63012 \\
\hline Rock Name & Andesice & Andesite & Dacite & Andesite & Andesite & Dacite & Dacite & Andesite \\
\hline Plagioclase & 60 & 40 & 60 & 70 & 40 & 60 & 25 & 10 \\
\hline Hornblende & -- & -- & -- & -- & -- & -- & trace & trace \\
\hline Biotite & -- & -- & -- & -- & -- & -- & -- & -- \\
\hline Augite & -- & -- & -- & -- & -- & -- & -- & 15 \\
\hline Hypers thene & -- & -- & -- & -- & -- & -- & -- & -- \\
\hline Pigeonite & 15 & 20 & -- & 15 & 30 & -- & 15 & -- \\
\hline Quartz & -- & -- & -- & -- & -- & -- & -- & -- \\
\hline Magnetite & trace & -- & 1 & 3 & 3 & 3 & 3 & 14 \\
\hline Ilmenite & -- & -- & -- & -- & -- & -- & -- & -- \\
\hline Groundmass & 25 & 40 & 40 & 10 & 20 & 25 & 60 & 61 \\
\hline Carbonates & -- & -- & trace & -- & trace & 10 & trace & -- \\
\hline Sanidine & -- & -- & -- & -- & -- & -- & - & -- \\
\hline
\end{tabular}

* Analyzed for trace elements

** Analyzed for trace elements and major oxides 
Table 8. continued; Modal compositions of the andesite of Bonanza Peak

Volume percent visually estimated from thin sections

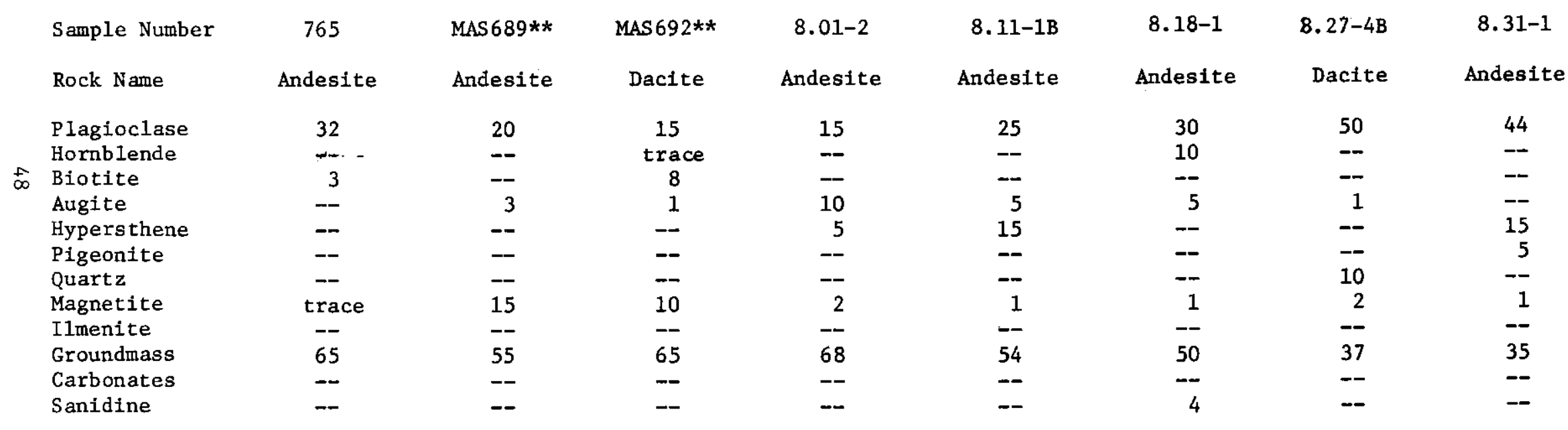

* Analyzed for trace elements

** Analyzed for trace elements and major oxides 
Table 8. continued; Modal compositions of the andesite of Bonanza Peak

SAMPLE LOCATIONS

1. Peak 7,260 feet in the eastern part of the study area.

13. 1,500 feet south of peak 7,260 feet in the eastern part.

23. 2,000 feet south of the West Fork Campground in the eastern part.

53. 1,000 feet west of the Sawmill Creek West Fork confluence in the eastern part.

63. 1,000 feet west of peak 7,260 in the eastern part.

77. Peak 8,051 feet in the north-central part.

85. 2,500 feet west of the Deadwood Creek-West Fork confluence in the north-central part.

102. 1,000 feet east of peak 7,722 feet in the north-central part.

214. 3,000 feet north of peak 7,424 feet in the southern-most part.

216. 2,500 feet west of West Fork Campground in the south-central part.

219. 500 feet south of the Deadwood Creek-West Fork confluence.

226. 1,000 feet south of peak 8,641 feet in the southeastern-most part.

LF-3. 3,100 feet east of peak 7552 .

LF-9. 5,000 feet west of peak 8218 .

MAS665. See plate 4.

MAS668. See plate 4.

MAS667. See plate 4.

LF-14. 2,000 feet north of peak 8317 .

LF-17. On peak 7723.

b3012. Head of Coal Creek.

765. On divide between East Basin, Coal, and Upper Hardin Creeks.

MAS689. See plate 4.

MAS692. See plate 4.

8.01-2. NW1/4NE1/4 sec. 4, T. 11 N., R. 14 E.

8.11-1B. SWI $/ 4$ SEl $/ 4$ sec. 5, T. 11 N., R. 14 E.

8.18-1. CenterSE1/4 sec. 5, T. $11 \mathrm{~N}$., R. $14 \mathrm{E}$.

8.27-4B. SEl/4NE1/4 sec. 16, T. $11 \mathrm{~N} .$, R. $14 \mathrm{E}$.

8.31-1. NW1/4SE1/4 sec. 5, T. 11 N., R. 14 E. 
found in over half of the thin sections examined and, in some, is associated with hypersthene.

Pigeonite occurs as subhedral, very pale green crystals with a low $2 \mathrm{~V}$ angle. The crystals are 0.2 to $0.5 \mathrm{~mm}$ wide and 0.3 to $1.2 \mathrm{~mm}$ long. Hornblende occurs as euhedral to subhedral prisms and as diamondshaped cross-sections. It is green to brown and pleochroic. The prisms range between 0.3 and $0.6 \mathrm{~mm}$ in length and between 0.2 and $0.3 \mathrm{~mm}$ in width. Hornblende is not as common as the pyroxenes or biotite.

Sanidine occurs as euhedral to subhedral laths with Carlsbad twinning. The sanidine crystals are much less altered to sericite than the plagioclase in the same rock. The sanidine crystals are from 0.5 to 1.0 mn long and from 0.25 to $0.5 \mathrm{~mm}$ wide. Sanidine is rarely present in this unit.

Quartz occurs in about half of the thin sections as small irregularly shaped crystals $0.1 \mathrm{~mm}$ or less in diameter.

Magnetite occurs as subhedral opaque grains that are silver-black in reflected light. The crystals are between 0.01 and $0.2 \mathrm{~mm}$ in diameter. Some of the crystals are partly weathered to hematite.

The groundmass of the andesites is hypocrystalline and is composed of 25 to 60 percent feldspar laths, 38 to 73 percent yellowish-brown clay material (saponite?) formed by the alteration of glass, and about 2 percent very fine-grained opaque material (magnetite?). The feldspar laths in the matrix are between 0.02 and $0.15 \mathrm{~mm}$ in length.

The basal part of the andesite of Bonanza Peak in the thesis area is a lithic andesitic tuff that ranges between about 5 and 40 feet in thickness. The tuff is composed of about 45 percent rock fragments, 20 percent 
plagioclase, 10 percent quartz, 2 percent blotite, 2 percent devitrified glass shards (?), 1 percent iron oxides, and 30 percent groundmass. The rock fragments are subrounded and between 0.3 and $0.5 \mathrm{~mm}$ in diameter. They are extremely fine-grained volcanic rocks composed of varying proportions of quartz, plagloclase, and devitrified glass. Plagioclase crystals are euhedral to subhedral laths, sometimes rounded, about $0.25 \mathrm{~mm}$ in diameter. The plagioclase is slightly to almost completely altered to serlcite or replaced by calcite. The quartz occurs as broken or subhedral crystals between 0.1 and $0.25 \mathrm{~mm}$ in diameter. The blotite is light to dark reddish-brown and occurs as pleochrolc crystals about $0.25 \mathrm{~mm}$ long. The glass shards (?) are devitrified to a greenish-brown clay material that grows radially 1nward from what appears to have been the margins of the shards. The shards (?) are about $0.15 \mathrm{~mm}$ in length. The iron oxides occur as reddish material staining the groundmass. The groundmass is greenishbrown clay that probably formed by the devitrification of volcanic glass.

The interbeds in the andesite of Bonanza Peak are dominantly lithiccrystal-vitric ash-flow tuffs of andesitic composition and with an eutaxitic structure. All interbeds in the area are poorly exposed, and most could not be traced for more than a few feet. The interbeds are composed of 10 to 15 percent rock fragments, 10 to 20 percent plagioclase, 5 percent sanidine, 15 percent pumice, 25 percent glass shards and 20 to 35 percent groundmass (see table 9). The rock fragments are angular to rounded grains of dominantly dark, fine-grained volcanic rocks. They are between 0.5 and $2.0 \mathrm{~mm}$ wide and between 1.0 and $4.0 \mathrm{~mm}$ long. The plagioclase occurs as euhedral to subhedral, or broken, crystals. Albite twins are generally poorly developed, but the grains show moderate to strongly 
developed normal compositional zonation. A plagioclase composition of $\mathrm{An}_{37}$ was determined for one rock. The plagioclase crystals are between 0.3 and $2.0 \mathrm{~mm}$ wide and between 0.5 and $3.5 \mathrm{~mm}$ long. Some of the plagioclase is altered to sericite. The sanidine occurs as subhedral or broken crystals between 0.3 and $0.7 \mathrm{~mm}$ wide and between 0.5 and $3.0 \mathrm{~mm}$ long. The pumice occurs as elongated patches with irregular boundaries. The patches are between 0.2 and $4.5 \mathrm{~mm}$ in width and between 2.0 and $11.5 \mathrm{~mm}$ in length. The pumice is devitrified to a pale-green clay. The glass shards are bubble-wall fragments with irregular, curved, or triangular shapes between 0.02 and $0.05 \mathrm{~mm}$ wide and between 0.15 and $0.03 \mathrm{~mm}$ long. They are devitrified to a fibrous aggregate of tridymite (?), cristobalite and feldspar, with minor associated clay. The groundmass is glass that has devitrified to a pale-green or greenish-yellow clay.

The chemical analyses and the calculated normative minerals for the lava flows of the andesite of Bonanza Peak are presented in Appendix table 1. When these rocks are compared with analyses listed in Carmichael, Turner, and Verhoogen (1974), it is seen that their overall chemical composition is similar to andesites found in other parts of the world. The major differences appear to be that the $\mathrm{Al}_{2} \mathrm{O}_{3}$ and $\mathrm{K}_{2} \mathrm{O}$ content of some $\mathrm{nf}$ the samples of the andesite of Bonanza Peak is slightly lower than average.

The trace element abundances for the andesite of Bonanza Peak are given in Appendix table 2. When compared with the analyses of Jakes and White (1972) or with Taylor and others (1962), it appears that the andesite of Bonanza Peak is similar in trace element content to andesites found elsewhere in the world, although barium and chromium have noticeably higher concentrations. 
Twenty-five paleomagnetic measurements of polarity on lava flows belonging to the andesites of Bonanza Peak (see plate 5) indicate that the flows are of normal polarity and that there are no magnetic reversals. The normal polarities suggest that the thick sequence of lava flows was extruded in a short period of time. Two age determinations of $47.3+1.4 \mathrm{~m} . \mathrm{y}$. and $45.6 \pm 1.4 \mathrm{~m} . \mathrm{y}$. are from andesites that we correlate with the andesites of Bonanza Peak (Armstrong, 1975). Periods of normal polarity with the period from 48.8 to $44.2 \mathrm{~m} . \mathrm{y}$. are all less than 1 million years according to the data of Tarling and Mitchell (1976). One million years then represents the maximum time of eruption of the andesite flows.

The andesite of Bonanza Peak lies unconformably below the tuff of Duffey Creek. The lower contact is most1y unconformable, with the andesite of Bonanza Peak lying variably on either the upper or the lower unit of the arkoses and tuffaceous sandstones of Coal Creek or, more commonly, on the intrusive rocks of the Idaho batholith. Where the andesites of Bonanza Peak are in contact with the upper unit of the arkoses and tuffaceous sandstones of Coal Creek, the contact is gradational between the tuffaceous sandstones and the basal tuff unit of the andesite of Bonanza Peak. The contact between the andesite of Bonanza Peak and the lower unit of the arkoses and tuffaceous sandstones of Coal Creek on East Basin Creek is unconformable. In general, there are fault contacts between the andesites of Bonanza Peak and the quartz monzonite of the Idaho batholith. In some places this contact is an unconformity.

The base of the andesite of Bonanza Peak occurs at varying elevations, even when not faulted; this difference in elevation indicates that the lava flows were extruded over rolling terrain, which had valleys with streams that earlier had deposited the conglomeratic arkoses. Rhyodacite water- 
Table 9. Modal composition of the tuff interbeds and basal tuff of the andesite of Bonanza Peak

Volume percent visually estimated from thin sections

Sample Number
Rock Name
Quartz
Plagioclase
Sanidine
Biotite
Rock fragments
Pumice
Glass shards
Groundmass

$8.06-1 \mathrm{~B}$
Lithic-crysta
dacite tuff
30
10
trace
trace
43
1
--
15

$8.11-8$

$9.11-2$

$\begin{array}{cl}\text { Lithic-crystal } & \text { Crystal-lithic } \\ \text { dacite tuff } & \text { andesite tuff }\end{array}$

Crystal-lithic $\overline{20}$

5

$--$

15

15

25

20
Vitric-crystal andesite tuff

\section{SAMPLE LOCATIONS}

8.06-1B. Basal tuff, NE corner NW $1 / 4 \mathrm{sec}, 16, T .11 \mathrm{~N} .$, R. 14 E. 8.11-8. Interbedded tuff, NW $1 / 4 \mathrm{SE} 1 / 4 \mathrm{sec} .5, \mathrm{~T} .11 \mathrm{~N} ., \mathrm{R} .14 \mathrm{E}$.

9.11-2. Interbedded tuff, SE $1 / 4 \mathrm{NW} 1 / 4$ sec. 4, T. $11 \mathrm{~N} .$, R. $14 \mathrm{E}$. 
laid tuffs, andesitic laharic breccias, and brecciated andesite flows that contain red cherts indicate that the environment was wet and numerous lakes probably were scattered throughout the landscape after each volcanic episode.

\section{Rhyodacite Water-1aid Tuff}

The rhyodacite water-1aid tuff is found in two lacalities within the outcrop area of the andesites of Bonanza Peak. The first locality is 3 miles up East Basin Creek and the tuff underlies an area of several acres. The second is at the head of Silver Creek. The water-laid tuff is of sufficient thickness and aerial extent to warrant separation as a geologic sub-unit within the andesites of Bonanza Peak. The tuff only crops out along stream banks, and otherwise is covered by andesite float and soil so that a flat bench or terrace is the only indication of its presence.

The outcrops consist of bedded volcanic sandstones and siltstones composed of rhyodacite tuff. Some minor conglomerates and laharic breccias also occur. The water-laid tuff is generally light olive gray ( $5 \mathrm{Y} 6 / 1$ ), laminated, crossbedded, and moderate- to we11-indurated and sorted. The volcanic siltstones form thin ledges from 6 inches to 3 feet in thickness in the outcrops. The sandstones are not quite as well indurated so that they form small benches from 6 inches to 2 feet in thickness. Thin $1-$ to 2 foot beds of a pebble conglomerate composed of rounded andesite clasts in a volcanic sand matrix are found interfingering in the sandstones. Thin 10-foot interbeds of greenish-gray (5 GY 6/1) laharic breccias are formed of 50 percent subrounded andesite cobbles in a matrix of convoluted beds of volcanic siltstones and sandstones. The entire unit does not exceed 100 feet in thickness. 
Three thin sections of the volcanic sandstones are visually estimated to contain, on an average, 25 percent plagioclase $\left(\mathrm{An}_{45}\right), 15$ percent sanidine, 1 percent quartz, 5 percent biotite, 5 percent hornblende, 3 percent opaques, 35 percent felsophyric groundmass of glass, kaolinfte, calcite, and 15 percent fragments of biotite andesite. The minerals are similar in appearance to those described from the andesite flows with the exception that the grains are subrounded rather than subhedral.

Two thin sections from the matrix of the laharic breccias have the same appearance as the sandstones previously discussed. The andesite clasts are cobble- to boulder-sized with the cobbles being the domInant size class. Appendix table 2 gives the trace element concentrations that were determined from this unit. The tuffs are not appreciably different from the andesite with respect to trace element concentrations. This similarity is expected because the tuffs are derived from the andesite and related interbeds.

The rhyodacite tuffs are both underlain and overlain by the andesite flows. Contacts are covered by debris from the overlying rocks and their positions can only be inferred. The rhyodacite water-laid tuff on East Basin Creek is overlain partly by the quartz latite of East Basin Creek, which itself is an interbed in the andesite.

The tuffs were deposited in shallow lakes by fluvial processes that eroded the local volcanic ashes and andesite flows. The lakes were probably formed when flows of andesite temporarily blocked stream drainages. Crossbedding in the bedded volcanic sandstones of East Basin Creek indicates that the streams were flowing to the south. 
Quartz Latite of East Basin Creek

This ash-flow lies conformably between two lava flows in the upper part of the andesite of Bonanza Peak. It is overlain by at least 800 feet of andesitic lava flows. This tuff is exposed in the central part of the study area (p1. 1). Outcrops are sparse and small, and this unit is generally a slope former. This unit lacks any sort of distinctive joint system. Most geologic mapping of the quartz latite was done from float found on the surface and in the soil.

This tuff appears to be a single ash flow which is about 200 feet thick. The average strike of this unit is $\mathrm{N} .40^{\circ} \mathrm{E}$. with a southeasterly dip of about $20^{\circ}$. This attitude is concordant with the tops and bottoms of the associated 1ava flows. Some rounded to sub-rounded xenoliths, up to 6 inches in diameter, of andesite composition occur and commonly weather out of the ash-flow and remain as float on the surface and in the soil. The ash-flow tuff is crystal-rich and greenish gray (5 GY 6/1). The basal portion, about 10 feet, is a much darker green than the remainder of the rock.

Table 10 shows the modal composition of a sample from the unit. Petrographic studies show that this unit is composed of a crystal-vitric quartz latite ash-flow tuff. Phenocrysts constitute about 35 percent of the rock, and at least 60 percent of these crystals are broken. Pumice and lithic fragments are present in about equal amounts for a combined sum of 10 percent. Glass shards are well preserved and constitute about 15 percent of the rock. The remaining portion is comprised of a clay and devitrified glassy matrix. Sanidine comprises about 35 percent of the phenocryst content. It is generally subhedral to anhedral and ranges 
Table 10. Modal composition of the quartz latite of East Basin Creek

Volume percent visually estimated from thin sections
\begin{tabular}{lc} 
Sample Number & $8.24-1$ \\
Rock Name & Ash-flow tuff \\
& 5 \\
Quartz & 20 \\
Plagioclase & 5 \\
Sanidine & 5 \\
Biotite & trace \\
Magnetite & 10 \\
Pumice lump & 55 \\
Vitric ground mass & \\
\multicolumn{2}{c}{ SAMPLE LOCATION }
\end{tabular}

8.24-1. One-half mile N. of NE corner sec. 4, T. 11 N., R. 14 E. 
from 0.2 to $1.8 \mathrm{~mm}$ in size. These crystals commonly show partial alteration to sericite, and montmorillonite (?). About 70 percent of these crystals are broken.

Plagioclase is present as andesine (An 34-38), and it comprises about 30 percent of the phenocryst content. Crystals are generally subhedral to anhedral and range from 0.2 to $2.2 \mathrm{~mm}$ in size. The cores of these phenocrysts are commonly altered to calcite. About 75 percent of these crystals are broken.

Quartz is present in amounts up to 20 percent of the phenocrysts. It is subhedral to anhedral and ranges in size from 0.1 to $1.5 \mathrm{~mm}$. Most of the quartz appears to be of primary origin and is corroded by the groundmass.

Accessory minerals include zircon and magnetite. Pumice fragments show light to moderate compaction and are generally devitrified. Glass shards are unaltered and show little to no compaction. Quartz is a common secondary mineral. Table 15 shows the trace element concentrations that occur in this unit. The ash-flow tuffs do not have appreciably different trace element concentrations from the surrounding andesite. Quartz Latite Lapil11 Tuff

The quartz latite lapilly tuff is a pyroclastic tuff found in a small area on the saddle between peaks 9,326 and 8,731 near Bonanza Peak. The unit appears to strike W. $20^{\circ} \mathrm{W}$. and dip $20^{\circ} \mathrm{E}$., which is similar to the attitude of the surrounding flows. The lapilli tuffs weather into slopes except for a cliff formed by a small fault on the unit's west side. The quartz latite lapilli tuff is pale green (5 G 7/2) when unweathered and contains pebble - to boulder-sized clasts of andesite. 
The pebble-sized clasts make up 75 to 80 percent of the rock and are composed of fragments of pumice from $5 \mathrm{~mm}$ to $30 \mathrm{~mm}$ in diameter, fragments of quartz latite pyroclastic tuff, and clasts of andesite. The cobblesized clasts are andesite fragments from 64 to $120 \mathrm{~mm}$ in diameter. The unit is probably the result of one pyroclastic episode and has a maximum thickness of 90 feet.

One thin section of the quartz latite lapilli tuff was examined. The section reveals that the tuff is hypocrystalline with a glassy matrix surrounding the rock and tuff fragments. The tuff fragments contain subhedral phenocrysts of plagioclase, quartz, sanidine, and biotite $0.7 \mathrm{~mm}$ to $1.2 \mathrm{~mm}$ in size.

The unit is visually estimated to contain 5 to 10 percent andesite fragments; 10 to 15 percent pumice; 30 to 40 percent ash-flow tuff fragments that contain 20 percent plagioclase, 3 percent sanidine, 10 percent quartz, and 5 percent biotite; and 30 percent matrix. The unit is slightly compacted and the phenocrysts have the same physical properties discussed in the section on the andesite of Bonanza Peak.

Table 15 shows the trace element concentrations that occur in this unit. The lapilli tuff is not appreciably different from the andesite with respect to the trace element concentrations.

The unit is an interbed of the andesite of Bonanza Peak. The contacts are obscured by float from the overlying rocks and can only be inferred. 


\section{Andesite of Deadwood Creek}

This unit is composed of undifferentiated andesite lava flows with interbedded thin, white air-fall tuffs. Individual lava flows range from 5 to 50 feet in thickness. The air-fall tuffs are generally less than 5 feet thick. The entire unit is at least 1,200 feet thick, and it conformably overlies the andesite of Bonanza Peak. The andesites of Deadwood Creek are distinguished from the andesites of Bonanza Peak by their more mafic character.

The general attitude of the andesites of Deadwood Creek is N. $40^{\circ}$ E., with a northwesterly dip of about $25^{\circ}$. To the south of this andesite unit, a major fault trends east-northeast through the Deadwood drainage basin. Along this fault, the rhyolitic tuffs and domes have been downdropped relative to the andesite of Deadwood Creek. On the northwest border of the unit, there is another major fault that downthrows the tuff of Duffey Creek against the andesite.

Outcrops of this andesite unit are abundant on southerly exposed slopes; but are sparse on north-facing slopes.

The interbedded air-fall tuffs are seldom exposed. They are thin and generally are observed as float on the surface and in the soil.

In hand specimen, the andesites are dusky yellow brown when fresh, and weather to a grayish brown (5 YR 3/2). Petrographic studies of five thin sections show plagioclase to be the most abundant mineral present in amounts from 35 to 40 percent of the entire rock. Plagioclase is present as laths of labradorite (An 52-64) which range in size from 0.3 to $2.8 \mathrm{~mm}$. These laths are randomly oriented in each thin section studied. 
Augite comprises from 12 to 15 percent of the rock and is the only pyroxene mineral present. These phenocrysts are euhedral to subhedral and range from 0.3 to $1.5 \mathrm{~mm}$ in size. Some crystals have faint twin planes, but these are rather uncommon. Biotite is present in amounts from 7 to 10 percent. It is generally less than $0.3 \mathrm{~mm}$ in size and weakly pleochroic. These crystals are generally subhedral and disseminated within the groundmass.

Ilmenite comprises 5 to $\delta$ percent of the entire rock. It generally occurs as randomly oriented, acicular crystals which are usually less than $1.0 \mathrm{~mm}$ in 1ength. Iddingsite consitutes about 2 percent of the rock, and is an alteration product of olivine.

The groundmass comprises from 25 to 30 percent of the entire rock. Some potassium feldspar in the groundmass is indicated by staining with sodium colbaltinitrate.

No thin sections were made of the air-fall tuffs. In hand specimen, these rocks are very fine grained and white to buff colored. Phenocrysts of quartz constitute 10 to 15 percent of the rock; the remainder is glass and clay.

The major oxide analyses for the andesites of Deadwood Creek are presented on Appendix table 1 and the trace element analyses on Appendix table 2 . 


\section{Tuff of Duffey Creek}

On the upper slopes at the heads of the valleys of Duffey Creek and Basin Creek lies a 1,000 foot thick sequence of interbedded air-fall tuffs, water laid-tuffs, laharic breccias, conglomerates, and tuffaceous sandstones, named here the tuff of Duffey Creek which lies stratigraphically above the andesite of Bonanza Peak. The lower contact with the andesite of Bonanza Peak is gradational and is arbitrarily chosen as the top of the uppermost andesite lava flow. The upper contact of the tuff is not present in the study area. The unit appears to unconformably overlie the andesite of Bonanza Peak in some areas, while in other areas the tuff and andesite are conformable.

The best exposure of the tuffaceous sandstones and volcaniclastic conglomerates is 1,500 feet northwest of peak 9,003 on a cliff face. The lowest bed is a white (N9) rhyolite vitric tuff of unknown thickness because the base is not exposed. The air-fall tuff changes gradationally up the section into a laminated water-1aid tuff and tuffaceous sandstones and mudstones (see table 11). The water-laid tuffs have been intruded by an obsidian dome which has silicified the alternating layers of tuffaceous sandstone and mudstone. The upper part of this section is obscure because of intrusions of rhyolite sills and the obsidian dome.

The lower portion of the tuff of Duffey Creek largely represents andesite debris eroded from the volcanic rocks to the north by mudflows and streams. The volcanic conglomerates were probably laid down during the waning stages of andesite extrusion and just prior to significant rhyolite ash-fall tuff deposition during the latter part of the Challis activity. 
Table 11. Modal composition of the tuff of Duffey Creek

Volume percent visually estimated from thin sections

Sample Number
Rock Name
Quartz
Sanidine
Plagioclase
Biotite
Rock fragments
Clay matrix
Hornblende
Magnetite
Pumice lumps
Glass shards
Groundmass

$7.27-8 \mathrm{~A}$

9.14-1

Tuffaceous sands tone

Air-fall tuff

35

10

5

1

15

34

--

$-$

$\overline{--}$

$--$

10

14

5

1

--

trace

trace

20

20

29

SAMPLE LOCATIONS

7. 27-8A. SW $1 / 4 \mathrm{SW} 1 / 4$ sec. 3, T. $11 \mathrm{~N} ., \mathrm{R} .14 \mathrm{E}$.

9.14-1. South flank of McGowan Peak 8,400 feet. 
The water-laid conglomerates are generally yellowish-gray (5 Y 7/2) and contain from 10 to 20 percent cobbles and boulders of andesite clasts derived from the local andesite flows. They are found in a matrix of granule- to pebble-sized clasts of 35 percent quartz latite tuff, 5 percent pumice, 60 percent andesite and rhyolite fragments and from 5 to 10 percent tuffaceous sandstone matrix (Fig. 14). The mud-flow breccias and conglomerates are similar except they contain a 15 to 20 percent tuffaceous sand matrix and some petrifled wood.

Attitudes of silicifled tuffs and the alr-fall tuffs located below the obsidian intrusion are horizontal, whereas those beds above the intrusion dip $30^{\circ}$ to the northeast. Alr-fall tuffs found southeast of peak 9,003 are horfzontal. The differences of attitudes are related to the number and size of the volcanic-related intrusions in the area around peak 9,003 .

A friable, vitric, rhyolite air-fall tuff, 250 feet thick, 1les above the volcaniclastic rocks and is the uppermost member of the unit. This vitric tuff may be correlated with the rhyolite crystal tuff (Trt) on Loon Creek Pass 15 miles to the northeast (Stiles, 1976). However, the tuffs described by Stiles (1976) are crystal rich (up to 50 percent of the rock) rather than vitric, and they are 2,200 feet thick. If the rhyolite tuffs are the same unit, then the Loon Creek Pass area may have been closer to the source vent.

The air-fall tuffs generally are white (N9) and fine-grained. Phenocryst content is generally less than 10 percent; however, phenocrysts may comprise up to 25 percent of the rock. In general, phenocrysts are broken due to the explosive character of the Challis eruptions. Sanidine and quartz are the most abundant minerals present and are subhedral to 
anhedral and less than $1.0 \mathrm{~mm}$ in size. Pumice fragments, when present, are from 1.0 to $2.0 \mathrm{~mm}$ in size and show light to moderate compaction. Pumice lapilli, less than $0.5 \mathrm{~mm}$ in size, are structureless grains of glass that are devitrified to clay. Glass shards constitute the majority of the rock and are bubble-wall fragments with trlangular, Y-shaped, straight, slightly curved, or irregular shapes. The shards are from 0.2 to $0.5 \mathrm{~mm}$ long. A modal composition of this air-fall tuff is given in table 11.

The major oxide analyses of the unit is given in Appendix table 1 and the trace element analysis in Appendix table 2. Basalt

Basalt lavas are exposed approximately 1,000 feet north of the confluence of West Fork of Yankee Fork and Lightning Creek, and continue farther for about 3,000 feet towards the west ( $p 1,1)$. These flows are conformably overlain by the tuff of Duffey Creek, but the lower contact is concealed by the terrace gravels and by alluvium. This small flow unit is composed of six individual flows. Each individual flow varies in thickness from 20 to 25 feet and the thickness of the unit as a whole is approximately 150 feet. The outcrops of the five lower flows form prominent small low ridges and the uppermost flow crops out as a 15-foot cliff stained with limonite and hematite.

The flows strike north and have an average dip of $10^{\circ}$ to the west. Some flow layering with the same attitude is visible in the outcrops. It is not known if this attitude is original or if there has been doming by the large rhyolite intrusion to the east. Northeast-trending joints are visible in the outcrops. These basalt flows are strongly magnetic and 
have a normal magnetic polarity.

The weathered surfaces of these lava flows are brownish black ( 5 YR $2 / 1$ ). The fresh rock is greenish black (5 G 2/1) to black (N1), and is fine- to medium-grained. The rock is composed of olivine and plagioclase feldspar phenocrysts that average $1 \mathrm{~mm}$ in size. The phenocrysts amount to about 40 percent of the rock.

One thin section was made from a sample collected from the third flow from the bottom of the unit. The rock is hypocrystalline and porphyritic, and has a subophitic texture. The mode of the rock is 5 percent olivine, 15 percent augite, 35 percent labradorite (An 55), 4 percent magnetite, less than 1 percent pigeonite, less than 1 percent each of hematite and ilmenite and 40 percent glass. The accessories are chlorite, serpentine and sericite. The glassy groundmass is a mixture of glass, palagonite, and microlites of olivine and plagioclase feldspar. Plagioclase feldspar is of labradorite composition and occurs as twinned phenocrysts. The normally zoned plagioclase feldspar phenocrysts have labradorite cores and andesine margins, and are partly replaced by sericite. Augite occurs as euhedral to subhedral colorless phenocrysts, and has a high extinction angle of $40^{\circ}$ to $48^{\circ}$ and a $2 \mathrm{~V}$ of $40^{\circ}$ to $50^{\circ}$. Augite is partly replaced by chlorite and magnetite. Pale-green to pale-brownishgreen, pleochroic pigeonite has a low $2 \mathrm{~V}$ of $20^{\circ}$. Olivine occurs as euhedral to anhedral phenocrysts and has a very high $2 \mathrm{~V}$ of $80^{\circ}$ to $90^{\circ}$. Serpentine partly replaces olivine along fractures.

The basalt lavas are overlain and concealed by the tuffs to the north and intruded (?) by the rhyolite stock to the east; consequently, their source is unknown although basalt dikes are present to the northwest and northeast, and one of these could be the feeder vent. 


\section{Intrusions of Challis Age}

Andesite

Andesite dikes intrude the quartz monzonite and all bedded Challis units in the study area. About one dike per square mile is observed on the average with the frequency increasing slightly near Bonanza Peak. The dikes range in width from a few inches to 40 feet and in length from 100 to 1,000 feet. The larger dikes form distinctive outcrops, 10 to $20 \mathrm{feet}$ high, with small aprons of talus at their bases. Joints that strike N. $61^{\circ}$ W. and N. $31^{\circ}$ E., and dip $89^{\circ}$ N. and $82^{\circ}$ N. respectively were open during the Challis volcanic event and occupled by the andesite dikes.

The andesite dikes have three well-developed blocky joint sets that have from 1- to 4-foot spacings. One set appears to be parallel to the trend of the dikes, and the other two sets at right angles to the first.

The dikes are dark gray (N3) to greenish gray (5 GY 6/1) when unweathered and pale yellowish brown (10 YR 6/2) when weathered. They are porphyritic and contain phenocrysts of plagioclase and biotite. The phenocrysts are 1 ight gray (N8) and make up 10 percent of the rock.

Most of the dikes are andesitic in mineralogical composition although some are rhyodacitic in chemical composition as indicated by major oxide analysis in Appendix table 1. Some were probably feeder dikes for the andesites of Bonanza Peak, which are, themselves, intruded by andesite dikes.

The more silica-enriched rhyodacite dikes, in general, are found intruding the andesite flows while those less enriched in silica are found in the quartz monzonite. The andesite dikes probably were intruded over a broad area during the initial volcanic activity, and their emplacement con- 
Table 12. Modal composition of the andesite dikes

Volume percent visually estimated from thin sections

$\begin{array}{lccc}\text { Sample Number } & 72314 & 9132 & 705 * \\ \text { Rock Name } & \begin{array}{c}\text { Augite } \\ \text { Hornblende } \\ \text { Andesite }\end{array} & \begin{array}{c}\text { Biotite } \\ \text { Hornblende } \\ \text { Andesite }\end{array} & \begin{array}{c}\text { Augite } \\ \text { Andesite }\end{array} \\ \text { Plagioclase } & 15 & 20 & 30 \\ \text { Augite } & 1 & -- & 5 \\ \text { Biotite } & -- & 1 & - \\ \text { Hornblende } & 6 & 2 & -- \\ \text { Opaques } & 10 & 2 & 1 \\ \text { Groundmass } & 68 & 65 & 60\end{array}$

\section{SAMPLE LOCATIONS}

72314. 2-1/2 miles up Lower Hardin Creek, on middle slope of ridge 8411 . 9132. Head of Crealey Creek, intrudes Wood River Formation.

705. On H1ghway US $931 / 4$ mile west of American Creek. 
tinued at intervals during the later stages of volcanic activity.

The less silica-enriched dikes are more irregular in shape and appear to have been less viscous than the rhyolite dikes. An augite andesite $d^{*} k e$ at the mouth of American Creek, previously called a lamprophyre by Choate (1962, p. 16), has thin apophyses in the surrounding quartz monzonite. The andesite dike at the head of American Creek has small $5 \mathrm{~mm}$ diameter calcite-filled vesicles that dip $35^{\circ}$ to the southeast that might Indicate tilting due to normal movement on the Sawmill Creek fault.

Three thin sections of the unit were prepared and their modal compositions were visually estimated (Table 2). The rocks are hypocrystalline to holocrystalline with medium- to fine-grained phenocrysts of glomerophyric augite and of plagioclase. The plagloclase is albite twinned and normally zoned and contains inclusions of zircon and apatite. The minerals are similar in appearance to those previously discussed in the andesite of Bonanza Peak, with the exception that the biotite and hornblende are greentsh-brown. The groundmass is generally composed of felsophyric devitrifled glass, although the augite andesite at the mouth of American Creek has a groundmass of glass. The plagioclase and groundmass is commonly altered to calcite and kaolinite, possibly because of deuteric processes.

The trace element concentrations (in Appendix table 2) are similar to those concentrations observed in the andesite of Bonanza Peak. Rhyolite of West Fork

The rhyolite of West Fork is a series of dikes and associated lava flows within the Challis Volcanics and a dike swarm within the Idaho batholith. The rocks may be elther aphanitic, porphyritic, or vitro- 
phyric and some intrusions have a gradation from aphanitic to porphyritic. It is not known, for certain, if all rock bodies named as rhyolite of West Fork on Plate 1 are of the same age. Also, the age relations between the rhyolites of West Fork and McGowen Peak are in doubt, but we believe on the basis of simflar chemical composition (Appendix table 1) and location of emplacement that they are equivalent in age. Distinctive, hematite-stained, resistant peaks, ridges and cliffs, aproned with abundant talus, are characteristic of the larger intrusions. Vertical and (or) horizontal columnar joints are present in some of the outcrops. The unweathered rock varies from a very pale purple (5 P 7/2) to pale yellowish brown (10 YR 7/2) to dark pinkish gray (5 YR 7/1). Flow layering with irregular attitudes is present in most of the outcrops. Many of the rhyolite ridges and peaks are covered with felsenmeer of loose rock fragments. The contacts between the intrusions and the country rock are sharply defined and, in places, are autobrecclated. Chilled margins that occur along the edges of some of the intrusions are glassy.

Small aphanitic dikes and domes occur either in association with the porphyritic intrusions, or as individual intrusions throughout the northern part of the area. These aphanitic intrusions weather in outcrop to a dark reddish brown (10 R $3 / 4)$ to moderate yellowish brown (10 YR 5/4). These intrusions are not columnar jointed or brecclated, but they are hematite-stained. At peak 9,003 an extrusive aphanitic dome has given rise to a flow of aphanitic rhyolite.

Radial dikes are associated with some of the rhyolite intrusions, and these dikes in hand specimen have the same color and texture as the 
aphanitic lava domes. It is belleved that these radial dikes are due to sma11 volcanic centers.

A11 of the dikes are from 3 to 10 feet thick and from 20 to 3,000 feet long. These dikes intrude most of the layered volcanic units in the area. North of Sunday Creek, a rhyolite dike swarm trends northeast, and Intrudes both the Idaho batholith and the Challis volcanic rocks. A few of these dikes contain phenocrysts of quartz and sanidine but most are aphanitic.

A hypabyssal, granophyric rhyolite dome with related lava flows occurs northwest of Cabin Creek Peak. The rhyolite is aphanitic, and an unweathered surface is light grey (N7). The rock weathers to a moderate orange (5 YR 7/6). The dome is assumed to be similar in age and chemical composition to the rhyolite of West Fork. The rock contains 90 percent undifferentiated quartz and alkalic feldspar and 10 percent perthite, all occuring as granophyric intergrowths. A single dark-yellowishorange (10 YR 6/6) veinlet, 1/8-inch wide, cuts the rock and contains limonite, pyrite, and secondary quartz.

Obsidian domes and sills, or possibly thin lava flows, occur in the area surrounding peak 9,003. The obsidian is black (N1) to moderate olive brown (5 Y 4/4), has perlitic fractures, contains less than 1 percent quartz phenocrysts, and has scattered chalcedony-filled vugs and fractures. The obsidian bodies contain 20 percent sanidine and quartz phenocrysts, from 2 to $5 \mathrm{~mm}$ in size. No mafic mineral occurs as phenocrysts that can be recognized under the hand lens.

Petrographic studies of 19 hand specimens (see table 13) indicate 
that most of the rhyolite is composed of micro- and crypto-felsitic groundmass which has resulted from the devitrification of an original glassy matrix. The remainder of the rock is composed of phenocrysts of sanidine, plagioclase and quartz. The flow-layers are segregations of quartz and alkalic feldspars and the groundmass. Quartz phenocrysts are commonly embayed and partly resorbed.

There is no alteration of these bodies other than weathering except In the area around Hindman Ridge and Red Mountain. Sanidine occurs as subhedral crystals from 0.3 to $2.0 \mathrm{~mm}$ in size. These crystals commonly show partial alteration to sericite, particularly along cleavage planes. Biotite and hornblende are present in about half of the thin sectlons studied. These minerals are subhedral and less than $0.5 \mathrm{~mm}$ in size. They comprise about 1 percent of the rock and commonly show partial alteratton to chlorfte. Accessory minerals include zircon, apatite, and magnetite.

Petrographically, the aphanitic rhyolite is composed of micro-porphyritic and, at some localities, porphyritic (less than $1.5 \mathrm{~mm}$ in size), normally zoned and polysynthetically twinned plagloclase feldspar (An 10 to $A n_{24}$ ), with thin veinlets of primary quartz. Where the quartz appears as phenocrysts it is subhedral, embayed, less than $1 \mathrm{~mm}$ in size, and is simflar in appearance to quartz phenocrysts seen in the porphyritic rhyolites. Greater than 90 percent of the rock is composed of a micro- and crypto-felsitic groundmass which has resulted from the devitrification of an original glassy matrix, similar to that of the porphyritic rhyolites. One rhyolite lava flow, seemingly not associated with any rhyolite 
Table 13. Modal composition of the rhyolite of West Fork

Volume percent visually estimated from thin sections

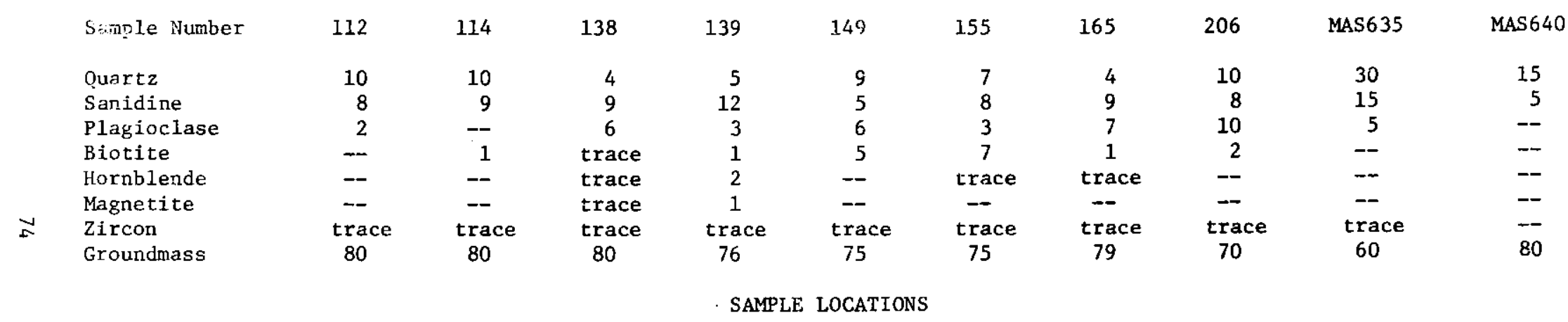

112. 0.3 mile north of peak 7,434 feet in the northern-most part of the area.

114. On peak 7,434 feet in the northern most part of the area.

138. Peak 8,962 feet in the southwest part of the area.

139. 1,000 feet north of peak 8,962 feet in the southwest part of the area.

149. 1,500 feet north of peak 8,865 feet in the southwest part of the area.

155. 1,000 feet north of peak 8,682 feet in the southwest part of the area.

165. Peak 7,721 feet in the west-central part of the area.

206. Peak 9,002 feet in the southwest part of the area.

MAS635. See plate 4.

MAS640. See plate 4 
Table 13. continued; Modal composition of the rhyolite of West Fork

Volume percent visually estimated from thin sections

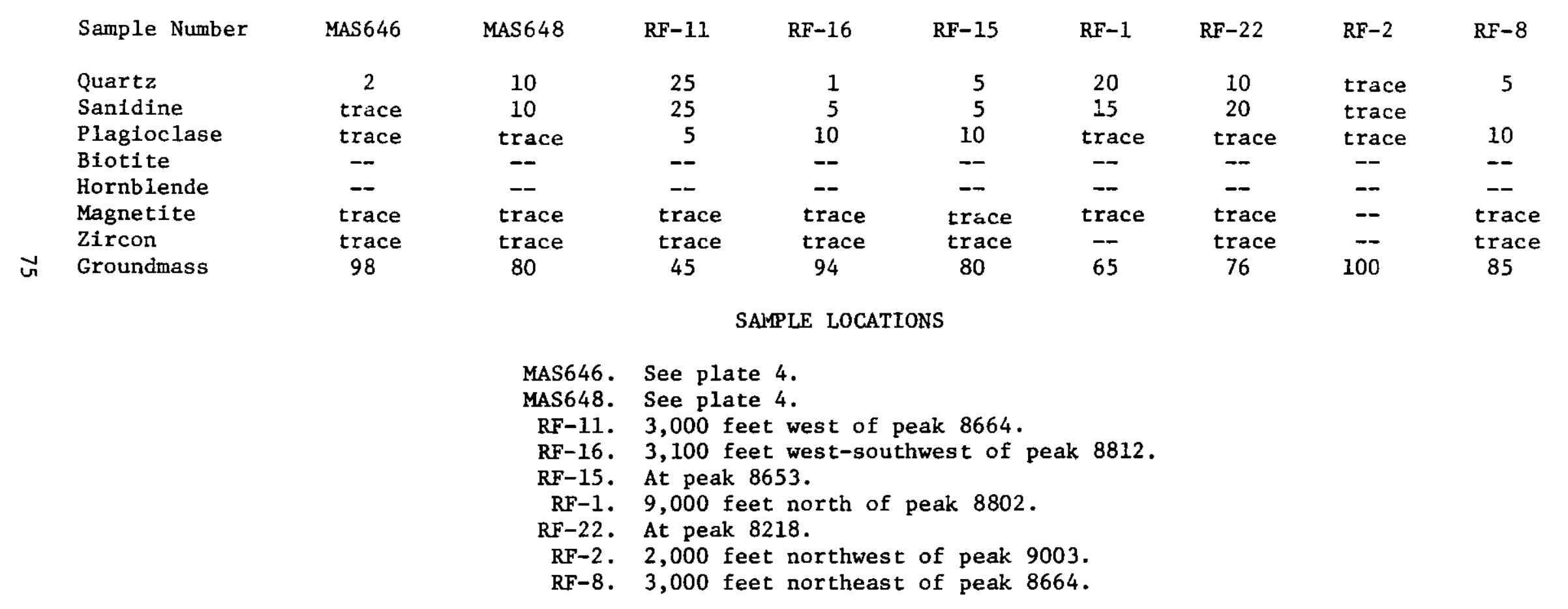


intrusion, occurs 500 feet northeast of Hill 8601 (p1. 1). The lava flow is 150 feet wide, is of unknown thickness and length, and extends north-northeast. Though the source of the lava flow is unknown, the color and composition of the rock is the same as the rhyolite of West Fork. In outcrop, the lava flow is distinctive because it was extruded over the tuff of Duffey Creek. The rhyolite flow is blocky, resistant to weathering, auto-brecclated, and moderately iron-stained. Twenty percent of the rock in hand specimen is composed of quartz and sanidine phenocrysts, from 2 to $5 \mathrm{~mm}$ in size. There has been some devitrification of the glassy groundmass.

The trace element analyses for the rhyolite of the West Fork are presented in Appendix table 2.

\section{Rhyolite of McGowan Peak}

The rhyolite of McGowan Peak occurs as a large extrusive dome and associated lava flows on McGowan Peak, as a stock 1,000 feet east of the confluence of West Fork, Yankee Fork, and Lightning Creeks, as a dike swarm to the west of McGowan Peak, and as individual dikes within the Idaho batholith. Although hand specimens appear to be quartz latite in composition, chemical analyses show that this unit is a rhyolite and similar to the rhyolite of West Fork.

A swarm of radial dikes extends from McGowan Peak to the west. Some of these dikes are en echelon and may be longer than 1 mile. Individual dikes are, in general, about 400 feet in length and range from 3 to 30 feet in width. One dike west of McGowan Peak (3,000 feet northwest of the confluence of Duffey and Basin Creeks) is the only Challis-age dike that crosscuts the contact between the quartz monzonite of the Idaho batholith and the Challis Volcanics. 
Black resistant peaks and ridges, aproned with abundant 1ightcolored talus, are characteristic of the rhyolite of McGowan Peak. The color of the unweathered rock is yellowish gray (5 Y 7/2) to grayish brown (5 YR 2/3).

Phenocrysts of quartz, plagioclase feldspar, and sanidine in variable amounts and up to $4 \mathrm{~mm}$ in size, constitute 25 percent of the rock. Phenocrysts of biotite constitute less than 5 percent of the rock and are as much as $2 \mathrm{~mm}$ in length. The lack of red coloration of the weathered rock and the composition of the phenocrysts distinguish the rhyolite of McGowan Peak from the rhyolite of West Fork. A cut surface of unweathered rock, leached with hydrofluoric acid and stained with a solution of sodium cobaltinitrate, indicates that the potassium feldspars predominate over the plagioclase feldspars and quartz within the groundmass.

In thin sections, the unit is composed of quartz, sanidine, plagioclase, and hematite, with trace amounts of magnetite, biotite, and hornblende (see table 14). The quartz, from 0.4 to $3.5 \mathrm{~mm}$ in diameter, 1s subhedral to euhedral in shape. In some cases, the phenocrysts have been fractured and are partly resorbed into the groundmass.

Sanidine, euhedral to subhedral in shape, is Carlsbad twinned. Phenocrysts are from 0.3 to $3 \mathrm{~mm}$ wide and from 1.0 to 5.0 in length. The sanidine on McGowan Peak is unaltered, but within the dikes, it is partly altered to kaolinite.

Plagioclase $\left(\mathrm{An}_{15}\right.$ to $\mathrm{An}_{38}$ ) is euhedral to subhedral, normally zoned, and is from 0.3 to $1.3 \mathrm{~mm}$ wide and from 0.5 to $5.0 \mathrm{~mm}$ long. The plagioclase is albite twinned, although Carlsbad twins may be present. Phenocrysts are partly altered to kaolinite and calcite. 
Table 14. Modal composition of the rhyolite of McGowan Peak

Volume percent visually estimated from thin sections

$\begin{array}{lccrr}\text { Sample Number } & 6.24-3 & 7.13-5 & 9.06-5 \mathrm{~B} & 9.10-1 \\ \text { Quartz } & 10 & 10 & 10 & 15 \\ \text { Sanidine } & 8 & 15 & 8 & 12 \\ \text { Plagloclase } & 12 & 4 & 3 & 8 \\ \text { Biotite } & \text { trace } & 1 & -- & 1 \\ \text { Hornblende } & -- & -- & 1 & -- \\ \text { Magnetite } & \text { trace } & \text { trace } & 1 & -- \\ \text { Hematite } & \text { trace } & -- & 2 & -- \\ \text { Groundmass } & 70 & 70 & 75 & 64\end{array}$

SAMPLE LOCATIONS

6.24-3. SE1/4SW1/4 sec. 21, T. $11 \mathrm{~N}$, , R. $14 \mathrm{E}$.

7.13-5. One-third mile $\mathrm{NE}$ of the NW corner sec. 6, T. 11 N., R. 14 E.

9.06-5B. SE flank of McGowan Peak, at 8,600 feet elevation.

9.10-1. NE1/4NW1/4 sec. 1, T. 11 N., R. 13 E. 
Biotite occurs as subhedral platy grains from 0.2 to $1.1 \mathrm{~mm}$ in length. It is pleochroic in green and brown, but in some cases, it is bleached and partly altered to chlorite. The hornblende, subhedral in shape, occurs as light- to dark-green pleochrolc phenocrysts, $0.5 \mathrm{~mm}$ in dlameter. Magnetite, silver-black in reflected light, is from 0.01 to $0.3 \mathrm{~mm}$ in size and is subhedral to eudral. The magnetite is partly altered to hematite. The groundmass is a mixture of crystallites and microlites of feldspar, quartz, and biotite.

Appendix table 1 gives the mafor oxide analyses of the rhyolite of McGowan Peak. Trace element analyses are given in Appendix table 2. Basalt

Thin basalt dikes occur on the east and northeast flanks of Red Mountain, 400 feet south of peak 8,449 west of Basin Creek, and 800 feet west of peak 8,317. A larger body, partly extrusive and partly intrusive occurs north of Cabin Creek (see p1. 1). The basalt dikes on Red Mountain are from 5 to 40 feet wide and up to 2,000 feet in length. The dike south of peak 8,449 is 2 feet wide and 30 feet in length and is part of a composite andesite dike. The basalt dikes are distinctive and easily recognized by their color.

The basalts are brownish black ( 5 YR 2/1) to dark gray (N3), with limonite or hematite staining. Hand samples contain phenocrysts of plagioclase feldspar (40 percent) set in a glassy groundmass (60 percent). Bhatt (1978) has described a propylitically altered sample, taken 3,000 feet northeast of Red Mountain, that in a single thin section contains 30 percent plagioclase feldspar $\left(\mathrm{An}_{42}\right.$ to $\left.\mathrm{An}_{55}\right), 40$ percent glass, 12 percent augite, 2 percent pigeonite, 3 percent magnetite, 1 percent hematite, 
2 percent sericite, and less than 1 percent olivine, calcite, serpentine, epidote, and iddingsite. The texture of this basalt dike is subophitic. 
Surficial deposits of Quaternary age consist of glacial deposits, terrace gravels, landslide deposits, talus, and alluvium.

Glaclal Deposits

Glacial deposits are located along the headwaters of West Fork, Yankee Fork, Cabin Creek, and Basin Creek as well as along the streams and valley sides east and west of Cabin Creek Peak, and along the hanging valleys carved by the glaclers that emanated from Red Mountain. These deposits, which are largely glaciofluvial in origin, consist of unconsolidated sand, gravel, and boulders of various lithologies found in the source areas.

Other glacial deposits are found at the head of Polecamp Creek and a small tributary about $1 \mathrm{mile}$ south of East Basin Lake. These are ground moraine and consist mainly of unconsolidated gravel and boulders derived from the adjoining Idaho batholith highlands. The deposits are found where the streams are north-flowing and their headwaters are above 8,000 feet. The deposits extend down to 7,000 feet on the valley floor and are only a few feet thick except near the glaclal source, where the deposits may possibly be from 50 to 100 feet thick. Ross (1937, p. 76) and Williams (1961) belleve that the moraine deposits in the Stanley area of Idaho were deposited during the Wisconsin age.

\section{Terrace Gravels}

Terrace gravels are found along most of the major drainages in the area, particularly along parts of Basin Creek, along the West Fork drainage, along the Yankee Fork north of Polecamp Creek to Jordan Creek, at 
the mouth of the Yankee Fork, and along the Salmon River. The gravels have been divided into two groups based on their elevation above the present stream bed. The top surface of the lower stream terraces is between 10 and 30 feet and the top of the upper terrace is between 70 and 120 feet above the present level of the stream. The stream terraces are composed of about 50 percent rounded boulders and pebbles of varying lithologies, and about 50 percent of sand and clay in varying proportions. The two terrace gravels found along the Yankee Fork are composed of clasts estimated to be 30 percent andesite, 30 percent andesite breccia, 10 percent banded rhyolite, 20 percent phyllitic quartzite, and 10 percent quartz monzonite. These clasts are loosely held in a tuffaceous sand that comprises 30 percent of the deposits. These gravels have been worked for gold. An upper terrace is elevated 120 feet above the Yankee Fork near Ramey Creek and 70 feet near the Bonanza Guard Station. The lower terrace is elevated 10 to 30 feet above the Yankee Fork by the mouth of the West Fork.

The terraces on the Salmon River and at the mouth of the Yankee Fork are similar to those described above except that the quartz monzonite makes up 70 percent of the clasts. The remainder is andesite. The terraces were formed when the area experienced geologically recent uplift and rejuvenation of the Salmon River (Choate, 1962, p. 3). The Salmon River has since downcut 150 feet below the level of the terraces. The debris is believed to have been carried to its present location by glacial melt waters from Pleistocene glaciers (Anderson, p. 11). The upper terrace was possibly formed when glacial debris was downcut by the Yankee Fork as it cut the canyon below Polecamp Creek. The lower terrace Is the remnant of a broad valley that formed after the glacial activity. 
Landslide Deposits

Sma11 areas of landslide deposits are found at many localities throughout the area. Some of the larger are at 50 feet south of the confluence of West Fork and Cabin Creek, approximately 4,000 feet northeast of Red Mountain Peak, about a mile and a half northeast of Cabin Creek, near the head of Coal Creek, along Basin Creek about halfway between Duffey Creek and Little Basin Creek, along Adair Creek and East Basin Creek, associated with the rhyolite intrusions at peak 9,003 (p1. 1), and south of peak 8,248 . The landslides are probably the result of incompetent tuff beds, faulting and fracturing, and by the hydrothermal alteration to argillic zones around Red Mountain. The deposits consist of cobbles and boulders of various lithologies derived from the local area.

Talus

Talus deposits found at the base of cliffs and as coverings on some slopes in the area consist of unconsolidated angular cobbles and boulders. Talus debris is derived from the underlying country rock. Alluvium

Alluvium is found in the lower portions of all the stream valleys In the area. The alluvium contains up to 80 percent boulders and pebbles; the remainder of the alluvium is made up of sand and finer grained material. The exact percentages of pebbles, sand, and clay in the alluvium at a particular locality depends to a large degree on the velocity of the creek at that locality. Boulders and pebbles are generally rounded, though the material may be more angular where it is exceptionally close to its source. The lithology of the pebbles is variable, but most of the resistant rock 
types of the area are represented at a given locality. The alluvium on the Yankee Fork above Polecamp Creek, on American Creek $1 / 2$ mile north of the Salmon River, at the mouth of Adair Creek and on the lower half of Rankin Creek have been dredged or sluiced for gold. Alluvial fans are located along Cabin Creek (pl. 1). The streams which are flowing into Cabin Creek have deposited sand- to clay-sized washed materials at their mouths. These generally form a triangular shape in plan view. 


\section{STRUCTURE}

Some major structural features in the Yankee Fork area and adjacent areas are readily apparent from the present study (pl. 1) and from past studies by Broili (1974), Cass (1973), and Crist (1978). The faults exercise the dominant control of the distribution and outcrop patterns for a11 the geological units, as well as control the positions of intrusions and volcanic vents of Challis age. Also, the Challis volcanic beds have a regional tilt of approximately $20^{\circ}$ to $25^{\circ}$ towards the southeast. In detail, the structural features are complex and obscure because of the large range in age, from Permian to Eocene, of the geological units; because of the lack of thin and continuous marker horizons within the Challis Volcanics; and because of the presence of intrusions of batho1ith size. 


\section{General Setting}

The Challis Volcanics and urantferous arkosic beds are confined to an 8-mile belt, or graben, that trends N. $45^{\circ}$ E. (p1. 1). The belt is surrounded on all sides except the northeast by the pre-Challis units of quartz monzonite of the Idaho batholith and Wood River Formation. The southwestern end of the belt of volcanic rocks is present within the study area at Stanley Basin and along the Basin Creek valley, but, to the northeast, the belt widens and opens to form the main outcrop area of the Challis volcanic field.

The northwestern and southeastern margins of the belt are segmented and are formed by a number of straight linear and arcuate faults with a variety of trends, dominantly northeast ( 1.1$)$. These marginal faults drop down the Challis Volcanics so that the latter forms the interior of a broad, but shallow, graben in the center and northeast of the study area ( $p 1.2$, sections $A-A^{1}$ and $B-B^{1}$ ). The base of the Challis within the graben seems to plunge at a low angle towards the northeast, perhaps caused by a trap-door tilting of the subsided block, and the volcanic sequence thickens in the same direction. The long axis of the graben is approximately parallel to the trend of the porphyry dike swarm of Challis age which extends from Boise Basin, outside the study area; borders the northwestern edge of the study area near Hindman Lake and Cabin Creek Peak; and continues into central Montana, (Hyndman and others, 1977: Siems and Jones, 1977). The long axis of the Casto pluton, an epizonal batholith of Challis age 40 miles to the north of Stanley Basin, also is approximately parallel to the trend of the graben. 
The amount of subsidence of the volcanic block within the graben is difficult to estimate because of the lack of marker horizons outside the graben walls and because of the undulating, possibly rugged, topographic surface over which the Challis Volcanics were deposited. However, a consideration of the thickness of Challis Volcanics and the position of the pre-Challis surface leads to estimates of subsidences of about 2,000 feet on the northwestern marginal fault near Red Mountain (see $\mathrm{pl} .1$ and $\mathrm{pl}$. 2, section $D-D^{1}$ ) and of a minimum of 1,000 feet on the Yankee fault-Sawmill Creek fault along the southeast margin (see pl. 1 and $\mathrm{p} 1$. 2 , section $B-B^{1}$ ). The large uncertainty about the amount of subsidence does not allow estimates of the depth of the uraniferous lower unit of the arkoses and tuffaceous sandstones of Coal Creek, if it is present, beneath the volcanic floor within most of the graben. Only near the outcrops of the lower unit in Stanley Basin can such estimates be reasonable; increasing uncertainty accompanies increasing distance from the outcrops towards the northeast. Along the line of the West Fork of Yankee Fork, the pre-Challis basement might be at any depth between 100 feet and 1,000 feet. 
Faults

Most of the faults shown in plates 1 and 2 were traced in the field but some, those that are concealed by alluvium or talus, were traced as linears on aerial photographs. Almost all the faults have dips that are vertical or within $15^{\circ}$ of verticality. Displacement on faults, where observed, is dip-slip. Strike-slip displacement seems to be uncommon but this could be due to an inablility in the fieldwork to recognize horizontal off-set because of the lack of thin marker beds in the Challis Volcanics.

The rock units in the study area are disrupted by many faults which have large and small displacements. The faults have many different attitudes; Anderson (1949, p. 13) distinguished five and Choate (1962, p. 26) distinguished seven. We conclude that six fault sets are present In the area. In approximate relative order of importance the fault trends are:

1) N. $65^{\circ}$ E. faults,

2) N. $25^{\circ}$ E. to N. $45^{\circ}$ E. faults,

3) N. $45^{\circ}$ W. faults,

4) N. $10^{\circ}$ W. to $N \cdot 10^{\circ}$ E. faults,

5) N. $80^{\circ}$ E. to N. $100^{\circ}$ E. faults, and

6) N. $70^{\circ}$ W. faults.

The fault sets will be discussed briefly and in order.

Faults with a $N .65^{\circ}$ E. trend are relatively few in the study area but this set is important in the district because they are long and persistent. Three of the faults have been named in previous studies from 
outside the area. The Mormon Bend fault (Tschanz and others, 1974) extends from Stanley into the southwestern edge of the map area ( 1 1. 1) a1though its continuation east of Basin Creek is difficult to trace. A dacite dike follows the line of the fault but this dike assumes an east trend, splits into two, and disappears to the east of Upper Hardin Creek. The Sunbeam Hot Springs on the Salmon River are 2 miles to the east on the line of this east-trending possible extension of the Mormon Bend fault. The presence of hot springs characterizes the line of the Mormon Bend fault to the southwest of the study area.

The Doran Gulch fault (Tschanz and others, 1974) is present at the head of Kelley Creek about I mile west of the western boundary of the study area ( 1.1$)$. The fault seems to weaken and die out in the area of Basin Creek but, perhaps coincidentally, it is on line with the Sawmill Creek fault 4 miles to the east although it cannot be traced across the intervening volcanic rocks.

The Yankee Fork fault with a N. $65^{\circ}$ E. trend enters the study area from the northeast ( $\mathrm{p} 1.1$ ). At Bonanza the fault efther bifurcates into or is joined by the Sawmill Creek fault, which has a N. $45^{\circ}$ E. trend. The Yankee Fork fault can be traced 6 miles to the southwest of Bonanza before it disappears in the vicinity of the McGowen Peak volcanic dome. The intrusion of the dome was probably controlled by the presence of the fault. The Yankee Fork fault is believed to have strike-slip displacement to the northeast of Custer (D.H. McIntyre, oral communication 1977), but in the study area the apparent displacement is dip-slip, down to the northeast.

The N. $25^{\circ}$ E. to N. $45^{\circ}$ E. faults are numerous and important in the study area because they form the major controls of the northwest and south- 
east margins of the volcanics-filled graben. The Sawmill Creek fault (p1. 1 and p1. 2, section $C-c^{1}$ ), although somewhat arcuate, has this general trend as does the boundary fault to the southwest and north of Red Mountain ( 1.1 and p1. 2, section $D-D^{1}$ ). Both of these faults have probable dip-slip displacements that exceed 1,500 feet. Other faults with this trend include those north and south of the West Fork, also at Short Creek and Duffey Creek.

Faults with the $N .45^{\circ}$ W. trend are short, open tensional faults of the kind that form low quartz monzonite ledges observed around the Alta claims on the west fork of Upper Harden Creek (p1. 1). Uranium-bearing hydrothermal solutions filled this fault trend which might indicate that the faults had some pre-Challis movement. The Wood River Formation south of Bonanza Peak (p1. 1) has been uplifted at least 3,000 feet with respect to the Challis Volcanics by other faults with this trend. This displacement must be post Challis.

Other faults in this category occur along parts of Basin Creek where the motion appears to be primarily strike-slip and a parallel set of faults to the north of Basin Creek along which the motion appears to be primarily dip-slip. These dip-slip faults separate the Idaho batholith rocks from the rocks of the Challis Volcanics. The motion along the strike-slip fault in Basin Creek is indicated by displacement of a dike located near the mouth of the creek. This dike is offset about 250 feet, with the displacement giving a sense of right lateral movement. offset along the dip-slip faults is variable. A displacement of over 1,000 feet has occurred on a part of the fault between Coal Creek and East Basin Creek in sec. 17, T. 11 N., R. 14 E.; this is indicated by the thickness 
of the andesite of Bonanza Peak that is down-dropped relative to the adjacent porphyritic quartz monzonite. Displacement along faults with similar trends may be on the order of only 200 or 300 feet as seen in the Red Mountain area. In other areas the displacement is only 5 to 50 feet. The N. $45^{\circ}$ W. and N. $45^{\circ}$ E. fault trends are probably related to the graben-like structure found in this study. The formation of this structure probably occurred following the eruption of the tuffs of Duffey Creek and during the last stages of volcantsm in which the underlying magma chamber had been largely emptied. The prominent line, from McGowan Peak to Hindman Lake, of volcanic domes and vents now filled by the rhyolltes of West Fork and McGowan Peak, has a N. $45^{\circ}$ W. trend (p1. 1). The vents were probably controlled by a fault that belongs to the $\mathrm{N} .45^{\circ} \mathrm{W}$. set.

A number of river and stream valleys, dikes and lines of rhyolite domes are aligned approximately north-south. Some observed small faults also have this trend which varies from about N. $10^{\circ} \mathrm{W}$. to N. $10^{\circ} \mathrm{E}$. Portions of the Yankee Fork, Basin Creek, Lower and Upper Hardin Creeks are evidently controlled either by faults or by prominent joint sets with this trend. The alignment of dikes and domes of rhyolite of West Fork to the east of Lightning Creek and a second line to the east of Cabin Creek follow the same trend (p1. 1). Faults with a north trend are found in the Stanley Basin area where they border outliers of volcanic rocks in the quartz monzonite and where they form, in part, the graben walls. The boundary arcuate fault to the east of Coal Creek has a small displacement in the south that increases to at least 1,000 feet in the north.

Many short faults in the study area have a trend that is approximately east-west, from N. $80^{\circ}$ E. to N. $100^{\circ}$ E. Some segments of the 
graben walls near Basin Creek and Red Mountain have this trend. The fault that downthrows the andesite of Bonanza Peak against the Wood River Formation on the south flank of Bonanza Peak has the largest displacement, approximately 2,000 feet, of these faults.

The faults with a $N \cdot 70^{\circ} \mathrm{W}$. trend are relatively few in number and might be members of the preceeding set of faults. They occur as shear zones in the quartz monzonite to the west of Yankee Fork, and as an arcuate fault bounding the volcanic rocks between the east Basin and coal Creeks. Andesite and dacite dikes east of Yankee Fork and east of Basin Creek a1so have this trend. 
The Wood River Formation adjacent to the quartz monzonfte contact on the Yankee Fork contains minor folds that probably formed at the time of intrusion. Poor exposure and limited study of the Wood R1ver precludes any spectfic analysis of these folds. However, the bedding, which has an attitude of N. $05^{\circ}$ E., $20^{\circ}$ E. 1 mile east of the contact on Ramey Creek, changes to N. $10^{\circ}$ W., $75^{\circ}$ E. near the contact and in some areas the beds appear overturned. The north-trending contact in this area has possibly caused local shortening to the east to form folds having northtrending axes.

Anderson (1949) described major folds, with axes trending northeast, within the volcanic terrain found in the study area. None of these folds were observed during the present study.

The volcanic beds have a regional dip to the southeast in the areas of Bonanza Peak, Jordan Creek and Lightning Creek, and to the south in the area between the West Fork, Sawnill Creek and East Basin Lake (p1. 1). In Stanley Basin and the Basin Creek drainage the attitudes are more erratic and a northeast dip is common. Variations in attitude within the volcanic beds probably are the result of faulting and the rotation of fault blocks rather than from folding.

Sma11-scale drag folds are recognized within the tuff of Duffey Creek northwest of McGowan Peak, and occur where the rhyolite intrusive rocks have deformed the overlying country rock.

The regional dip from $20^{\circ}$ to $35^{\circ}$ must be due to regional tilting of the Challis Volcanics after deposition of the tuff of Duffey Creek be- 
cause ash-flow tuffs, which are deposited only at low initial dips, are part of the volcanic sequence. The tilting might be the result of either doming of the volcanic cover by the Challis-related, epizonal Sawtooth and Casto granite batholiths or isostatic rebound of this region of central Idaho that followed the close in Eocene time of the crustal emplacement of batholiths that had started in the late Cretaceous. A more remote possibility might be that the dip is a result of basin-and-range faulting which disrupted the southern half of the Challis volcanic field in Miocene time (Siems and Jones, 1977). 
Joints are best developed in the quartz monzonite phases of the Idaho batholith and the majority of field measurements were made on joints in those phases that were observed on ridge tops, canyon walls, and roadcuts. The joints in the andeste flows of the Challis Volcanics are grouped as members of three sub-perpendicular joint sets. A platy joint set spaced at 3- to 12-inch intervals is sub-parallel to the flow contacts. The other two joint sets are blocky and spaced at 1- to 30-foot intervals. The andesite and rhyolite dikes of the Challis Volcanics have three blocky joint sets, spaced at 3- to 15-foot intervals perpendicular to each other, with one set parallel to the dike walls. Most of the Challis dikes exhibit sub-horizontal columnar foints. These columnar joints are characterized by columns that range from 6 inches to 8 feet in length. The hexagonal outline is less common than the pentagonal. Rhyolitic intrusions commonly show vertical and horizontal columnar jointing. These columns range from 4 to 8 inches in diameter and from 2 to 6 feet in length.

The most prominent joint trend in the volcanic rocks is to the northeast. In addition to this northeast trend, a northwest trend is also found. The joints are well-defined particularly in the flow rocks and the densely welded zones of the ash-flow tuffs. The blocky joint trends in the Challis volcanics were found by Broill (1974, p. 79) to fit the N. $70^{\circ}$ W., N. $45^{\circ}$ W., N. $60^{\circ}$ E., N. $45^{\circ}$ E., N. $10^{\circ}$ W., and N. $65^{\circ}$ E. fault trends described by Choate (1962, p. 22). These foint sets, therefore, are probably controlled by the regional stresses rather than being simple cooling joints. 
The joints in the Idaho batholith are generally blocky and spaced regular1y although they can be lamellar and spaced irregularly. The jolnts can contain aplite, pegmatite, and Challis-related dikes. They generally form three sub-perpendicular joint sets from 3 to 15 feet apart. Two hundred sixty-two normal poles from the joints found in the quartz monzonite were plotted on the lower hemisphere of a Schmidt equal-area net (fig. 1) using a modified U. S. Geological Survey computer program which plots linear data as poles in an equal area net (see figs. 1,2, and 3 ).

One prominent set strikes N. $68^{\circ}$ E. and dips $72^{\circ}$ S. This joint trend exists principally in the porphyritic phase of the quartz monzonite, (fig. 3). The joint trend is primary because joints in this trend are locally filled by pegmatite and aplite dikes. Ten out of 68 pegmatite and aplite dike observations were found to fill foints of this trend. The four other primary joint systems which are locally filled by 58 measured pegmatite and aplite dikes are the N. $88^{\circ}$ E., $41^{\circ}$ N., N. $52^{\circ}$ W., $53^{\circ}$ N., N. $67^{\circ}$ W., $70^{\circ}$ N., and N. $32^{\circ}$ E., $77^{\circ}$ N. joint trends (fig. 1). The joint trends that locally contain pegmatite and aplite dikes must have had an extensional component to allow these dikes to enter these foints. This extensional component probably existed during the late-stage stresses that accompanied the emplacement of the quartz monzonite during the Laramide orogeny.

A N. $88^{\circ}$ E., $41^{\circ}$ N. joint system is the most recent of the joint sets. In several areas in the equigranular quartz monzonite along the Yankee Fork the joints of this trend are filled by veins that contain native gold, pyrite, sphalerite, galena, and quartz (figs. 1 and 2). 


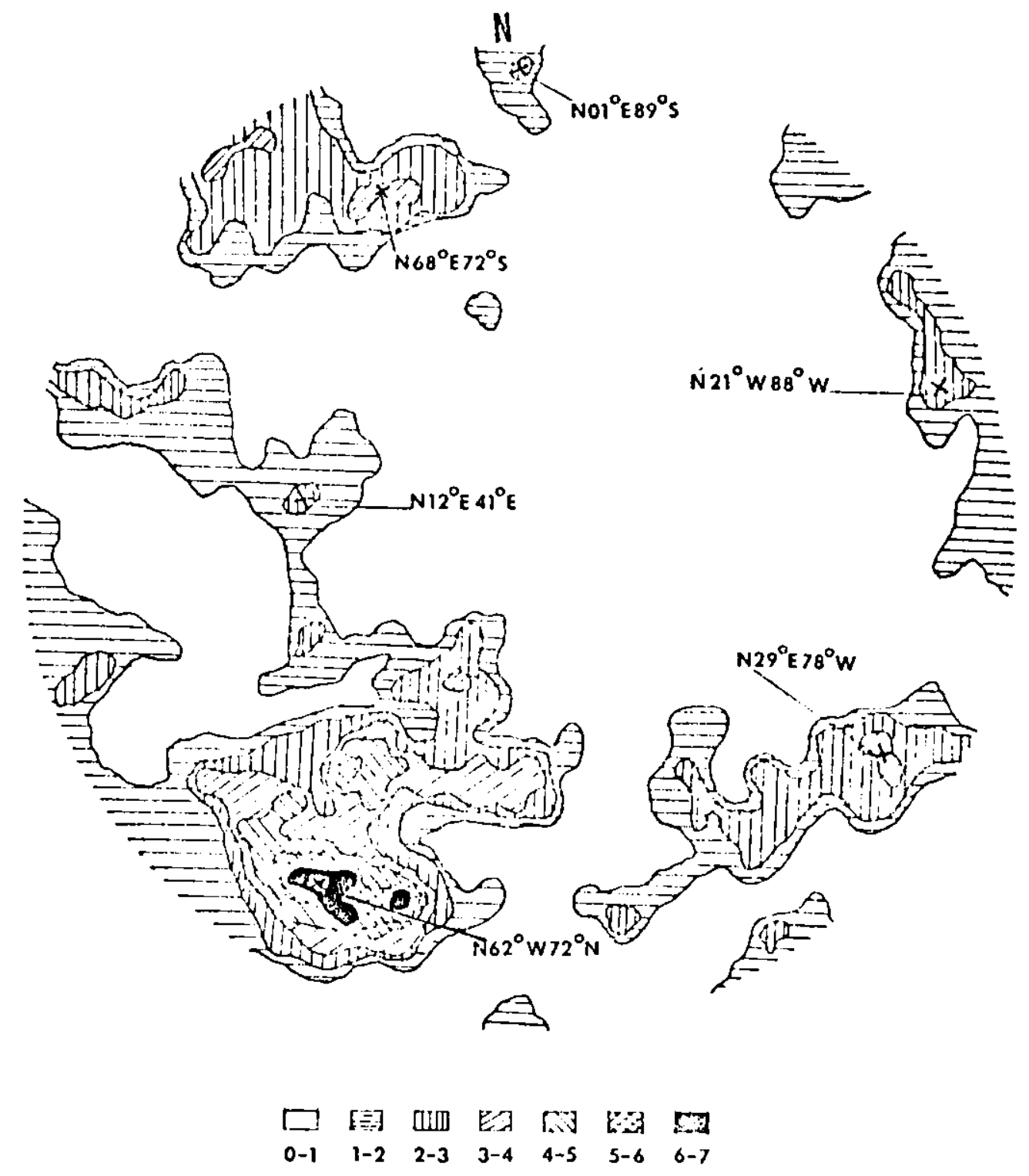

Fig. 1. Joints in equigranular and porphyritic phases of the quartz monzonite of the Idaho batholith 


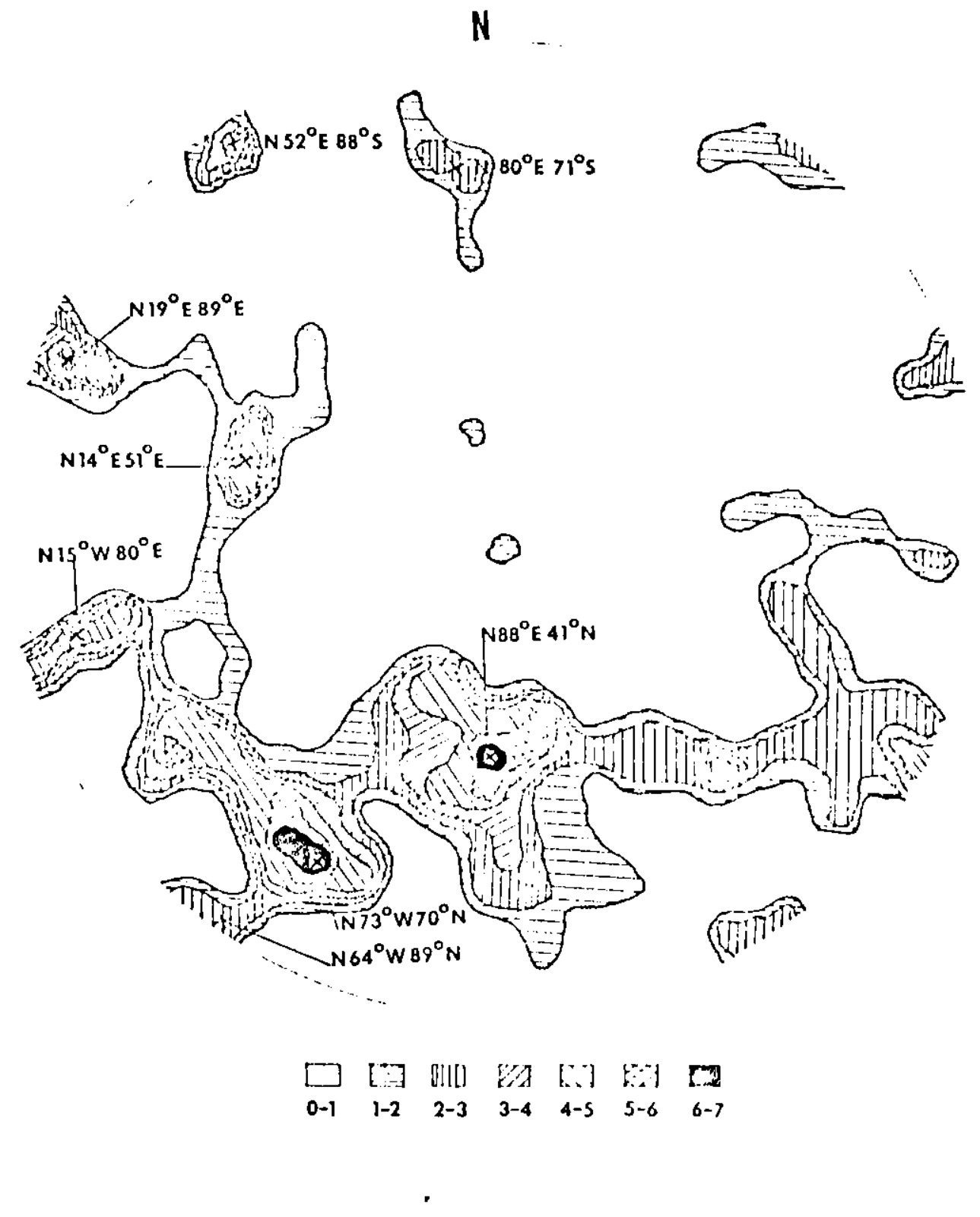

Fig. 2. Joints in the equigranular phase of the quartz monzontte of the Idaho batholith 


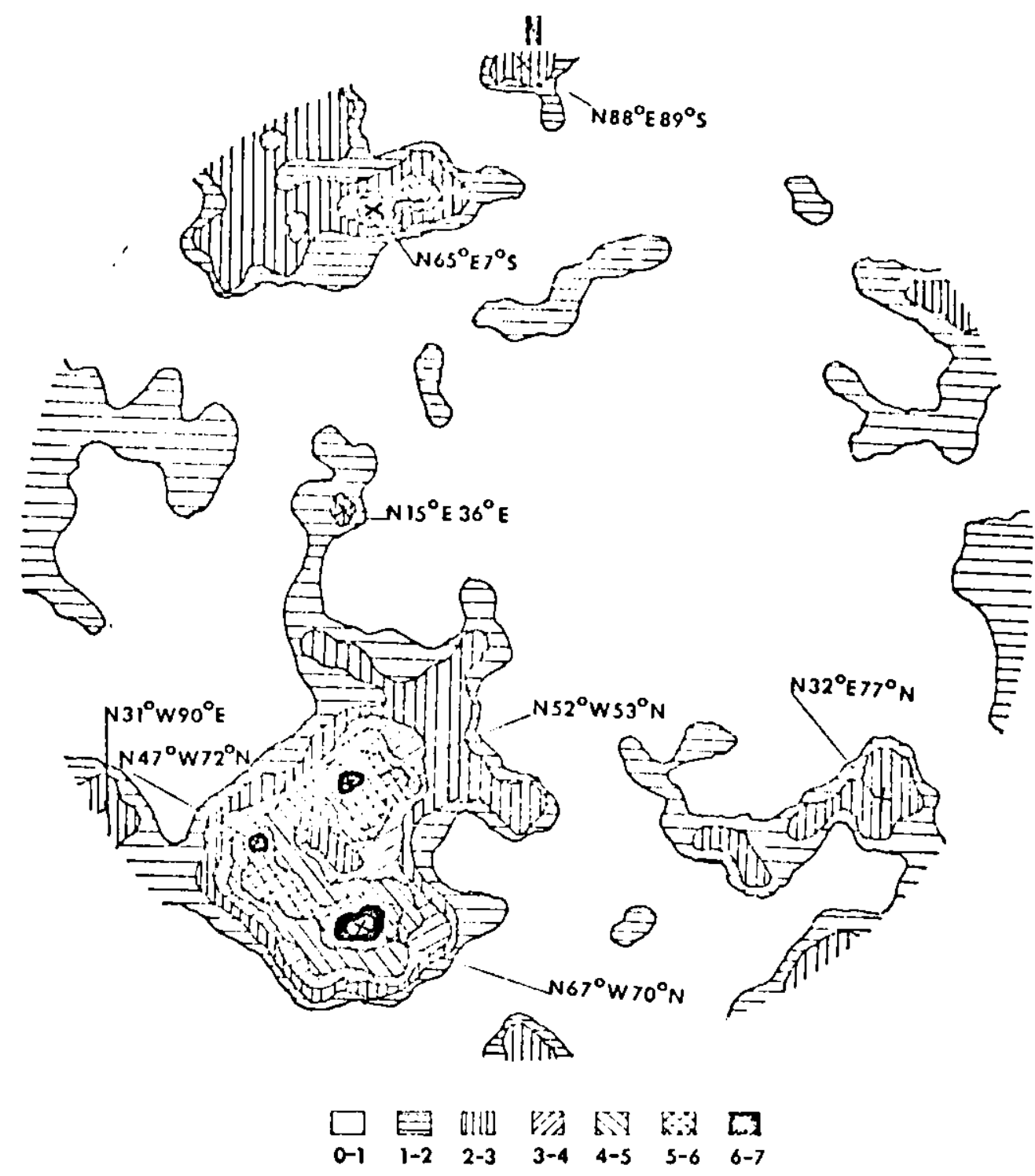

Fig. 3. Joints in the porphyritic phase of the quartz monzonite of the Idaho batholith 
A N. $52^{\circ}$ W. $53^{\circ}$ N. set of joints is found in the porphyritic quartz monzonite (fig. 3) and is physically similar to the N. $88^{\circ}$ W., $41^{\circ}$ N.bearing joints mentioned above. The two joint sets are probably related and indicate that joint trends tend to vary across the different phases of the quartz monzonite although they probably originated in the same stress field. The two phases were possibly intruded at slightly different times.

The other two joint sets are N. $67^{\circ}$ W., $70^{\circ}$ N. and N. $32^{\circ}$ E., $77^{\circ} \mathrm{N}$. The N. $32^{\circ}$ E., $77^{\circ}$ N. set is found along the eastern border of the Idaho batholith in the equigranular quartz monzonite and in the adjacent Wood River Formation, where four of the joints are pegmatite filled. This set occupies an attitude of extension that has persisted in the area from the late Cretaceous to post-Challis time.

Three other joint trends are observed in the stereonet projections and probably are primary in origin. These trends are: the N. $88^{\circ} \mathrm{E}$. , $41^{\circ} \mathrm{E}$. set which is best developed in the equigranular quartz monzonite (fig. 2); the N. $88^{\circ}$ E., $89^{\circ}$ S. set which is best developed in the porphyritic quartz monzonite (flg. 3); and the N. $21^{\circ}$ W., $88^{\circ}$ W. group observed in both quartz monzonite phases (fig. 1). The joints do not seem to indicate that the porphyritic and equigranular phases have been subjected to different stress fields.

Most of the above joints in the quartz monzonite were reactivated in the Tertiary by tensional forces that allowed ore-bearing fluids to enter them. This situation tends to suggest that stresses In 1ate-Challis time were approximately parallel to the Laramide trends.

Ten andesite dikes of Challis age have attitudes of N. $25^{\circ}$ E., $89^{\circ} \mathrm{W}$. or N. $86^{\circ}$ E., $88^{\circ}$ W. Eighteen rhyolite dikes have either the same two 
attitudes or a N. $64^{\circ}$ E., $89^{\circ}$ N, attitude. This latter tensional attitude is dissimilar to the others as pegmatite and aplite dikes do not appear to fill $1 t$, which indicates possibly that it is Challis related.

The joint trends approximately fit three fault trends found in the study area (Table 15). The joints therefore are reflections of the same stresses that were responsible for the formation of the faults. 
Table 15. Comparison of fault and joint trends found in the study area

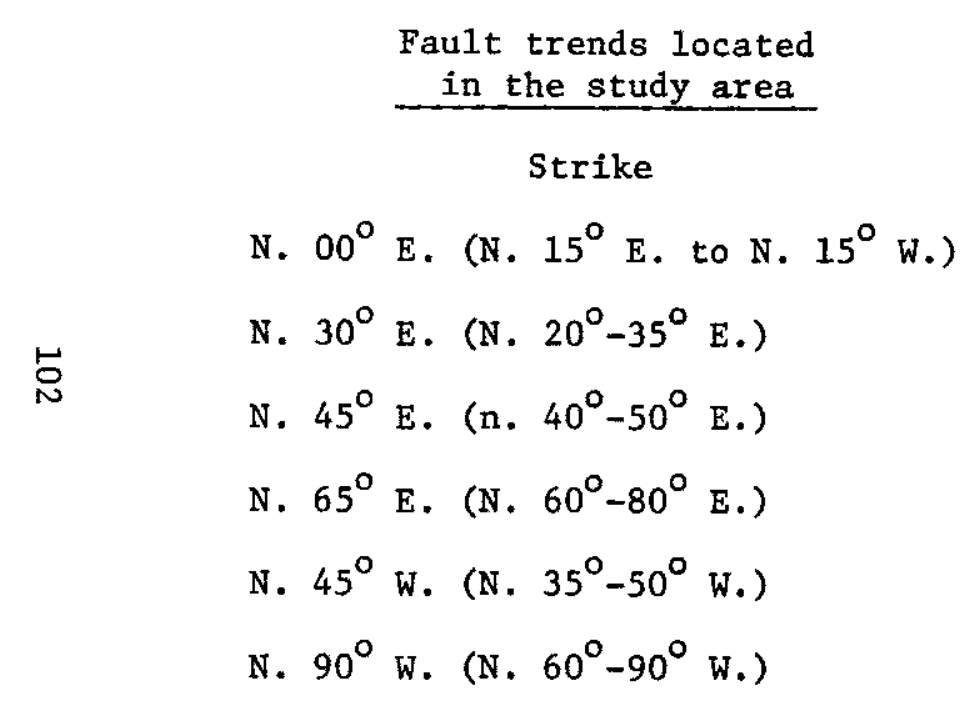

\begin{tabular}{lc}
$\begin{array}{c}\text { Joint trends equivalent } \\
\text { to the fault trends }\end{array}$ \\
observed in the study area \\
\hline Strike & Dip \\
N. $15^{\circ} \mathrm{E}$. & $36^{\circ} \mathrm{E}$. \\
N. $32^{\circ} \mathrm{E}$. & $77^{\circ} \mathrm{N}$. \\
N. $52^{\circ} \mathrm{E}$. & $88^{\circ} \mathrm{S}$. \\
N. $65^{\circ} \mathrm{E}$. & $70^{\circ} \mathrm{S}$. \\
N. $47^{\circ} \mathrm{W}$. & $72^{\circ} \mathrm{N}$. \\
N. $64^{\circ} \mathrm{W}$. & $89^{\circ} \mathrm{N}$. \\
N. $67^{\circ} \mathrm{W}$. & $70^{\circ} \mathrm{N}$. \\
N. $88^{\circ} \mathrm{E}$. & $89^{\circ} \mathrm{N}$. \\
N. $62^{\circ} \mathrm{W}$. & $72^{\circ} \mathrm{N}$. \\
N. $88^{\circ} \mathrm{E}$. & $41^{\circ} \mathrm{N}$.
\end{tabular}

Type of stress that opened the given trends (Choate, 1962)

Shear
Shear and Tension
Tension
Shear
Tension and Shear
Shear


There is considerable uncertainty about the origin of the urantum deposits in the Stanley Basin. The uranium veins in the quartz monzonite of the Idaho batholith clearly are epigenetic but they may be either hypogene (as Kern, 1959 and Choate, 1962 suggested) or supergene in origin; the bedded deposits in the arkoses of Coal Creek may be syngenetic (Choate, 1962) or epigenetic (Kern, 1959) and either hypogene or supergene (Choate, 1962). For both kinds of deposits the evidence of origin is inconclusive. In order to elucidate the origin of the uranium deposits a geochemical sampling and analytical program was designed at the start of the present study.

In view of the well-known association of alkalic volcanic rocks with high concentrations of uranium, and of the position of the Challis volcanic field that in early Tertiary time overlaid a deeply buried portion of a subduction zone (Lipman and others, 1971, 1972); the first geochemical consideration is the nature of the igneous rock series, calc-alkalic or alkalic, represented by the Challis Volcanics. Accordingly, 51 samples of volcanic rocks and Challis-related intrusions were collected and analyzed for major oxides contents, with the exception of iron oxides by XRF methods. Iron was determined separately by an emission spectrographic technique. The analytical results for the major oxides are not of high quality as the sum of the constituents varies from a low of 89.68 percent to a high of 105.00 percent. These erratic totals probably are partly the result of analyzing porphyritic rocks and partly the result of insufficient grinding, mixing, and fusion before analysis. From the 
tabulation of the analytical results (see Appendix table 1 ) it is seen that the sum of the major oxide constituents varies with the silica content; the lower totals correspond to the low-silica-bearing andesites, and the higher totals correspond to the high-silica rhyolites. As a result of this relationship, we adjusted, for each determination, the percentages of the major oxides to a total of 100 percent on a volatile-free basis. The adjusted oxide percentages are shown on Appendix table 1 . Although the adjusted values cannot be regarded as being very accurate the normative amounts based upon them agree quite well with our petrographic determinations (the norms are given in the lower part of Appendix table 1 ). An AFM plot (fig. 4) of the adjusted oxide values indicates that the Challis rocks fall into a calc-alkaline series. Calculation of the alkalilime index, the silica percentage where $\mathrm{CaO}$ content is equal to the combined $\mathrm{Na}_{2} \mathrm{O}$ plus $\mathrm{K}_{2} \mathrm{O}$ content, from the adjusted data in Appendix table 1 gives an index of 58 ; this value also indicates a calc-alkalic series (Carmichael and others, 1974, p. 48).

The adjusted $\mathrm{K}_{2} \mathrm{O}$ values of the Challis rocks in Appendix table 1 range from 2 to 5.6 percent and the $\mathrm{Na}_{2} \mathrm{O}$ values range from 1.4 to 4.1 percent. The $\mathrm{K}_{2} \mathrm{O} / \mathrm{Na}_{2} \mathrm{O}$ ratio in individual samples ranges from 2 to 5.4 and suggests a tendency towards $\mathrm{K}_{2} 0$ enrichment. This observation is supported by the An-Ab-Or diagram in Figure 5 where two samples (MAS 679 and 717, symbol $\mathrm{V}$ in the figure) from the tuff of Duffey Creek are K-rich rhyolites and over one-half of the samples of the andesites of Bonanza Peak and of Deadwood Creek (symbols $\mathrm{X}$ and $\mathrm{W}$ respectively) are also K-rich. The remainder of the samples is "normal" sub-alkaline rocks according to the subdivisions of Irvine and Baragar (1971, p. 539). The two andesite 
TERIARY DIAGRAM OF INTRUSIVE ANO EXTRUSIVE ROCKS IN THE CHALLIS VOLCANICS

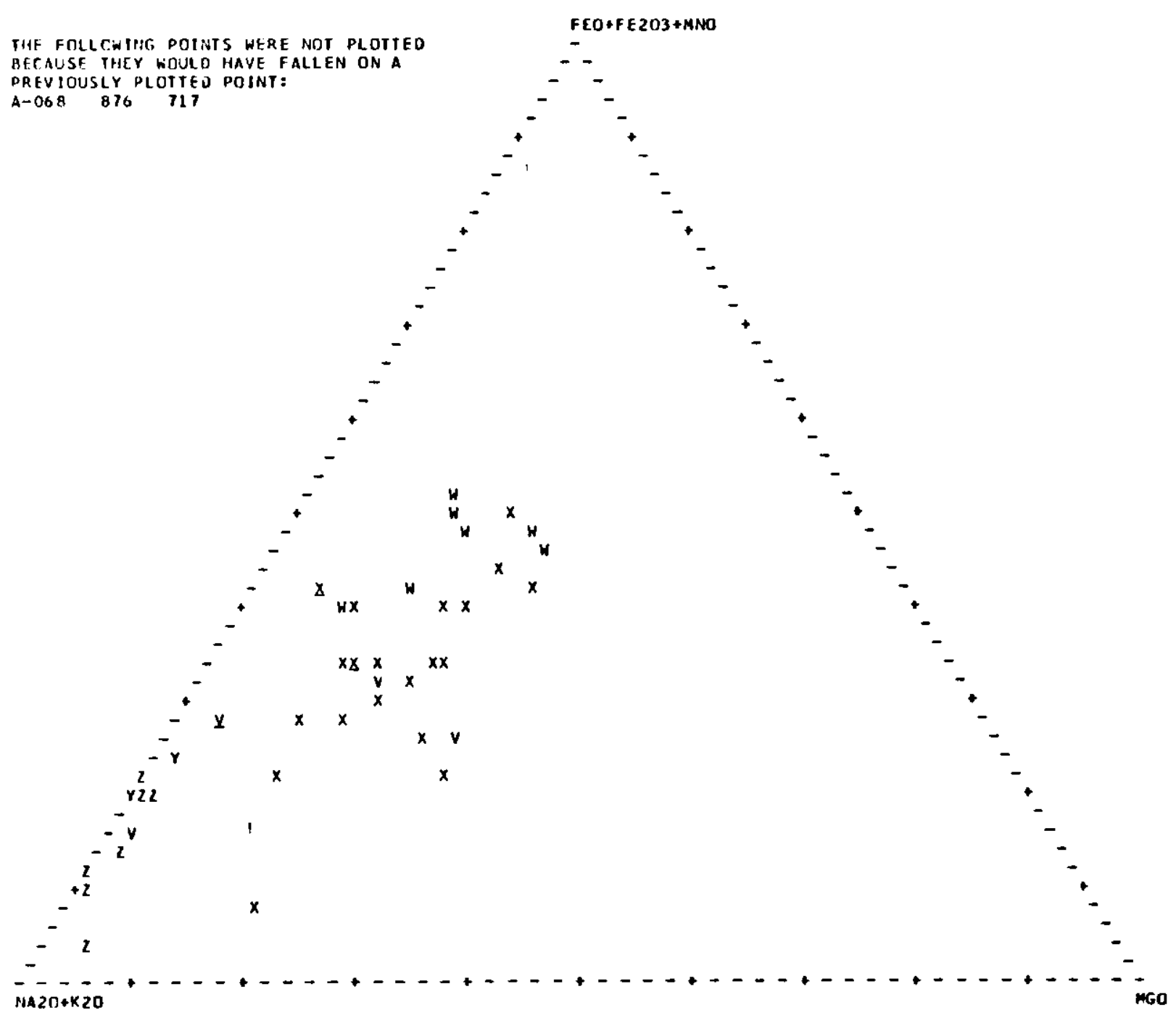

Figure 4. AFM diagram of Challis Volcanics and intrusive rocks.

Key to symbols: $\mathrm{X}$ is andesite of Bonanza Peak

$W$ is andesite of Deadwood Creek

$\mathrm{V}$ is tuff of Duffey Creek

$Z$ is rhyolite of West Fork

$\mathrm{Y}$ is rhyolite of McGowan Peak 
TER.NARY OIAGRAM OF INTRUSIVE AND EXIRUSIVE RUCXS IN IHE CHALLIS VOLCANICS

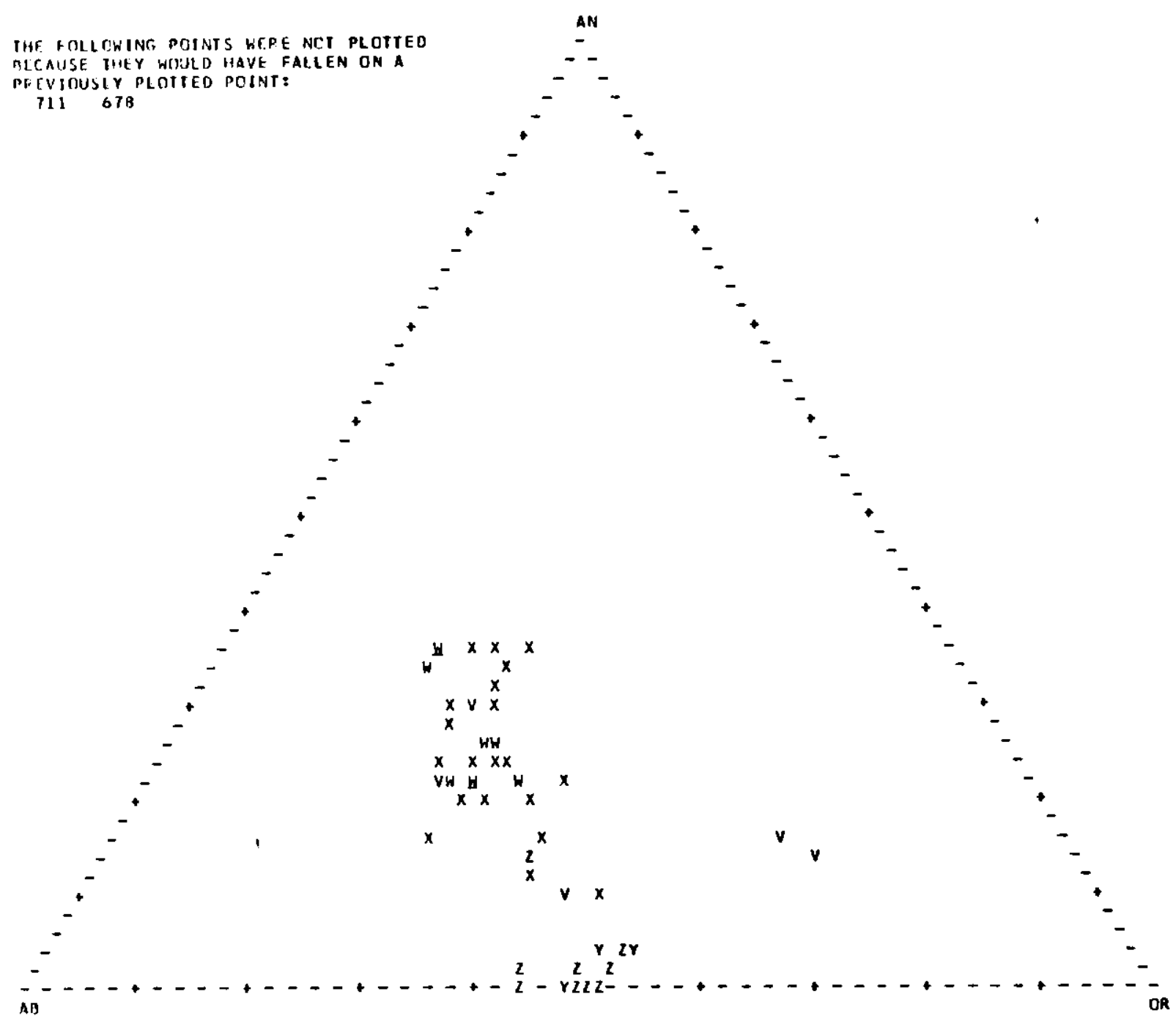

Figure 5. An-Ab-Or diagram of Challis Volcanics and intrusive rocks.

Key to symbols: $\mathrm{X}$ is andesite of Bonanza Peak

$\mathrm{W}$ is andesite of Deadwood Creek

$\mathrm{V}$ is tuff of Duffey Creek

$Z$ is rhyolite of West Fork

$\mathrm{Y}$ is rhyolite of McGowan Peak 
units, in general, have $\mathrm{K}_{2} \mathrm{O}$ contents in excess of 2.5 percent (see fig. 6) and, compared to andesites of other orogenic belts, are high-K andesites (Taylor and others, 1969). Their relatively high $\mathrm{Pb}$ content (see Appendix table 2) is characteristic of high-K andesites.

In summary, the Challis Volcanics are members of a calc-alkalic series that is slightly enrtched in potassium. The depth to the Eocene-age subduction zone in central Idaho postulated by Lipman and others (1972) would indicate a more alkalic composition for the Challis rocks than that present. In central Montana a supra-subduction zone position similar in depth to that in central Idaho gave rise to the Judith Mountains alkalic volcanic field.

The $\mathrm{U}_{3} \mathrm{O}_{8}$ and Th contents of the Challis Volcanics and quartz monzonites of the Idaho batholith shown in Appendix table 3 are compared with data typical of other calc-alkalic magma series and granitic batholiths (Taylor and others, 1969; Zlelinskt and others, 1977; Levinson, 1974). The background values of the quartz monzonites are about normal; high values of $\mathrm{U}_{3} \mathrm{O}_{8}$ are only obtained from samples collected near uranium mineralization. The andesites of Bonanza Peak are significantly enriched in $\mathrm{U}_{3} 0_{8}$ and Th when compared to other high-K andesites by Taylor and others (1969). The average $\mathrm{U}_{3} \mathrm{O}_{8}$ content of $4.1 \mathrm{ppm}$ and Th content of $10.3 \mathrm{ppm}$ are high compared to typical values. The andesites of Deadwood Creek contain only normal abundances of $1.0 \mathrm{ppm}_{3} \mathrm{O}_{8}$ and $7.7 \mathrm{ppm}$ Th. The tuff of Duffey Creek at an average of $5.5 \mathrm{ppm} \mathrm{U}_{3} \mathrm{O}_{8}$ and $19.9 \mathrm{ppm}$ Th; the rhyolite of West Fork

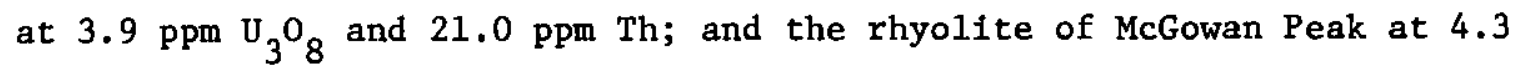
ppm $\mathrm{U}_{3} \mathrm{O}_{8}$ and $20.8 \mathrm{ppm}$ Th all appear to contain normal abundances. The results of the total count radiometric field survey (see p1. 3 for locations and measurements) do not indicate any unusually high readings 
X-Y VARIATION DIAGRAM OF tNTRUSIVE ANU EXTRUSIVE ROCKS IN IHE CHALLIS VOL.

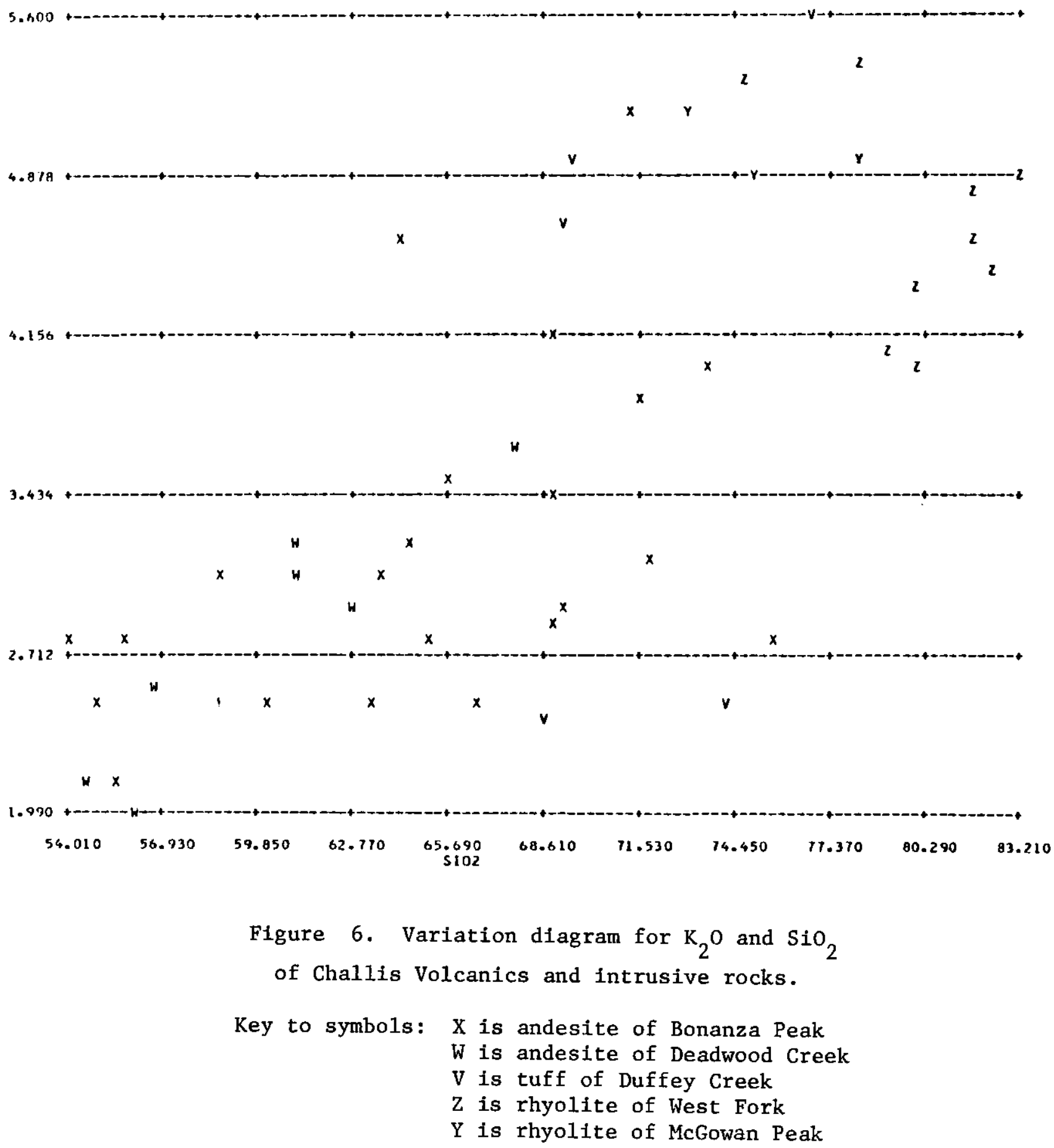


except near known uranium mineralization. A statistical summary of the measurements arranged according to type of country rock is shown in table 16. The arkoses and sandstones of Coal Creek has the highest mean radioactivity because the mean is influenced by very high measurements near mined-out uranium orebodies. The rhyolites of West Fork and McGowan Peak and the quartz monzonites of the Idaho batholith have means of 130 counts per second. The mean of the quartz monzonite phases probably is influenced by the presence of weak epigenetic uranium mineralization. The radiometric measurements and the analytical results for uranium do not disclose that one lithology is a more likely source for the uranium in the deposits than other lithologies. The present uranium content is sufficiently high in all the Challis and Idaho batholith rocks to enable any 11thology to be a potential source by the processes of weathering and leaching. The possible loss of uranium from glassy volcanic rocks (Z1elinski and others, 1977) and from granitic bodies by weathering enable either the Challis Volcanics or the Idaho batholith to be possible donors of uranium to the Stanley Basin deposits.

Carbonaceous material of plant origin is closely associated with the uranium orebodies in the arkoses of Coal Creek, and in many places its presence appears to have controlled the precipitation of uranium from solution. There are other units in the Challis Volcanics that are carbonaceous but are not associated with high concentrations of uranium. These units include the upper tuffaceous sandstones of Coal Creek which in some fault blocks are about 100 to 200 feet stratigraphically above the arkoses and the orebodies. In other fault blocks andesites of Bonanza Peak and tuffs of Duffey Creek overlie the arkoses. Also, there is a sequence of carbonaceous 
Table 16. Total-count radioactivity measurements for all geologic units

苂

Mean

Standard

deviation

Maximum

Minimum

Number of determinations
Values are in counts per second

\begin{tabular}{|c|c|c|c|c|c|c|c|}
\hline $\begin{array}{l}\text { Wood River } \\
\text { Formation }\end{array}$ & $\begin{array}{l}\text { Quartz } \\
\text { monzonite }\end{array}$ & $\begin{array}{l}\text { Arkoses and } \\
\text { sandstones } \\
\text { of Coal Creek }\end{array}$ & $\begin{array}{c}\text { Andesite flows } \\
\text { of Bonanza } \\
\text { Peak }\end{array}$ & $\begin{array}{c}\text { Tuffs in Andesites } \\
\text { of Bonanza } \\
\text { Peak }\end{array}$ & $\begin{array}{l}\text { Tuff of } \\
\text { Duffey } \\
\text { Creek }\end{array}$ & $\begin{array}{l}\text { Rhyolite } \\
\text { of West Fork of }\end{array}$ & $\begin{array}{l}\text { Rhyolite } \\
\text { McGowan } \\
\text { Peak }\end{array}$ \\
\hline 90 & 130 & 490 & 90 & 70 & 105 & 130 & 130 \\
\hline 20 & 50 & 750 & 20 & 10 & 35 & 40 & 30 \\
\hline 120 & 500 & 3000 & 200 & 80 & 180 & 200 & 220 \\
\hline 50 & 50 & 50 & 40 & 50 & 55 & 80 & 80 \\
\hline 13 & 204 & 25 & 186 & 13 & 43 & 130 & 73 \\
\hline
\end{tabular}


and tuffaceous sedimentary beds on Loon Creek Pass 8 miles to the northeast of the study area. This sequence probably correlates stratigraph1cally with the upper part of the tuff of Duffey Creek and lies close to a number of domes and intrusions of rhyolites similar to those of West Fork and of McGowan Peak. Desplte these seemingly favorable characteristics the sequence is not abnormally high in uranium content.

These observations make it clear that the source of the uranium in the orebodies is unlikely to be the overlying volcanic strata and that vertical downward migration of uranium-enriched groundwater is not involved in ore deposition in the Stanley Basin. It is possible that there was 1ateral migration of solutions from Challis volcanic rocks on the west or northwest that subsequently have been removed by erosion. The presence of molybdenum in the uranium orebodies in the arkoses of Coal Creek (0.H. Rostad, oral communication, 1978) Indicates that ore transportation was by oxfdizing alkaline solutions. Both uranium and molybdenum could be released from the Challis Volcanics or batholithic rocks by alkaline surface waters and groundwaters.

One possible model to account for the origin of the deposits is that during early Tertiary time the Stanley area was on the eastern side and in the rain shadow of a north-south range of volcanic mountains. Surface waters and groundwaters in the valleys might have been alkaline and high in dissolved bicarbonate. Uranium would be kept in solution as bi- and tri-carbonate complex ions and would be precipitated by reducing conditions caused by bacteria colonies associated with the plant remains in the arkoses. A similar process is believed to occur at present in surface waters draining the Sawtooth batholith (Killsgaard and others, 1970) 
and in surface waters and groundwaters of the Okanagan Valley in southcentral Britısh Columbia (Culbert and Leighton, 1978). At Stanley Basin the uraniferous groundwater flow regime might have been activated either by the uplift of the Idaho batholith, by the emplacement of Challis Volcanics related intrusions; or by the emplacement and subsequent uplift of the Sawtooth batholith of late Eocene age. The uranium content of the Sawtooth batholith (Kiilsgaard and others, 1970) is higher than the average granite and as much as two times more than the Idaho batholith rocks in the Stanley Basin. Also, a large proportion (about 70 percent) of the uranium is leachable by a $\left.2 \mathrm{~N}^{\left(\mathrm{NH}_{4}\right)}\right)_{2} \mathrm{SO}_{4}$ solution and, at present, natural leaching and weathering of the batholith is producing concentrations of uranium in stream sediments and in bog deposits that are rich in organic matter (Killsgaard and others, 1970, p. D35). Similar processes could have been active in the Eocene but there is a long interval of time between the deposition of the organic trash in the arkosic sediments and the intrusion of the Sawtooth batholith. The longer the time interval the less likelihood that the organic material was capable of fixing the uranium.

A second model of a hypogene, epigenetic origin for the deposits is not negated by the evidence. A hydrothermal, convective system could have been initiated at any time following the deposition of the arkoses of Coal Creek. Uraniferous hydrothermal solutions in the system could mix with supergene meteoric waters and pitchblende deposition could take place under relatively low-temperature and low-pressure conditions in either the ascending side or the descending side of the convection cell. A transition to processes operating during the first model is possible on the descending side of a convective system. 


\section{URANIUM DEPOSITS}

\section{Production}

The first uranium claims in the Stanley area were the Fool Proof and Abbie Lou claims, which were staked in September 1955. Many other claims were staked soon after. Production began with the shipment of ore in 1958 and ceased in 1962. Production figures are not avallable after 1960, however, the mines in the area have been inactive since the early 1960's. Interest in the area has been renewed in the past couple of years due to the energy crisis and the need to locate new sources of uranium.

Table 17 summarizes Choate's (1962) data on the production of uranium from the Stanley area. Stockpiled ore is included in the table because it is thought most of the stockpiled ore was shipped to the mills at a later date. However, since the information on the stockpiled ore is not precise, it is not included in calculating the overall averages for the area.

The total production of uranium from the Stanley area through the end of the mining season of 1960 was 7,767 tons of ore with an average grade of 0.18 percent $\mathrm{U}_{3} \mathrm{O}_{8}$. Of the total, 6,978 tons came from deposits in sedimentary rocks and 789 tons came from vein deposits in Idaho batholith rocks. The average grade for both the vein and the bedded deposits was 0.18 percent $\mathrm{U}_{3} \mathrm{O}_{8}$. 
Table 17. Uranium production, Stanley Area, Custer County, Idaho

Property

ightning No. 2

Lightning No. 2

Lightning upper pit

Hardee No. 3

Baker pit

Deer Strike-E1k

Deer Strike-E1k

Coal Creek No. 1

Coal Creek No. 4

East Basin No. 1

East Basin No. 1

Shorty No. 2

Shorty No. 2

Shorty No. 2
Year

Vein Deposits
Production

(tons)
Grade

$\left(\% \mathrm{U}_{3} \mathrm{O}_{8}\right)$
1959

1960

1958

1959

Tota1

stockpiled

Bedded Deposits
271

420

48

50

789

30

835

1,060

1,360

450

1,100

773

1,400

Total

6,978

stockpiled

stockpiled
$1,000-1,500$

TOTAL $\quad 7,767$
0.15

0.18

0.28

0.17

0.18

$0.30-0.40$

Combined bedded and vein deposits

$\begin{array}{llll}\text { TOTAL } & 7,767 & 0.18\end{array}$

Data from Choate (1962). 
Mines and Prospects

Uranium in the study area occurs as two types of deposits: bedded deposits in sedimentary rocks, and vein deposits in Idaho batholith rocks. The sedimentary deposits occur in the arkosic unit of the arkoses and tuffaceous sandstones of Coal Creek and were deposited near the basement of Idaho batholith rocks. The vein deposits were formed by deposition of primary uranium minerals in fractures in the quartz monzonite of the Idaho batholith. Secondary uranium minerals are present in both types of deposits.

An attempt was made to visit a11 the major workings in the area. However, since the last work on many of these deposits was about 15 years ago, the amount of information obtainable was sometimes limited. In all localities, slumping obscured the relationships and it is suspected that leaching may have reduced the amount of radioactivity observed in some localities. Kern (1959) and Choate (1962) both give descriptions of the deposits at the time they were being worked.

\section{Vein Deposits}

Choate (1962) lists two types of vein deposits that are found in the granitic rocks of the Stanley uranium area: those with substantial amounts of introduced quartz and those with little or no added quartz. Only the latter type of veins were found in the study area, although small chalcedony stringers were found at one locality (the Bell Cross pit) and silicified dikes were found at two other localities (the $H$ and $M$, and the Main Diggings claims). Most of the vein uranium deposits in the area are located in fractures or faults and are accompanied by little or no intro- 
duced silica. Vein deposits appear to be found only in the quartz monzonite of the Idaho batholith. Uraninite and autunite were the minerals observed to be present in the vein deposits.

\section{Be11 Cross}

The Be11 Cross pit is located in about the center of sec. 10, T. 11 N., R. 13 E.; it was the only major development in the vicinity of the Be11 Cross claims, which form a strip along the southern slope of Potato. Mountain.

The country rock is a medium- to coarse-grafned quartz monzonite that is usually highly weathered. The rock has been intruded by aplite and pegmatite dikes. A few small veinlets of dark-colored chalcedony were also present. Choate (1962) states that the mineralization in the pit is uraninite disseminated in minor amounts in the chalcedony stringers; enrichment of the uraninite occurs where the chalcedony veinlets intersect the aplite and pegmatite dikes.

Radioactivity measured at the Be11 Cross pit was about $500 \mathrm{cps}$, which is approximately five times the background radioactivity for the country rock. Because of the low radioactivity anomaly and because of the small amount of mineralization observed in the pit, it is doubtful whether further work w111 uncover significant ore at the Bell Cross pit. $\mathrm{H}$ and $\mathrm{M}$

Development on the $H$ and $M$ claims consists of seven bulldozer cuts; one above the other on the southeast slope of Potato Mountain. The pits are located in the $\mathrm{SE} 1 / 4 \mathrm{sec}, 3, \mathrm{~T} .11 \mathrm{~N} ., \mathrm{R} .13 \mathrm{E}$. The country rock is a weathered, coarse-grained quartz monzonite. The most prominent rock exposed in the pits is a highly silicified aplite dike. Radioactivity measured in the pits of the $\mathrm{H}$ and $\mathrm{M}$ claims was between 140 and $150 \mathrm{cps}$, and about 50 
percent above the background radioactivity of the country rock. No uranium mineralization was observed in the pits.

Main Diggings

The Main Diggings claims are located in the NW $1 / 4 \mathrm{sec} .11, \mathrm{~T} .11 \mathrm{~N}$. , R. 13 E. on the oval shaped hill that separates the two forks of Sawmi11 Creek. Choate (1962) described the rocks exposed on the claim as "porphyritic and nonporphyritic, quartz monzonite...intruded by pegmatite and rhyolite dikes. Quartz monzonite exposed in cuts along the west slope [of the hill] has been partially silicified." The rocks on this claim were poorly exposed in the summer of 1977 due to slumping on the faces of the cuts; the only rock types observed were weathered quartz monzonite (nonporphyritic) and silicified aplitic dike rocks. Kern (1959) stated that "the geological relationships on the Main Diggings claims are similar to those on the Bell Cross claims: uranium-bearing chalcedony veinlets in silicic rocks are the source of the radioactivity." The radioactivity measured on this claim was small, ranging between 100 and 300 cps, or a maximum of about three times the background radioactivity of the country rock.

Baker and Potato Hi11

The Baker and Potato Hill claims are located near the NW corner of sec. 1, T. 11 N., R. 13 E. A pit some 170 feet northwest of the section corner and at the end of the Sawmill Creek road exposed a heavily mineralized fault striking about $\mathrm{N} .70^{\circ} \mathrm{W}$. and dipping about $72^{\circ} \mathrm{N}$. Autinite is concentrated in the fault zone and disseminated in the surrounding rock, which is a highly weathered quartz monzonite. Choate (1962) stated that the ore zone exposed at the Baker pit was thicker and contained more sec- 
condary uranium mineralization than any other mineralized zone in the Stan1ey area.

Scintillometer readings gave a maximum value in excess of 10,000 cps in the fault zone itself. Readings of several thousand counts per second were determined for areas that had disseminated autunite outside the fault zone. Even outside the zone of visible mineralization, scintillometer readings taken in the pit gave values several times that of the background radioactivity (up to $500 \mathrm{cps}$ ). Although the high radioactivity values were not so readily apparent in rocks that had a cover of soil, the high radioactivity could be traced about 200 feet above the pit before the readings became indistinguishable from the background readings. The strong radioactivity anomaly and the high concentration of uranium minerals indicate that further exploration should be done on this property.

Lightning

The Lightning claims are part of the Lightning, Copperite, and Aspen groups that form a strip along Basin Creek from Kelley Creek to Little Basin Creek, and a strip that extends up Hay Creek. Workings in the granitic rocks on the Lightning property are described by Choate (1962) as the Lightning No. 2 bulldozer cut and adit, the Lightning No. 1 adit, and the Lightning upper pit. In the summer of 1977 , both adits were closed by materlal slumped over the presumed locations of their entrances.

The Lightning No. 2 workings are on the southside of Hay Creek, about thirty feet above the creek and about 500 feet east of Basin Creek. The rock exposed in the cut is a coarse-grained quartz monzonite with prominent joints. Attitudes of the joints are: N. $18^{\circ}$ E., $84^{\circ}$ S.; N. $50^{\circ} \mathrm{W} . ; 55^{\circ} \mathrm{N}$, and 
N. $59^{\circ}$ W., $40^{\circ} \mathrm{S}$. Movement appears to have occurred along some but not

a11 of the northwest-trending joint surfaces. Choate (1962, p. 48-9) des-

cribes the mineralization at the Lightning No. 2 workings as follows:

Mineralization is concentrated along a series of parallel fractures within a fault zone that strikes N. $38^{\circ} \mathrm{W}$. The main fractures dip $65^{\circ}$ northeast. Little gouge occurs in the fractures but several fractures have slickensided walls...0regrade mineralization is restricted to a steeply pitching shoot 25 feet long and 4 to 5 feet wide. The shoot is tabular stockwork composed of many thin but closely spaced veins and veinlets. Pitchblende formed partially by open filling and partially by replacement. Former openings filled by pitchblende consist of the N. $38^{\circ}$ W.-trending faults, narrow breccia zones along the faults, and numerous small fractures sub-parallel to the faults. The thickest vein observed was 1 inch thick. Throughout the shoot, veinlets diverge from the narrow pitchblende veins to form miniature "horsetail" structures. Ore grade has increased with depth....The ore shoot on the Lightning No. 2 contains the highest-grade uranium mineralization yet exposed in the granitic rocks. Higher-grade ore should be present in the unaltered zone below the water table.

Scintillometer readings from the rocks exposed near where the adit opening is belleved to have been located gave readings up to $1,000 \mathrm{cps}$, and possible uraninite mineralization was observed on some of the joint surfaces. Further work on this property would seem justifiable.

The Lightning No. 1 adit was located about 820 feet north-northwest of the Lightning No. 2 workings and about 100 feet above Basin Creek. The adit was located along the contact between the quartz monzonite and a dike of the rhyolite of McGowan Peak; rocks along the contact are intensely sheared for about 6 inches. According to Choate (1962), the fault in the adit had a strike of $\mathrm{N} .67^{\circ} \mathrm{E}$. and dipped $65^{\circ}$ southeast. The rocks exposed at the surface showed the shear zone as almost vertical, with a dip of 86 degrees to the northwest. Scintillometer readings gave a value of 140 cps in the zone near the contact between the dike and the batholith rocks. No mineralization was observed at the surface, and Choate (1962) 
states that only one probe hole in the adit contained ore-grade mineral1zation.

The Lightning upper pit is located upslope and about 400 feet to the southeast of the Lightning No. 1 workings. Choate (1962, p. 50) describes the mineralization at the Lightning upper pit as follows:

Mineralization occurs along a fault zone with an attitude N. $60^{\circ}$ W., $70^{\circ}$ northeast. Fractures within the zone are spaced from 1 inch to 1 foot apart.... Exposed urantum minerals are secondary and occur mainly as coatings on fractures. Childs [Henry Childs of Hailey, who was developing the Lightning No. 2 in 1960] stated that the shipped ore contained mostly secondary yellow uranium minerals, but that some sooty pitchblende was uncovered at the base of the pit just before mining was halted in 1958.

No mineralization was observed at the pit in the summer of 1977 , because large numbers of joint blocks from the heavily jointed rocks at the back of the pit had fallen across the floor of the pit. However, scintillometer readings gave values of about $400 \mathrm{cps}$ (four times above background), indicating the presence of at least some mineralization.

Alta

Partly filled prospect pits and bulldozer cuts are visible on the property. Thin uranfferous chalcedony veins occur adjacent to pegmatite dikes in a N. $53^{\circ}$ E., $59^{\circ}$ S.E.-trending reverse fault in porphyritic quartz monzonite. The chalcedony veinlets contain stibnite crystals up to $4 \mathrm{~mm}$ in length. A value of 1.23 percent $\mathrm{U}_{3} \mathrm{O}_{8}$ (MAS sample no. 697) was obtained from one velnlet. Trace element analysis of this sample gave high values for $\mathrm{Sb}, \mathrm{As}, \mathrm{Mo}, \mathrm{Zn}, \mathrm{Cu}$ and $\mathrm{Sn}$ (see Appendix table 2). Scintillometer measurements up to 2,000 cps were recorded.

Sedimentary Deposits

Uranium deposits in the sedimentary rocks are confined to the lower unit of the arkoses and tuffaceous sandstones of Coal Creek. AlI the 
arkosic rocks containing uranium were found on or close to the contact with the porphyritic quartz monzonite. Choate (1962, p. 32) indicates that the uranium is strictly associated with carbonaceous beds. In describing the uranium-bearing rocks, he states:

Carbonaceous material in the sedimentary rocks consists of finegrained "trash" that fills voids and pores; scattered, vitrain1zed, wood fragments; thin, concordant, vitrain seams in mudstone beds; and intercalated beds and lenses of lignite, subbituminous coal, and vitrain. Uranium is intimately associated with carbon. Most ores are dark gray mudstones or arkosic sandstones in which uranium is disseminated in the carbon-rich matrix. The richest ore consists of vitrainized, fossilized wood fragments and branches.

The only uranium mineral observed in any of the sedimentary deposits was a bright yellow secondary mineral: Choate (1962) indentifies this minera1 as meta-autunite on the basis of X-ray work done by the AEC. Other uranium minerals Choate identifies from $\mathrm{X}$-ray powder-diffraction photographs are uraninite and coffinite.

Deer Strike and Elk

The Deer Strike No. 1 and No. 2 claims and the Elk No. 1 claim are located in the SW $1 / 4$ sec. 15 and the SE $1 / 4 \mathrm{sec} .16$, T. $11 \mathrm{~N} .$, R. $14 \mathrm{E}$. Workings on the property consist of an adit and five drilling benches. The entrance to the adit is in the $N E 1 / 4$ of the $S E 1 / 4$ of sec. 16 .

Mining was done from a fault-bounded block of the lower unit of the arkoses and tuffaceous sediments of Coal Creek. Choate's (1962, p. 61) description of the underground relations is as follows:

The down-faulted block is probably a graben with minor displacement on its southwest side and major displacement on its northeast side. Overburden covers most bedrock; contacts are not exposed in natural outcrops. Good rock exposures in the complexly faulted graben (?) exist only in underground workings and in surface bulldozer cuts. Logs of over 35 churn-drill holes sunk on the three claims, aided geologic interpretation. 
The only fault bounding the graben (?) exposed to date occurs in the main adit 102 feet from the portal. Fault attitude in N. $69^{\circ}$ E. $57^{\circ}$ northwest; slickensides bear N. $77^{\circ}$ W., and plunge $34^{\circ}$ northwest. The fault that forms the northeast side of the graben (?) Is not exposed; however, it passes between holes 29 and $34 \ldots$... Hole 34 has its collar at elevation 6,950 feet and was drilled entirely in quartz monzonite. In hole 29,145 feet to the south, quartz monzonite was penetrated at elevation 6,762 feet. From these data, it is inferred that the fault is steeply dipping and that a minimum vertical separation of 188 feet exists. The fault probably passes between holes 36 and 33 and between holes 30 and 34 ; if so, the fault strikes northwest.

Medium- to coarse-grained arkosic sandstones were observed in six small outcrops along the drilling benches. Choate (1962, p. 61-3) gives a detailed description of the rocks he observed underground. He states that the richest ore occurred at the contact between the arkoses and the porphyritic quartz monzonite, and that the uranium is preferentially concentrated in the more carbon-rich beds.

Radioactivity measured near the entrance of the mine in the summer of 1977 was $2,000 \mathrm{cps}$. Measurement of an exposure in a road cut some 350 feet to the northeast still showed a reading of $200 \mathrm{cps}$, which is about 2-1/2 times the values obtained for unmineralized rocks of the lower unit of the arkoses and tuffaceous sandstones of Coal Creek. Little Joe

The Little Joe claims are located in the W1/2 sec. 16 and the E1/2 sec. 17, T. 11 N., R. 14 E., near the top of the ridge east of Coal Creek. The claims border on the Elk No. 1 claim to the south. Choate (1962) notes the development on the property as three large pits and several small cuts; no ore-grade mineralization was encountered. By the summer of 1977 much slumping had occurred in the cuts and, in most places, a thick growth of small trees was growing over any exposed soil. Rocks exposed in the pits are conglomerates, coarse-grained sandstones, and mudstones of the lower unit of the arkoses and tuffaceous sandstones of Coal Creek. 
Lightniñ No. 3

The Lightning No. 3 development is located in the NE $1 / 4$ sec. $1, T$.

11 N., R. 13 E., about 1,600 feet up Hay Creek from Basin Creek, and about 200 to 300 feet above Hay Creek. Development consists of seven drill

benches. In the summer of 1977, two exposures were found along these benches, but in most cases, soll covered whatever rocks may once have been exposed and numerous small pine trees were growing on several of the benches. The arkosic sedimentary rocks appear to be bounded on both sides by faults; to the west, the rocks appear to be in fault contact with the porphyritic quartz monzonites of the Idaho batholith. To the east, the fault contact is with the andesite of Bonanza Peak. Choate described the relationships he observed on the property as follows (1962, p. 63-4):

Sedimentary beds strike N. $60^{\circ}$ W., generally paralleling contour lines, and dip $18^{\circ}$ N.E. into the hill... The quartz monzonitesediment, depositional surface forms a relatively flat plane, indicating that the local area of sediment deposition had low relief... Minerallzation is confined to a buried, former stream channel. Stream channel base was cut in quartz monzonite... [and] parallels a zone of closely-spaced fractures in quartz monzonite. Fractures have an attitude N. $25^{\circ}$ W., $75^{\circ}$ S.W. and are spaced from 6 inches to 1 foot apart...most mineralization occurred in a broad meander of the stream...Drill cuttings indicate that the channel fill is composed of intercalated beds of mudstone, sandstone, arkose, lignite, and minor conglomerate...Mineralization occurs in multiple horizons as rich, but thin, beds and lenses in carbon-rich sediments... Most beds are only a few inches thick. Probing records indicate that the richest mineralization occurred just above the quartz monzonite contact; however, mineralized beds occur up to 20 feet above the contact.

No mineralization was observed on the property in the summer of 1977 but scintillometer readings of 300 and $900 \mathrm{cps}$ were determined for the two outcrops in the drill benches. According to Choate (1962), the mineralized zone on the Lightning No. 3 property did not constitute an orebody. 
Coal Creek

The Coal Creek claims are located along the outcrop zone of the arkosic unit of the arkoses and tuffaceous sandstones of Coal Creek on the slopes to the east and west of Coal Creek. The claims are located mainly in sec. 16, T. 11 N., R. 14 E. Development consists of open pits on Coal Creek No. 1 and Coal Creek No. 4.

The Coal Creek No. 1 pit is located about 200 feet above Coal Creek in the SE $1 / 4$ of the NW $1 / 4$, sec. $16, T .11 \mathrm{~N} .$, R. 14 E. The dominant rock types exposed at this mine are coarse-grained arkosic sandstones and conglomerates with clasts up to 6 or 8 inches in diameter. The conglomerates are often heavily stained with iron. Some finer grained sediments are also present as well as thin seams of coal overlying the conglomerate bed near the base of the arkosic unit.

Choate (1962, p. 66) describes the occurrence of the ore in the Coal

Creek No. 1 pit as follows:

Ore occupied two channels in the former stream. The two channels were partly separated by a low ridge. Average thickness of ore in the channels was 5 feet; ore over the saddle was 1 to 2 feet thick... Carbonaceous material is present as fine-grained trash disseminated throughout the conglomerate matrix, and as 1ignite, sub-bituminous coal, and vitrain seams overlying the conglomerate...The highest-grade ore occurred in a grayish-black layer 6 inches to 1 foot thick, at the base of the main channel.

Scintillometer readings on the rocks in the pit gave values between 800 and 1,600 cps.

The Coal Creek No. 4 pit is located about 900 feet to the southeast and uphill from the Coal Creek No. 1 pit. During the summer of 1977 the rocks in the pit were very poorly exposed due to soll slumping over the faces of the pit. The rocks exposed indicate that the unit in which 
the pit was dug is the lower unit of the arkoses and tuffaceous sandstones of Coal Creek. Choate (1962) indicates that the rock types present in the pit are arkosic sandstone overlain by a claystone containing thin seams of coal and carbonaceous materlal. The following is Choate's (1962, p. 67) description of the mineralization at the Coal Creek No. 4 pit:

Mineralization is known to occur in a zone roughly 120 feet long and 45 feet wide. The ore bed within the mineralized zone was sinuous in shape and trended roughly N-NW. Thickness of the ore bed ranged from 2 to 8 feet and averaged 5 feet. Width of the ore bed ranged from 15 to 30 feet. Most of the ore came from two pods within the ore bed.

Radioactivity measured at the Coal Creek No. 4 pit during the summer of 1977 ranged between 60 and 1,200 cps; the high value was measured in one very narrow zone near the southwest margin of the pit.

East Basin

The East Basin claims are located along East Basin Creek in secs. 17 and 18, T. $11 \mathrm{~N} .$, R. 14 E. Development was concentrated on an open pit on the East Basin No. 1 claim. The East Basin No. 1 pit is located approximately 2 miles upstream from the mouth of East Basin Creek, and is about 300 feet west of and 120 feet above the creek.

The rocks exposed in the pit in the summer of 1977 included mudstone, siltstone, poorly consolidated coal, and arkosic sandstone. Choate (1962) indicates that the ore was concentrated in a 3-foot-thick bed just above the contact with the batholith rocks. Choate's description of the ore bed (1962, p. 68-9) makes it clear that the ore bed was not exposed in the summer of 1977.

Rocks exposed in the walls of the pit gave scintillometer readings between 70 and $170 \mathrm{cps}$. Two small stockpiles of ore were present in the 
pit during the summer of 1977; they gave scintillometer readings of between 1,000 and 2,000 cps. The rocks present in the stockpiles are medium- to coarse-grained sandstones with yellow secondary uranium minerals present in many of the specimens. Considering the amount of mineral1zation present in the stockpiled ore, it would appear that further work on this property may be fustified.

Shorty

The Shorty pit is located in the NE $1 / 4 \mathrm{sec} .7$ and the NW $1 / 4 \mathrm{sec} .8$, T. $11 \mathrm{~N} .$, R. $14 \mathrm{E}$. The pit is in the lower unit of the arkoses and tuffaceous sandstones of Coal Creek; these rocks have been down-faulted relative to the andesite of Bonanza Peak that is exposed on the north side of the fault. The rocks in the pit were very poorly exposed in the summer of 1977; Choate (1962) describes the rocks as "interbedded coal, carboniferous mudstone, and arkosic sandstone. Most sedimentary rocks in the pit have been badly faulted, deformed, and drag folded." Choate further stated that the ore-grade mineralization was generally restricted to carbon-rich beds. Scintillometer readings from the pit gave values of up to $1,500 \mathrm{cps}$; rocks of ore grade are still present in the Shorty pit. Uranus

The Uranus claims are in the $\mathrm{SE} 1 / 4 \mathrm{sec} .8$, T. 11 N., R. 14 E., on the east side of East Basin Creek across from the East Basin No. 1 pit. Development consists of three bulldozer cuts on the north side of a dry creek bed that leads into East Basin Creek. The rocks were poorly exposed, but consisted of arkosic sandstones associated with mudstones; the rocks are from the lower unit of the arkoses and tuffaceous sandstones of Coal Creek. Sctntillometer readings in the cuts were between 250 and 310 cps. 
Choate (1962) states that although uranium is present on the Uranus claims, exploration has been too limited to indicate the extent and degree of mineralization.

Lucky Strike

The Lucky Strike claims are located in the NE 1/4, sec. 17, T. $11 \mathrm{~N}$. , R. 14 E., near the head of Tick Creek. The arkosic unit of the arkoses and tuffaceous sandstones of Coal Creek is exposed in a bulldozer cut. Rocks in the cut strike N. $75^{\circ} \mathrm{W}$, and dip $29^{\circ} \mathrm{N}$. The rocks give scintillometer readings between 300 and $500 \mathrm{cps}$. Choate (1962) states no mining was attempted on the property because: 1) the mineralized beds are thin, 2) the mineralization is relatively low grade, and 3) the beds dip steeply into the hill and would make open-pit mining difficult. 


\section{CONCLUSIONS}

1. The areas that are favorable for concealed uranium deposits beneath the Challis Volcanics in the Basin Creek-Yankee Fork district are those areas that are underlain in sub-surface by the lower unit of the arkoses and tuffaceous sandstones of Coal Creek.

2. It is unlikely that, in the Basin Creek-Yankee Fork district, units of the Challis Volcanics, other than the lower Coal Creek unit, will contain economic concentrations of uranium.

3. It is possible that the exposed uraniferous veins are present in the porphyritic and equigranular phases of the quartz monzonite of the Idaho batholith only where those phases were once unconformably overlain by the lower Coal Creek unit and where the latter has been removed by erosion.

4. Economic deposits of uranium may occur in the quartz monzonite phases where uraniferous veinlets, joint coatings, or disseminations are spaced sufficiently that low-grade ore is present. The east and southeast flanks of Potato Mountain and the valley sides of Upper Hardin Creek at the Hardee and Alta blocks of claims (see Choate, 1962, fig. 30) are possible locations for these kinds of deposits. It is unlikely that such deposits would extend to depth, but there is a potential for shallow, low-grade deposits of moderate tonnage; perhaps as much as 60,000 tons.

5. Uranium deposits simflar in size and grade to the above may exist subsurface in the quartz monzonite that is presently overlain by the lower 
Coal Creek unit and by younger Challis units. These concealed deposits would not constitute attractive drilling targets by themselves because of probable tonnage and grade limitations but may be attractive if bedded deposits are present in the superjacent lower unit.

6. Small, lenticular bedded uranium deposits are present in the lower unit of the arkoses and tuffaceous sandstones of Coal Creek which is exposed in the drainage basins of Basin Creek and Lower Hardin Creek. No bedded uranium deposits of economic size and grade remain unmined at the surface and, consequently, prospecting activity must be directed towards deposits, larger than those mined, that are buried beneath units of the Challis Volcanics.

7. A block of Challis Volcanics that lies north of the Little Joe, Elk, and Deer Strike claims (see Choate, 1962, fig. 8) in the $\mathrm{N} 1 / 2$ sec. 16 and $\mathrm{S} 1 / 2$, sec. 9, T. 11 N., R. 14 E. (see pl. 1 and section $\mathrm{B}-\mathrm{D}^{\prime}$ on $\mathrm{p} 1.2$ ) has a relatively thin cover, from 200 to 900 feet, of the upper Coal Creek unit and is an attractive drilling target for bedded deposits in the lower unit.

8. A Challis Volcanics block that is north of the Coal Creek claims in NW 1/4, sec. 16, T. 11 N., R. 14 E. has an upper Coal Creek cover from 200 to 600 feet and is a possible drilling target.

9. Another interesting prospecting target is the volcanic block that lies north, east, and west of the East Basin claims on East Basin Creek in 
sec. 8, T. $11 \mathrm{~N} .$, R. 14 E. Unfortunately, there $1 \mathrm{~s}$ an unknown amount of displacement down to the north on the fault that terminates the exposure of the lower Coal Creek unit on the northern side (see p1.1). If the displacement is not large, then a considerable area along the lower flanks of the East Basin Creek valley is of interest. The valley sides rise steep1y on the west and east and there is at least 800 feet and as much as 1,400 feet of andesite of Bonanza Peak overlying the lower unit (see p1. 2, section $\left.B-B^{\prime}\right)$. The subsurface extensions of the lower unit below the valley sides could be partially probed by angled holes drilled in a fan pattern from the lower slopes near the valley floor.

Potential, mining, and environmental problems will exist if ore is found in this block because the lower unit will be below East Basin Creek, which is a perennial stream with a moderately high discharge.

10. Other drilling targets are in the areas on the east and west sides of Short Creek that are partly covered by the Shorty claims in sec. 6, T. 11 N., R. 14 E. The lower and upper units of Coal Creek are not exposed because of overstepping by the andesite of Bonanza Peak (see p1. 1). The andesite is up to 600 feet thick on the ridge to the east. A N. $28^{\circ}$ W.trending fault displaces the lower unit about 200 feet down to the northeast between Hay Creek and Short Creek.

11. North of Hay Creek and south of Duffey Creek only two small areas are underlain by the lower unit (see p1.1). In each case, the upper unit of Coal Creek is missing and the andesite of Bonanza Peak lies directly upon the lower unit. This overlying cover of andesite lavas thickens 
abruptly in the down-dip direction to the northeast. The arkosic beds at the outcrop are only weakly radioactive and their extent down-dip and subsurface is problematical.

12. Float of arkosic pebble conglomerate of the lower Coal Creek unit occurs about one mile north-northeast of the confluence of Duffey and Basin creeks. The float is discontinuous over a strike length of about 2,500 feet and appears to have weathered from a bed no more than ten feet thick that ends to the east and the west on small faults. The total-count radioactivity is low and a single grab-sample (MAS 649) gave $22 \mathrm{ppm} \mathrm{U}_{3} 0_{8}$. Although there are considerable strike and down-dip dimensions of the arkose bed, the low uranium content and the restricted thickness of the bed, together with the rapidly increasing thickness of the overlying andesites down-dip, combine to make a poor prospecting target.

13. The northern most outcrop of the lower unit of Coal Creek in the study area occurs 500 feet west of peak 8449 (p1. 1). The unit is very thin and a grab-sample of arkosic conglomerate bed gave only $2 \mathrm{ppm} \mathrm{U}_{3} \mathrm{O}_{8}$ (MAS 650). To the north of this locality and west of Red Mountain the horizon of the Coal Creek unit is concealed because of faulting and there is no certainty that the lower unit was deposited (p1. 2, section $\left.\mathrm{D}-\mathrm{D}^{\prime}\right)$

14. The problems of subsurface prospecting in the study area are intensified with increasing distance from the outcrops of the lower Coal Creek unit. We do not know if the lower unit was deposited and exists subsur- 
face beneath the main body of Challis Volcanics in the upper reaches of East Basin Creek, Hay Creek and Duffey Creek, and in the West Fork drainage (see p1. 1 and 2). Also, we have little Information in these areas about the total thickness of the Challis units and the depth to the contact with the quartz monzonite. The areas of our uncertainty and our best estimates of thicknesses are indicated on the four sections of Plate 2.

15. It is unlikely that bedded uranium deposits exist close to the surface along the faulted contact between the andesite of Bonanza Peak and the quartz monzonite on Sawmill Creek and the area south of East Basin Lake.

16. The intrusions of the rhyolites of West Fork and McGowan Peak do not cause appreciable doming of the Challis beds at the surface and it is improbable that the lower Coal Creek unit, even if present, has been domed into positions nearer the surface.

17. The West Fork drainage has not downcut sufficiently to expose the base of the Challis Volcanics. There are indications that at least several hundred feet of volcanic beds exist below the lowest level on West Fork (see p1. 2, sections $C-C^{\prime}$ and $D^{-} D^{\prime}$ ). At present, on the evidence available, the West Fork drainage basin is unattractive for subsurface exploration.

18. It will be difficult by most prospecting techniques to confirm the presence of and the depth to bedded uranium deposits in the lower Coal Creek unit beneath the cover of Challis Volcanics between Stanley Basin 
and the West Fork. It is possible that radon or helium geochemical surveys might be of value in detecting secondary dispersion patterns from concealed deposits. Deep, wild-cat drilling might be the only technique to discover new orebodies in most of the area. 
We wish to acknowledge the geological contributions expressed through written communtcations and conversations over the past 6 years by earlier students of the Challis volcanic fleld: Hillton Cass, Christopher Broili, Elliot Crist, and Bipinkumar Bhatt. Our knowledge on the Challis Volcanics of the Yankee Fork and Challis region has been helped by conversations with David McIntyre of the U. S. Geological Survey. Donald A. Seeland of the U. S. Geological Survey helped us with his knowledge on the Paleozoic sedimentary beds of central Idaho.

George A. Williams, University of Idaho, generously allowed us the use of two Honda trailbikes for the field season.

Peter Hooper, Washington State University, provided access to, and assistance with, a XRF spectrometer. 


\section{REFERENCES}

Anderson, A.L., 1949, The silver-gold deposits of the Yankee Fork district. Custer County, Idaho: Idaho Bur. Mines and Geology Pamph. 83, 37p.

Armstrong, R.L., 1975, Geochronometry of Idaho: Ischron/West, no. 14, p. $1-50$.

Armstrong, R.L., Taubeneck, W.H., and Hales, P.0., 1977, Rb-Sr and $\mathrm{K}-\mathrm{Ar}$ Geochronometry of Mesozolc granitic rocks and their Sr isotopic composition, Oregon, Washington, and Nevada: Geol. Soc. America Bull. v. 88, p. 397-411.

Balk, Robert, 1937, Structural behavior of Igneous rocks: Geol. Soc. America Memoir 5, 177p.

Bhatt, B.J., 1978, Geology and hydrothermal alteration of the West Fork Yankee Fork, Custer County, Idaho: Unpub. M.S. Thesis, Univ. of Idaho, $107 \mathrm{p}$.

Bowen, R.W., 1971, Graphic Normative Analysis Program, Program C542, U. S. Geol. Survey Computer Program Documentation (unpub.).

Broili, C.J., 1974, Geology and alteration of the southeastern part of Yankee Fork mining district, Custer County, Idaho: Unpub. M.S. Thesis, Univ. of Idaho, $114 \mathrm{p}$.

Carmichael, I.S.E., Turner, F.J., and Verhoogen, John, 1974, Igneous petrology: New York, McGraw-Hi11, Inc., 739p.

Cass, H.K., 1973, geology and alteration of the Jordan Creek area, Yankee Fork mining district, Custer County, Idaho: Unpub. M.S. Thesis, Univ. of Idaho, 92p.

Choate, Raoul, 1962, Geology and ore deposits of the Stanley area: Idaho Bur. Mines and Geology Pamph. 126, 122p.

Crist, E.M., 1978, Geology of the upper Lightning Creek and upper Jordan Creek area, Custer County, Idaho: Unpub. M.S. Thesis, Univ. of Idaho, 91p.

Culbert, R.R., and Leighton, D.G., 1978, Uranium in alkaline waters-0kanagan area, British Columbia: Can. Inst. Mining Metallurgy Bu11., May, p. 103-110.

Fisher, R.V., 1960, Classification of volcanic breccias: Geol Soc. America Bul1., v. 71, p. 973-982.

1966, Rocks composed of volcanic fragments and their classification: Earth-Sci. Rev., v. 1, no. 4, p. 287-289. 
Ha11, W.E., Batchelder, John, and Douglas, R.C., 1974, Stratigraphic section of the Wood River Formation, Blaine County, Idaho: U. S. Geo1. Survey Journ. Research, v. 2, p. 89-95.

Hyndman, D.W., Badley, Ruth, and Reba1, Donald, 1977, Northeast-trending early Tertiary dike swarm in central Idaho and western Montana (abs): Abstracts with Programs Geo1. Soc. America, v. 9, no. 6, p. 734.

Irvine, T.N., and Baragar, W.R.A., 1971, A guide to the chemical classIfication of the common volcanic rocks: Canadian Journ. Earth Sciences v. 8 , p. 523-548.

Jackson, K.C., 1970, Testbook of 1ithology: San Francisco, McGraw-Hill, $552 \mathrm{p}$.

Jakes, P., and White, A.J.R., 1972, Major and trace element abundances in volcanic rocks of orogenic areas: Geol. Soc. America Bull., v. 83, p. $29-40$.

Kern, B.F., 1959, Geology of the uranium deposits near Stanley, Custer County, Idaho: Idaho Bur. Mines and Geology Pamph. 117, 40p.

Kerr, P.F., 1959, Optical mineralogy: New York, McGraw-Hill Book Company, 442p.

Kiilsgaard, T.H., Freeman, V.L., and Coffman, J.S., 1970, Mineral resources of the Sawtooth Primitive Area, Idaho: U. S. Geol. Survey Bull. 1319-D, 174p.

Levinson, A.A., 1974, Introduction to exploration geochemistry: Applied Publishing Ltd., Wilmette, I11., 614p.

Lipman, P.W., 1975, Evolution of the Platero Caldera complex and related volcanic rocks, southeastern San Juan mountalns, Colorado: U. S. Geo1. Survey Prof. Paper 852, 128p.

Lipman, P.W., Prostka, H.J., and Christiansen, R.L., 1971, Evolving subduction zones in the western United States, as interpreted from igneous rocks: Science, v. 174, p. 821-825.

1972, Cenozoic volcanism and plate-tectonic evolution of the western United States. I. Early and middle Cenozoic: Phil. Trans. R. Soc. Lond. A., v. 271, p. 217-248.

Nockolds, S.R., and Allen, R., 1953, The geochemistry of some igneous rock series: Geochemical et. Cosmochimica Acta, v. 4, p. 105-142.

Peterson, D.W., 1961, A.G.I. data sheet 23, Descriptive classification of igneous rocks: Geotimes. v. 5, no. 6, p. 30-36.

Pettijohn, F.J., Potter, P.E., and Siever, Raymond, 1972, Sand and sandstone: New York, Springer-Verlag, 618p. 
Ross, C.P., 1927, Ore deposits in Tertiary lava in the Salmon River Mountains, Idaho: Idaho Bur. Mines and Geology Pamph. 25, 21p.

1934, Geology and ore deposits of the Casto quadrangle Idaho: U. S. Geol. Survey Bul1. 854, 135p.

1937, Geology and ore deposits of the Bayhorse quadrangle, Custer County, Idaho: U.S. Geo1. Survey Bu11. 877, 161p.

1961, A redefintion and restriction of the term Challis Volcanics: U. S. Geol. Survey Prof. Paper 424.

1962, Stratified rocks in south-central Idaho: Idaho Bur. Mines and Geology Pamph. 125. 126p.

Siems, P.L., and Jones, R.W., 1977, The Challis volcanic field: a review (abs): Abstracts with programs, Geol Soc. America, v. 9, no. 6, p. 762-763.

Stiles, L.A., 1976, Geology and alteration of the West Fork of Mayfield Creek area, Custer County, Idaho: Unpub. M.S. Thesis, Univ. of Idaho, 136p.

Tarling, D.H., and Mitchell, J.G., 1976, Revised Cenozoic polarity time scale: Geology, v. 4, no. 3, p. 133-136.

Taylor, S.R., Capp, Annette C., Graham, A.L., and Blake, D.H., 1969, Trace element abundances in andesites II Saipan, Bougainville and Fiji: Contrib. Mineral. and Petrol., v. 23, p. 1-26.

Tschanz, C.M., Kiilsgaard, T.H., and others, 1974, Mineral resources of the eastern part of the Sawtooth National Recreation Area, Custer and Blalne Counties, Idaho: U. S. Geo1. Survey Open-file Rep.

Umpleby, J.B., 1913, Some ore deposits in northwestern Custer County, Idaho: U. S. Geol. Survey Bu11. 539, $104 \mathrm{p}$.

Umpleby, J.B., Westgate, L.G., and Ross, C.P., 1930, Geology and ore deposits of the Wood River region, Idaho: U. S. Geol. Survey Bull. $814,250 p$.

Williams, P.L., 1960, A stained slice method for rapid determination of phenocryst composition of volcanic rocks: Amer. Journ. Sci., v. 258 , p. $148-152$.

1961, Glacial geology of Stanley Basin: Idaho Bur. Mines Geology Pamph. 123, 29p.

Zielinsk1, R.A., Lipman, P.W., and Millard, H.T. JR., 1977, Minorelement abundances in obsidian, perlite, and felsite of cakalkalic rhyolite: American Mineralogist, v. 62, p. 426-437. 

APPENDIX

Table 1. Major oxide analyses. 
GEOCHEMISTRY OF INTRUSIVE AND EXIRUSIVE ROCKS IN THE CHALLIS VOLCANICS

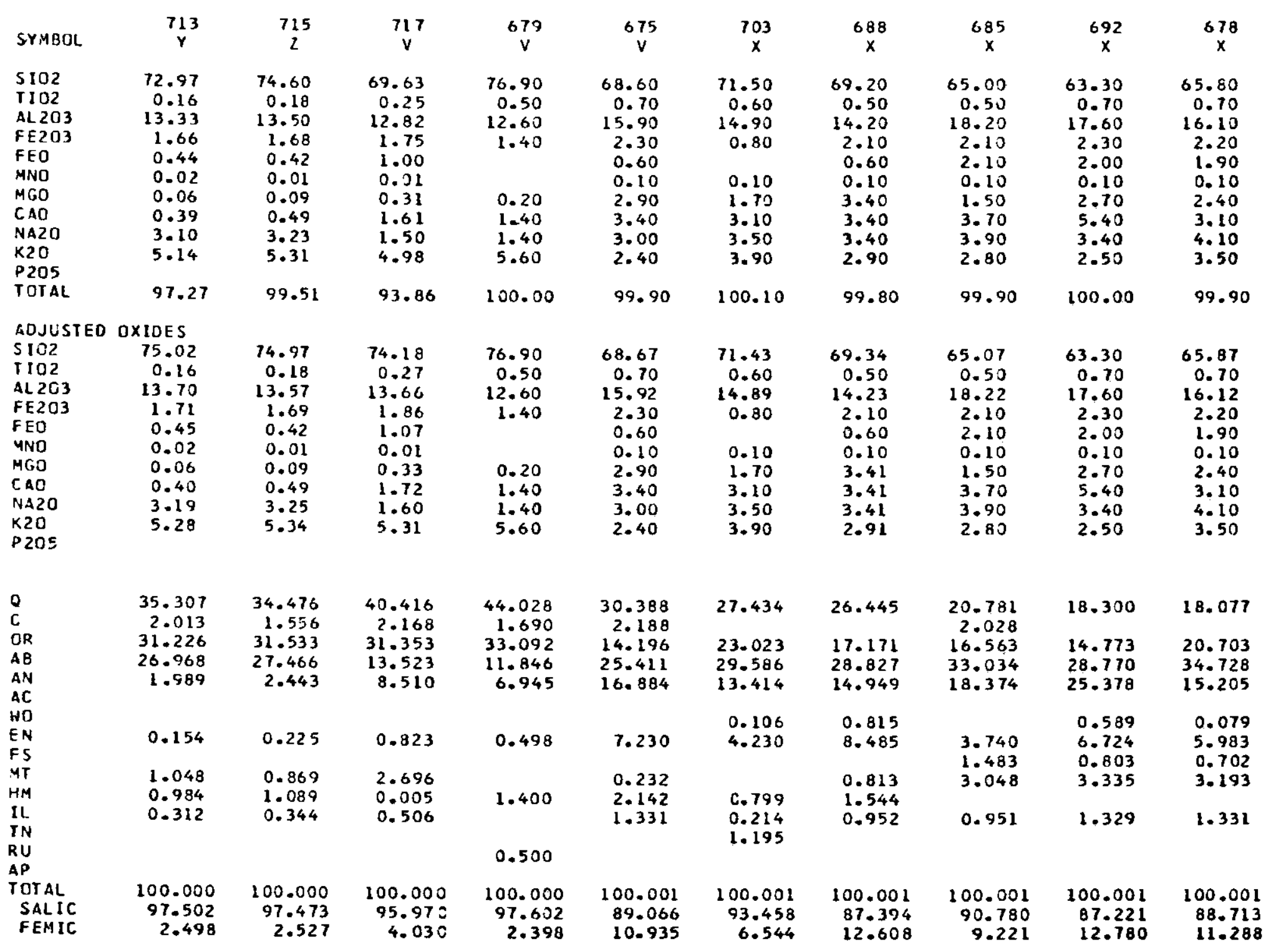


GEOCHEMISTRY OF INTRUSIVE ANO EXTRUSIVE ROCKS IN THE CHALLIS VOLCANICS

\begin{tabular}{|c|c|c|c|c|c|c|c|c|c|c|c|c|}
\hline SYMBOL & $\begin{array}{c}639 \\
Z\end{array}$ & $\begin{array}{c}640 \\
Z\end{array}$ & $\begin{array}{c}643 \\
2\end{array}$ & $\begin{array}{c}646 \\
Y\end{array}$ & $\begin{array}{c}661 \\
Y\end{array}$ & $\begin{array}{c}664 \\
x\end{array}$ & $\begin{array}{c}666 \\
x\end{array}$ & 711 & $\begin{array}{c}714 \\
x\end{array}$ & $\begin{array}{c}722 \\
x\end{array}$ & $\begin{array}{c}727 \\
\times\end{array}$ & $\begin{array}{c}876 \\
x\end{array}$ \\
\hline $\begin{array}{l}S 102 \\
\text { T1O2 } \\
\text { AL2O3 } \\
\text { FE2O3 } \\
\text { FEO } \\
\text { MNO } \\
\text { MGO } \\
\text { CAO } \\
\text { NA2O } \\
\text { K2O } \\
\text { P2OS }\end{array}$ & $\begin{array}{r}81.76 \\
0.13 \\
10.78 \\
1.63 \\
0.42 \\
0.01 \\
0.02 \\
0.15 \\
3.32 \\
4.62\end{array}$ & $\begin{array}{r}82.28 \\
0.13 \\
10.94 \\
1.63 \\
0.42 \\
0.05 \\
0.02 \\
0.10 \\
3.27 \\
4.41\end{array}$ & $\begin{array}{r}80.05 \\
0.12 \\
11.62 \\
1.00 \\
\\
0.02 \\
0.01 \\
0.13 \\
3.94 \\
4.38\end{array}$ & $\begin{array}{r}78.13 \\
0.17 \\
11.79 \\
1.67 \\
0.43 \\
0.01 \\
0.02 \\
0.23 \\
3.76 \\
4.97\end{array}$ & $\begin{array}{r}75.15 \\
0.26 \\
13.16 \\
1.76 \\
0.99 \\
0.03 \\
0.22 \\
0.60 \\
3.27 \\
4.90\end{array}$ & $\begin{array}{r}58.59 \\
0.80 \\
14.36 \\
2.30 \\
2.20 \\
0.16 \\
2.69 \\
2.89 \\
3.10 \\
3.10\end{array}$ & $\begin{array}{r}60.20 \\
0.67 \\
15.72 \\
2.17 \\
3.64 \\
0.08 \\
2.99 \\
4.72 \\
3.63 \\
2.47\end{array}$ & $\begin{array}{r}55.58 \\
0.58 \\
16.24 \\
2.08 \\
0.70 \\
0.09 \\
2.45 \\
6.43 \\
3.41 \\
2.12\end{array}$ & $\begin{array}{r}54.01 \\
0.94 \\
15.89 \\
2.44 \\
6.81 \\
0.10 \\
3.47 \\
6.11 \\
3.01 \\
2.82\end{array}$ & $\begin{array}{r}55.90 \\
0.89 \\
15.89 \\
2.39 \\
4.28 \\
0.11 \\
3.23 \\
6.55 \\
2.74 \\
2.82\end{array}$ & $\begin{array}{r}54.83 \\
0.88 \\
16.07 \\
2.38 \\
4.29 \\
0.13 \\
4.26 \\
7.06 \\
2.96 \\
2.51\end{array}$ & $\begin{array}{r}75.71 \\
0.67 \\
12.65 \\
2.17 \\
1.91 \\
0.08 \\
1.67 \\
3.54 \\
3.81 \\
2.73\end{array}$ \\
\hline TOTAL & 102.84 & 103.25 & 101.27 & 101.18 & 100.34 & 90.19 & 96.29 & 89.68 & 95.60 & 94.80 & 95.37 & 105.00 \\
\hline $\begin{array}{l}\text { ADJUSTED } \\
\text { SIO2 } \\
\text { TIO2 } \\
\text { AL } 203 \\
\text { FE2O3 } \\
\text { FEO } \\
\text { MNO } \\
\text { MGO } \\
\text { CAO } \\
\text { NA2O } \\
\text { K2O } \\
\text { P2OS }\end{array}$ & $\begin{array}{c}\text { DXIDES } \\
79.50 \\
0.13 \\
10.48 \\
1.58 \\
0.41 \\
0.01 \\
0.02 \\
0.15 \\
3.23 \\
4.49\end{array}$ & $\begin{array}{r}79.69 \\
0.13 \\
10.60 \\
1.58 \\
0.41 \\
0.05 \\
0.02 \\
0.10 \\
3.17 \\
4.27\end{array}$ & $\begin{array}{r}79.05 \\
0.12 \\
11.47 \\
0.99 \\
0.02 \\
0.01 \\
0.13 \\
3.89 \\
4.33\end{array}$ & $\begin{array}{r}77.22 \\
0.17 \\
11.65 \\
1.65 \\
0.42 \\
0.01 \\
0.02 \\
0.23 \\
3.72 \\
4.91\end{array}$ & $\begin{array}{r}74.90 \\
0.26 \\
13.12 \\
1.75 \\
0.99 \\
0.03 \\
0.22 \\
0.60 \\
3.26 \\
4.88\end{array}$ & $\begin{array}{r}64.96 \\
0.89 \\
15.92 \\
2.55 \\
2.44 \\
0.18 \\
2.98 \\
3.20 \\
3.44 \\
3.44\end{array}$ & $\begin{array}{r}62.52 \\
0.70 \\
16.33 \\
2.25 \\
3.78 \\
0.08 \\
3.11 \\
4.90 \\
3.77 \\
2.57\end{array}$ & $\begin{array}{r}61.98 \\
0.65 \\
18.11 \\
2.32 \\
0.78 \\
0.10 \\
2.73 \\
7.17 \\
3.80 \\
2.36\end{array}$ & $\begin{array}{r}56.50 \\
0.98 \\
16.62 \\
2.55 \\
7.12 \\
0.10 \\
3.63 \\
6.39 \\
3.15 \\
2.95\end{array}$ & $\begin{array}{r}58.97 \\
0.94 \\
16.76 \\
2.52 \\
4.51 \\
0.12 \\
3.41 \\
6.91 \\
2.89 \\
2.97\end{array}$ & $\begin{array}{r}57.49 \\
0.92 \\
16.85 \\
2.50 \\
4.50 \\
0.14 \\
4.47 \\
7.40 \\
3.10 \\
2.63\end{array}$ & $\begin{array}{r}72.10 \\
0.64 \\
12.05 \\
2.07 \\
1.82 \\
0.08 \\
1.59 \\
3.37 \\
3.63 \\
2.66\end{array}$ \\
\hline $\begin{array}{l}0 \\
C \\
O R \\
A B \\
A N \\
A C\end{array}$ & $\begin{array}{r}43.191 \\
0.044 \\
26.547 \\
27.317 \\
0.724\end{array}$ & $\begin{array}{r}44.686 \\
0.586 \\
25.240 \\
26.799 \\
0.480\end{array}$ & $\begin{array}{r}39.574 \\
0.159 \\
25.558 \\
32.921 \\
0.637\end{array}$ & $\begin{array}{r}36.401 \\
29.027 \\
31.445 \\
0.607\end{array}$ & $\begin{array}{r}35.643 \\
1.381 \\
28.857 \\
27.576 \\
2.967\end{array}$ & $\begin{array}{r}19.940 \\
0.721 \\
20.311 \\
29.085 \\
15.897\end{array}$ & $\begin{array}{l}14.704 \\
15.158 \\
31.899 \\
20.048\end{array}$ & $\begin{array}{l}13.581 \\
13.969 \\
32.175 \\
25.362\end{array}$ & $\begin{array}{r}5.428 \\
17.431 \\
26.642 \\
22.508\end{array}$ & $\begin{array}{l}10.892 \\
17.578 \\
24.457 \\
23.976\end{array}$ & $\begin{array}{l}7.291 \\
15.552 \\
26.263 \\
24.273\end{array}$ & $\begin{array}{r}32.632 \\
15.702 \\
30.704 \\
8.738\end{array}$ \\
\hline $\begin{array}{l}\text { WO } \\
\text { EN } \\
\text { FS } \\
\text { MT }\end{array}$ & $\begin{array}{l}0.048 \\
0.982\end{array}$ & $\begin{array}{l}0.048 \\
1.104\end{array}$ & 0.025 & $\begin{array}{l}0.217 \\
0.049 \\
0.915\end{array}$ & $\begin{array}{l}0.546 \\
2.526\end{array}$ & $\begin{array}{l}7.428 \\
1.238 \\
3.698\end{array}$ & $\begin{array}{l}1.783 \\
7.734 \\
4.085 \\
3.268\end{array}$ & $\begin{array}{l}4.262 \\
6.804 \\
0.969\end{array}$ & $\begin{array}{l}3.841 \\
9.040 \\
9.543 \\
3.701\end{array}$ & $\begin{array}{l}4.301 \\
8.486 \\
4.873 \\
3.655\end{array}$ & $\begin{array}{r}5.199 \\
11.125 \\
4.928 \\
3.618\end{array}$ & $\begin{array}{l}3.335 \\
3.961 \\
0.721 \\
2.996\end{array}$ \\
\hline $\begin{array}{l}\text { HM } \\
\text { IL } \\
\text { TN }\end{array}$ & $\begin{array}{l}0.908 \\
0.240\end{array}$ & $\begin{array}{l}0.817 \\
0.239\end{array}$ & $\begin{array}{l}0.987 \\
0.042\end{array}$ & $\begin{array}{l}1.019 \\
0.319\end{array}$ & $\begin{array}{l}0.012 \\
0.492\end{array}$ & 1.685 & 1.321 & $\begin{array}{l}1.651 \\
1.228\end{array}$ & 1.867 & 1.783 & 1.752 & 1.212 \\
\hline RU & & & 0.096 & & & & & & & & & \\
\hline $\begin{array}{l}\text { TOTAL } \\
\text { SALIC } \\
\text { FEMIC }\end{array}$ & $\begin{array}{r}100.000 \\
97.822 \\
2.178\end{array}$ & $\begin{array}{r}100.001 \\
97.792 \\
2.209\end{array}$ & $\begin{array}{r}100.000 \\
98.850 \\
1.151\end{array}$ & $\begin{array}{r}100.000 \\
97.480 \\
2.520\end{array}$ & $\begin{array}{r}100.000 \\
96.424 \\
3.576\end{array}$ & $\begin{array}{r}100.002 \\
85.954 \\
14.048\end{array}$ & $\begin{array}{r}100.001 \\
81.810 \\
18.191\end{array}$ & $\begin{array}{r}100.001 \\
85.087 \\
14.915\end{array}$ & $\begin{array}{r}100.001 \\
72.009 \\
27.992\end{array}$ & $\begin{array}{r}100.001 \\
76.903 \\
23.098\end{array}$ & $\begin{array}{r}100.002 \\
73.378 \\
26.623\end{array}$ & $\begin{array}{r}100.001 \\
87.775 \\
12.226\end{array}$ \\
\hline
\end{tabular}


GEOCHEMISTRY OF INTRUSIVE AND EXIPUSIVE ROCKS IN THE CHALLIS VOLCANICS

\begin{tabular}{|c|c|c|c|c|c|c|c|c|c|c|c|c|}
\hline SYMBOL & $\begin{array}{c}A-090 \\
W\end{array}$ & $\begin{array}{c}A-081 \\
x\end{array}$ & $\begin{array}{c}A-080 \\
x\end{array}$ & $\begin{array}{c}A=079 \\
x\end{array}$ & $\begin{array}{c}A-076 \\
x\end{array}$ & $\begin{array}{c}A-073 \\
x\end{array}$ & $\begin{array}{c}A-070 \\
X\end{array}$ & $\begin{array}{c}A-068 \\
x\end{array}$ & $\begin{array}{c}A-067 \\
x\end{array}$ & $\begin{array}{c}A-057 \\
x\end{array}$ & $\frac{4-011}{x}$ & $\begin{array}{c}635 \\
2\end{array}$ \\
\hline $\begin{array}{l}\text { SIO2 } \\
\text { T102 } \\
\text { AL2O3 } \\
\text { FE203 } \\
\text { FEO } \\
\text { MNO } \\
\text { MGO } \\
\text { CAO } \\
\text { NA2O } \\
\text { K2O } \\
\text { P2O5 } \\
\text { TOTAL }\end{array}$ & $\begin{array}{c}54.72 \\
1.64 \\
16.49 \\
3.14 \\
5.59 \\
0.14 \\
4.57 \\
7.54 \\
3.46 \\
2.13 \\
0.52 \\
99.94\end{array}$ & $\begin{array}{c}68.82 \\
0.74 \\
16.56 \\
2.24 \\
3.01 \\
0.02 \\
0.65 \\
2.57 \\
3.49 \\
2.89 \\
0.21 \\
101.20\end{array}$ & $\begin{array}{r}66.61 \\
0.64 \\
15.30 \\
2.14 \\
2.71 \\
0.06 \\
1.17 \\
3.24 \\
3.49 \\
2.49 \\
0.39 \\
98.24\end{array}$ & $\begin{array}{r}64.49 \\
0.96 \\
16.70 \\
2.46 \\
2.03 \\
0.11 \\
1.94 \\
4.98 \\
3.51 \\
3.21 \\
0.42 \\
100.81\end{array}$ & $\begin{array}{r}68.77 \\
0.05 \\
15.26 \\
1.08 \\
3.55 \\
0.04 \\
2.59 \\
3.92 \\
3.58 \\
3.43 \\
0.28 \\
102.55\end{array}$ & $\begin{array}{r}71.28 \\
0.70 \\
13.67 \\
2.20 \\
0.54 \\
0.09 \\
1.67 \\
5.30 \\
3.54 \\
5.19 \\
0.52 \\
104.70\end{array}$ & $\begin{array}{r}63.57 \\
0.90 \\
17.52 \\
2.40 \\
3.72 \\
0.09 \\
2.82 \\
5.65 \\
3.49 \\
3.10 \\
0.27 \\
103.53\end{array}$ & $\begin{array}{r}73.48 \\
0.68 \\
12.85 \\
2.18 \\
3.69 \\
0.07 \\
0.91 \\
3.27 \\
3.57 \\
3.99 \\
0.24 \\
104.93\end{array}$ & $\begin{array}{r}64.30 \\
1.20 \\
18.83 \\
2.70 \\
2.49 \\
0.04 \\
1.98 \\
3.82 \\
3.51 \\
4.60 \\
0.57 \\
104.04\end{array}$ & $\begin{array}{r}71.82 \\
0.55 \\
17.08 \\
2.05 \\
1.16 \\
0.04 \\
1.72 \\
2.51 \\
3.46 \\
3.11 \\
0.16 \\
103.66\end{array}$ & $\begin{array}{r}68.92 \\
0.45 \\
14.81 \\
1.95 \\
1.41 \\
0.08 \\
1.39 \\
2.34 \\
3.51 \\
4.19 \\
0.15 \\
99.20\end{array}$ & $\begin{array}{r}81.76 \\
0.18 \\
11.79 \\
1.69 \\
0.44 \\
0.02 \\
0.08 \\
0.31 \\
3.10 \\
4.83 \\
104.20\end{array}$ \\
\hline $\begin{array}{l}\text { ADJUSTED } \\
\text { SIO2 } \\
\text { IIO2 } \\
\text { AL } 203 \\
\text { FE2O3 } \\
\text { FEO } \\
\text { MNO } \\
\text { MGO } \\
\text { CAO } \\
\text { NA2O } \\
\text { K2O } \\
\text { P2OS }\end{array}$ & $\begin{array}{c}\text { OXIDES } \\
54.75 \\
1.64 \\
16.50 \\
3.14 \\
5.59 \\
0.14 \\
4.57 \\
7.54 \\
3.46 \\
2.13 \\
0.52\end{array}$ & $\begin{array}{r}68.00 \\
0.73 \\
16.36 \\
2.21 \\
2.97 \\
0.02 \\
0.64 \\
2.54 \\
3.45 \\
2.86 \\
0.21\end{array}$ & $\begin{array}{r}67.80 \\
0.65 \\
15.57 \\
2.18 \\
2.76 \\
0.06 \\
1.19 \\
3.30 \\
3.55 \\
2.53 \\
0.40\end{array}$ & $\begin{array}{r}63.97 \\
0.95 \\
16.57 \\
2.44 \\
2.01 \\
0.11 \\
1.92 \\
4.94 \\
3.48 \\
3.18 \\
0.42\end{array}$ & $\begin{array}{r}67.06 \\
0.05 \\
14.88 \\
1.05 \\
3.46 \\
0.04 \\
2.53 \\
3.82 \\
3.49 \\
3.34 \\
0.27\end{array}$ & $\begin{array}{r}68.08 \\
0.67 \\
13.06 \\
2.10 \\
0.52 \\
0.09 \\
1.60 \\
5.06 \\
3.38 \\
4.96 \\
0.50\end{array}$ & $\begin{array}{r}61.40 \\
0.87 \\
16.92 \\
2.32 \\
3.59 \\
0.09 \\
2.72 \\
5.46 \\
3.37 \\
2.99 \\
0.26\end{array}$ & $\begin{array}{r}70.03 \\
0.65 \\
12.25 \\
2.08 \\
3.52 \\
0.07 \\
0.87 \\
3.12 \\
3.40 \\
3.80 \\
0.23\end{array}$ & $\begin{array}{r}61.80 \\
1.15 \\
18.10 \\
2.60 \\
2.39 \\
0.04 \\
1.90 \\
3.67 \\
3.37 \\
4.42 \\
0.55\end{array}$ & $\begin{array}{r}69.28 \\
0.53 \\
16.48 \\
1.98 \\
1.12 \\
0.04 \\
1.66 \\
2.42 \\
3.34 \\
3.00 \\
0.15\end{array}$ & $\begin{array}{r}69.48 \\
0.45 \\
14.93 \\
1.97 \\
1.42 \\
0.08 \\
1.40 \\
2.36 \\
3.54 \\
4.22 \\
0.15\end{array}$ & $\begin{array}{r}78.46 \\
0.17 \\
11.31 \\
1.62 \\
0.42 \\
0.02 \\
0.08 \\
0.30 \\
2.98 \\
4.64\end{array}$ \\
\hline $\begin{array}{l}Q \\
C \\
Q R \\
A B \\
A N \\
A C\end{array}$ & $\begin{array}{r}4.906 \\
12.594 \\
29.295 \\
23.187\end{array}$ & $\begin{array}{r}30.081 \\
3.479 \\
16.875 \\
29.181 \\
11.243\end{array}$ & $\begin{array}{r}28.669 \\
1.941 \\
14.978 \\
30.060 \\
13.768\end{array}$ & $\begin{array}{l}19.462 \\
18.816 \\
29.462 \\
20.168\end{array}$ & $\begin{array}{l}20.733 \\
19.765 \\
29.540 \\
15.055\end{array}$ & $\begin{array}{r}21.089 \\
29.292 \\
28.610 \\
5.809\end{array}$ & $\begin{array}{l}14.449 \\
17.694 \\
28.525 \\
22.200\end{array}$ & $\begin{array}{r}28.1 .56 \\
22.470 \\
28.789 \\
6.913\end{array}$ & $\begin{array}{r}15.911 \\
2.399 \\
26.127 \\
28.547 \\
14.636\end{array}$ & $\begin{array}{r}31.161 \\
3.706 \\
17.729 \\
28.244 \\
11.004\end{array}$ & $\begin{array}{r}25.838 \\
0.610 \\
24.959 \\
29.940 \\
10.714\end{array}$ & $\begin{array}{r}42.669 \\
0.863 \\
27.391 \\
25.174 \\
1.476\end{array}$ \\
\hline $\begin{array}{l}\text { WO } \\
\text { EN } \\
\text { FS } \\
\text { MT } \\
\text { HM } \\
\text { IL } \\
\text { TN } \\
\text { RU }\end{array}$ & $\begin{array}{r}4.527 \\
11.388 \\
5.226 \\
4.555 \\
3.117\end{array}$ & $\begin{array}{l}1.600 \\
2.462 \\
3.209 \\
1.389\end{array}$ & $\begin{array}{l}2.966 \\
2.304 \\
3.158 \\
1.237\end{array}$ & $\begin{array}{r}0.675 \\
4.793 \\
0.312 \\
3.538 \\
1.809\end{array}$ & $\begin{array}{l}0.887 \\
6.290 \\
5.479 \\
1.527 \\
0.093\end{array}$ & $\begin{array}{l}6.705 \\
3.972 \\
\\
0.005 \\
2.098 \\
1.270\end{array}$ & $\begin{array}{l}1.324 \\
6.784 \\
3.409 \\
3.361 \\
1.651\end{array}$ & $\begin{array}{r}2.945 \\
2.160 \\
3.795 \\
3.012 \\
1.231\end{array}$ & $\begin{array}{l}4.740 \\
0.418 \\
3.763 \\
2.191\end{array}$ & $\begin{array}{l}4.132 \\
2.195 \\
0.464 \\
1.008\end{array}$ & $\begin{array}{l}3.490 \\
0.387 \\
2.850 \\
0.862\end{array}$ & $\begin{array}{l}0.191 \\
0.923 \\
0.985 \\
0.328\end{array}$ \\
\hline $\begin{array}{l}\text { AP } \\
\text { TOTAL } \\
\text { SAL IC } \\
\text { FEMIC }\end{array}$ & $\begin{array}{r}1.232 \\
100.029 \\
69.982 \\
30.046\end{array}$ & $\begin{array}{r}0.492 \\
100.011 \\
90.859 \\
9.152\end{array}$ & $\begin{array}{r}0.940 \\
100.021 \\
89.415 \\
10.606\end{array}$ & $\begin{array}{r}0.987 \\
100.023 \\
87.909 \\
12.114\end{array}$ & $\begin{array}{c}0.647 \\
100.015 \\
85.092 \\
14.922\end{array}$ & $\begin{array}{c}1.176 \\
100.027 \\
84.800 \\
15.227\end{array}$ & $\begin{array}{c}0.618 \\
100.014 \\
82.868 \\
17.146\end{array}$ & $\begin{array}{c}0.542 \\
100.013 \\
86.328 \\
13.685\end{array}$ & $\begin{array}{c}1.298 \\
100.029 \\
87.620 \\
12.408\end{array}$ & $\begin{array}{r}0.366 \\
100.008 \\
91.844 \\
8.164\end{array}$ & $\begin{array}{r}0.358 \\
100.009 \\
92.062 \\
7.946\end{array}$ & $\begin{array}{r}100.000 \\
97.573 \\
2.428\end{array}$ \\
\hline
\end{tabular}


GECCHEMISTRY OF INTRUSIVE ANO EXTRUSIVE ROCKS IN THE CHALLIS VOLCANICS

\begin{tabular}{|c|c|c|c|c|c|c|c|c|c|c|c|c|}
\hline SYMBOL & $\begin{array}{c}A-119 \\
Z\end{array}$ & $\begin{array}{c}A-145 \\
Z\end{array}$ & $\begin{array}{c}A-160 \\
Z\end{array}$ & $\begin{array}{c}A-223 \\
V\end{array}$ & $A-2 \underset{V}{222}$ & $\begin{array}{c}A-165 \\
W\end{array}$ & $\begin{array}{c}A-135 \\
Z\end{array}$ & $\begin{array}{c}A-121 \\
W\end{array}$ & $\begin{array}{c}A-106 \\
W\end{array}$ & $\begin{array}{c}A-101 \\
W\end{array}$ & $\begin{array}{c}A-100^{\circ} \\
W\end{array}$ & $\begin{array}{c}A-096 \\
W\end{array}$ \\
\hline $\begin{array}{l}\text { SIO2 } \\
\text { T102 } \\
\text { AL2O3 } \\
\text { FE2O3 } \\
\text { FEO } \\
\text { MNO } \\
\text { MGO } \\
\text { CAO } \\
\text { NA2O } \\
\text { K2O } \\
\text { P2O5 } \\
\text { TOTAL }\end{array}$ & $\begin{array}{r}83.21 \\
0.10 \\
10.89 \\
1.65 \\
0.53 \\
0.03 \\
0.15 \\
0.11 \\
3.63 \\
4.87 \\
0.04 \\
105.21\end{array}$ & $\begin{array}{r}80.05 \\
0.04 \\
10.81 \\
0.98 \\
\\
0.02 \\
0.05 \\
0.07 \\
3.56 \\
4.01 \\
0.02 \\
99.61\end{array}$ & $\begin{array}{r}79.25 \\
0.11 \\
13.92 \\
0.39 \\
\\
0.01 \\
0.31 \\
2.55 \\
3.66 \\
4.08 \\
0.04 \\
104.32\end{array}$ & $\begin{array}{c}69.18 \\
0.48 \\
15.70 \\
1.98 \\
1.27 \\
0.02 \\
0.47 \\
1.37 \\
3.49 \\
4.64 \\
0.15 \\
98.75\end{array}$ & $\begin{array}{r}74.08 \\
0.61 \\
13.56 \\
2.11 \\
1.48 \\
0.05 \\
1.89 \\
3.58 \\
3.60 \\
2.49 \\
0.19 \\
103.64\end{array}$ & $\begin{array}{r}56.77 \\
1.99 \\
17.20 \\
3.49 \\
6.22 \\
0.20 \\
4.34 \\
3.54 \\
3.47 \\
2.59 \\
0.67 \\
100.48\end{array}$ & $\begin{array}{r}78.29 \\
0.10 \\
13.56 \\
1.48 \\
\\
0.03 \\
0.15 \\
0.15 \\
3.58 \\
5.37 \\
0.04 \\
102.75\end{array}$ & $\begin{array}{r}55.97 \\
1.65 \\
15.74 \\
3.15 \\
5.07 \\
0.14 \\
2.10 \\
9.47 \\
3.45 \\
1.99 \\
0.55 \\
99.28\end{array}$ & $\begin{array}{r}62.74 \\
0.80 \\
13.80 \\
2.30 \\
3.95 \\
0.06 \\
2.13 \\
6.53 \\
3.54 \\
2.95 \\
0.29 \\
99.09\end{array}$ & $\begin{array}{r}67.66 \\
0.79 \\
16.99 \\
2.29 \\
3.06 \\
0.17 \\
1.31 \\
3.16 \\
3.51 \\
3.64 \\
0.30 \\
102.88\end{array}$ & $\begin{array}{r}60.96 \\
1.82 \\
18.07 \\
3.32 \\
5.27 \\
0.13 \\
2.90 \\
4.35 \\
3.46 \\
3.20 \\
0.64 \\
104.12\end{array}$ & $\begin{array}{r}61.14 \\
2.22 \\
16.71 \\
3.72 \\
5.54 \\
0.10 \\
2.62 \\
4.50 \\
3.48 \\
3.06 \\
0.78 \\
103.87\end{array}$ \\
\hline $\begin{array}{l}\text { AOJUSTED } \\
\text { SIO2 } \\
\text { TIO2 } \\
\text { AL2O3 } \\
\text { FE203 } \\
\text { FEO } \\
\text { MNO } \\
\text { MGO } \\
\text { CAO } \\
\text { NA2O } \\
\text { K2O } \\
\text { P2O5 }\end{array}$ & $\begin{array}{r}\text { OXIOES } \\
79.09 \\
0.10 \\
10.35 \\
1.57 \\
0.50 \\
0.03 \\
0.14 \\
0.10 \\
3.45 \\
4.63 \\
0.04\end{array}$ & $\begin{array}{r}80.36 \\
0.04 \\
10.85 \\
0.98 \\
\\
0.02 \\
0.05 \\
0.07 \\
3.57 \\
4.03 \\
0.02\end{array}$ & $\begin{array}{r}75.97 \\
0.11 \\
13.34 \\
0.37 \\
0.01 \\
0.30 \\
2.44 \\
3.51 \\
3.91 \\
0.04\end{array}$ & $\begin{array}{r}70.06 \\
0.49 \\
15.90 \\
2.01 \\
1.29 \\
0.02 \\
0.48 \\
1.39 \\
3.53 \\
4.70 \\
0.15\end{array}$ & $\begin{array}{r}71.48 \\
0.59 \\
13.08 \\
2.04 \\
1.43 \\
0.05 \\
1.82 \\
3.45 \\
3.47 \\
2.40 \\
0.18\end{array}$ & $\begin{array}{r}56.50 \\
1.98 \\
17.12 \\
3.47 \\
6.19 \\
0.20 \\
4.32 \\
3.52 \\
3.45 \\
2.58 \\
0.67\end{array}$ & $\begin{array}{r}76.19 \\
0.10 \\
13.20 \\
1.44 \\
0.03 \\
0.15 \\
0.15 \\
3.48 \\
5.23 \\
0.04\end{array}$ & $\begin{array}{r}56.38 \\
1.66 \\
15.85 \\
3.17 \\
5.11 \\
0.14 \\
2.12 \\
9.54 \\
3.48 \\
2.00 \\
0.55\end{array}$ & $\begin{array}{r}63.32 \\
0.81 \\
13.93 \\
2.32 \\
3.99 \\
0.06 \\
2.15 \\
6.59 \\
3.57 \\
2.98 \\
0.29\end{array}$ & $\begin{array}{r}65.77 \\
0.77 \\
16.51 \\
2.23 \\
2.97 \\
0.17 \\
1.27 \\
3.07 \\
3.41 \\
3.54 \\
0.29\end{array}$ & $\begin{array}{r}58.55 \\
1.75 \\
17.35 \\
3.19 \\
5.06 \\
0.12 \\
2.79 \\
4.18 \\
3.32 \\
3.07 \\
0.61\end{array}$ & $\begin{array}{r}58.86 \\
2.14 \\
16.09 \\
3.58 \\
5.33 \\
0.10 \\
2.52 \\
4.33 \\
3.35 \\
2.95 \\
0.75\end{array}$ \\
\hline $\begin{array}{l}Q \\
C \\
O R \\
A B \\
A N \\
A C \\
W D\end{array}$ & $\begin{array}{r}41.431 \\
27.353 \\
27.470 \\
1.519 \\
0.113\end{array}$ & $\begin{array}{r}44.000 \\
0.536 \\
23.789 \\
30.242 \\
0.217\end{array}$ & $\begin{array}{r}35.618 \\
23.111 \\
29.687 \\
9.110\end{array}$ & $\begin{array}{r}28.263 \\
2.840 \\
27.766 \\
29.905 \\
5.890\end{array}$ & $\begin{array}{l}33.082 \\
14.197 \\
29.392 \\
13.013\end{array}$ & $\begin{array}{r}11.892 \\
3.838 \\
15.232 \\
29.222 \\
13.122\end{array}$ & $\begin{array}{r}35.507 \\
1.636 \\
30.883 \\
29.482 \\
0.470\end{array}$ & $\begin{array}{r}9.259 \\
11.845 \\
29.405 \\
21.741\end{array}$ & $\begin{array}{l}16.542 \\
17.592 \\
30.230 \\
13.172\end{array}$ & $\begin{array}{r}23.512 \\
2.186 \\
20.908 \\
28.869 \\
13.333\end{array}$ & $\begin{array}{r}14.263 \\
2.437 \\
18.161 \\
28.119 \\
16.711\end{array}$ & $\begin{array}{r}15.589 \\
1.308 \\
17.409 \\
28.350 \\
16.587\end{array}$ \\
\hline $\begin{array}{l}\text { EN } \\
\text { FS } \\
\text { MT }\end{array}$ & $\begin{array}{l}0.355 \\
1.441\end{array}$ & 0.125 & 0.740 & $\begin{array}{l}1.185 \\
2.802\end{array}$ & $\begin{array}{l}1.222 \\
4.542 \\
0.058 \\
2.952\end{array}$ & $\begin{array}{r}10.757 \\
5.598 \\
5.036\end{array}$ & 0.364 & $\begin{array}{l}9.170 \\
5.268 \\
4.274 \\
4.600\end{array}$ & $\begin{array}{l}7.352 \\
5.354 \\
4.182 \\
3.365\end{array}$ & $\begin{array}{l}3.171 \\
2.662 \\
3.227\end{array}$ & $\begin{array}{l}6.937 \\
4.006 \\
4.623\end{array}$ & $\begin{array}{l}6.282 \\
3.485 \\
5.193\end{array}$ \\
\hline $\begin{array}{l}\text { HM } \\
\text { IL } \\
\text { IN }\end{array}$ & $\begin{array}{l}0.049 \\
0.181\end{array}$ & $\begin{array}{l}0.984 \\
0.043\end{array}$ & $\begin{array}{l}0.374 \\
0.021 \\
0.232\end{array}$ & $\begin{array}{l}0.072 \\
0.923\end{array}$ & 1.118 & 3.761 & $\begin{array}{l}1.440 \\
0.062\end{array}$ & 3.156 & 1.533 & 1.458 & 3.320 & 4.059 \\
\hline $\begin{array}{l}\text { RU } \\
\text { AP } \\
\text { TOT AL } \\
\text { SALIC } \\
\text { FEMIC }\end{array}$ & $\begin{array}{r}0.090 \\
100.002 \\
96.254 \\
3.748\end{array}$ & $\begin{array}{c}0.018 \\
0.048 \\
100.001 \\
98.784 \\
1.217\end{array}$ & $\begin{array}{r}0.091 \\
100.002 \\
97.527 \\
2.475\end{array}$ & $\begin{array}{r}0.360 \\
100.008 \\
94.665 \\
5.343\end{array}$ & $\begin{array}{r}0.434 \\
100.010 \\
89.684 \\
10.326\end{array}$ & $\begin{array}{c}1.579 \\
100.037 \\
73.305 \\
26.732\end{array}$ & $\begin{array}{r}0.064 \\
0.092 \\
100.002 \\
97.979 \\
2.023\end{array}$ & $\begin{array}{r}1.312 \\
100.030 \\
72.250 \\
27.781\end{array}$ & $\begin{array}{r}0.693 \\
100.016 \\
77.536 \\
22.480\end{array}$ & $\begin{array}{r}0.691 \\
100.017 \\
88.807 \\
11.210\end{array}$ & $\begin{array}{r}1.456 \\
100.033 \\
79.692 \\
20.341\end{array}$ & $\begin{array}{r}1.779 \\
100.040 \\
79.242 \\
20.798\end{array}$ \\
\hline
\end{tabular}


TR.ACE ELEMENT ANALYSIS DF WOOO RIVFR' 'FORMATION (PWR)

ALL ELEMENTS REPCRTED IN PPM

\begin{tabular}{|c|c|c|c|c|c|c|c|c|c|c|c|c|c|c|c|c|c|c|c|c|c|c|}
\hline MAS NO. & $\mathbf{Y}$ & $S R$ & SC & NB & LA & BE & $B A$ & B & $2 R$ & $\sin$ & $v$ & $M N$ & SB & AS & $\mathrm{CR}$ & En & $N t$ & MO & $2 N$ & $P B$ & $\mathrm{Cu}$ & $A G$ \\
\hline $\begin{array}{l}615 \\
616\end{array}$ & $\begin{array}{l}20 \\
20\end{array}$ & $\begin{array}{l}500 \\
500\end{array}$ & $\begin{array}{l}15 \\
15\end{array}$ & $\begin{array}{l}20 \\
20\end{array}$ & $\begin{array}{l}100 \\
100\end{array}$ & $\begin{array}{l}7 \\
7\end{array}$ & $\begin{array}{l}3000 \\
3000\end{array}$ & $\begin{array}{l}0 \\
0\end{array}$ & $\begin{array}{l}200 \\
200\end{array}$ & $\begin{array}{l}0 \\
0\end{array}$ & $\begin{array}{l}70 \\
70\end{array}$ & $\begin{array}{l}500 \\
500\end{array}$ & $\begin{array}{l}0 \\
0\end{array}$ & $\begin{array}{l}0 \\
0\end{array}$ & $\begin{array}{l}150 \\
150\end{array}$ & $\begin{array}{l}0 \\
0\end{array}$ & $\begin{array}{l}20 \\
20\end{array}$ & $\begin{array}{l}0 \\
0\end{array}$ & $\begin{array}{l}0 \\
0\end{array}$ & $\begin{array}{l}20 \\
20\end{array}$ & $\begin{array}{l}30 \\
30\end{array}$ & $\begin{array}{l}0.5 \\
0.5\end{array}$ \\
\hline $\begin{array}{l}\text { MINI MUM } \\
\text { MAXI MUM } \\
\text { AVER AGE } \\
\text { S.D. }\end{array}$ & $\begin{array}{r}20 \\
20 \\
20 \\
0\end{array}$ & $\begin{array}{r}500 \\
500 \\
500 \\
0\end{array}$ & $\begin{array}{r}15 \\
15 \\
15 \\
0\end{array}$ & $\begin{array}{r}20 \\
20 \\
20 \\
0\end{array}$ & $\begin{array}{r}100 \\
100 \\
100 \\
0\end{array}$ & $\begin{array}{l}7 \\
7 \\
7 \\
0\end{array}$ & $\begin{array}{r}3000 \\
3000 \\
3000 \\
0\end{array}$ & $\begin{array}{l}0 \\
0 \\
0 \\
0\end{array}$ & $\begin{array}{r}200 \\
200 \\
200 \\
0\end{array}$ & $\begin{array}{l}0 \\
0 \\
0 \\
0\end{array}$ & $\begin{array}{r}70 \\
70 \\
70 \\
0\end{array}$ & $\begin{array}{r}500 \\
500 \\
500 \\
0\end{array}$ & $\begin{array}{l}0 \\
0 \\
0 \\
0\end{array}$ & $\begin{array}{l}0 \\
0 \\
0 \\
0\end{array}$ & $\begin{array}{r}150 \\
150 \\
150 \\
0\end{array}$ & $\begin{array}{l}0 \\
0 \\
0 \\
0\end{array}$ & $\begin{array}{r}20 \\
20 \\
20 \\
0\end{array}$ & $\begin{array}{l}0 \\
0 \\
0 \\
0\end{array}$ & $\begin{array}{l}0 \\
0 \\
0 \\
0\end{array}$ & $\begin{array}{r}20 \\
20 \\
20 \\
0\end{array}$ & $\begin{array}{r}30 \\
30 \\
30 \\
0\end{array}$ & $\begin{array}{l}0.5 \\
0.5 \\
0.5 \\
0.0\end{array}$ \\
\hline
\end{tabular}

S.D. = STANDARD DEVIATION 
TRACE ELEMENT INALYSIS DF PORPHYRITIC QUARTL MONZCNITE (KP)

ALL ELEMENTS PEPCETED IN PPM

\begin{tabular}{|c|c|c|c|c|c|c|c|c|c|c|c|c|c|c|c|c|c|c|c|c|c|c|}
\hline MAS NO. & $Y$ & SR & sr. & NP. & $\ln$ & $B F$ & BA & $B$ & 25 & $S N$ & $v$ & IMN & SB & AS & $C R$ & $\mathrm{CO}$ & NI & MO & $Z N$ & $P B$ & $\mathrm{CU}$ & $A G$ \\
\hline 612 & 0 & 1000 & 0 & 20 & 100 & 10 & 2000 & 0 & $? .00$ & . 0 & 50 & 200 & 0 & 0 & 20 & 0 & 10 & 0 & 0 & 20 & 5 & 0.5 \\
\hline 613 & 0 & $10 \mathrm{n}$ & 3 & 20 & ino & 10 & 2001 & 0 & 100 & 10 & 50 & 200 & 0 & 0 & 20 & 0 & 10 & 0 & 0 & 50 & 0 & 0.5 \\
\hline 614 & 0 & ioon & 0 & 20 & 100 & 10 & 1500 & 0 & 200 & 0 & 50 & 200 & 0 & 0 & 20 & 0 & 10 & 0 & 0 & 20 & 0 & 0.5 \\
\hline 652 & 5 & 300 & 0 & 20 & 0 & 10 & 1500 & 0 & 200 & 0 & 5 & ino & 0 & 0 & 20 & 0 & 10 & 0 & 0 & 50 & 0 & 0.5 \\
\hline 654 & 0 & 700 & 0 & 10 & 50 & 10 & 2000 & 0 & 200 & 0 & 30 & 300 & 0 & 0 & 20 & 0 & 5 & 0 & 0 & 20 & 0 & 0.3 \\
\hline 656 & 5 & $7 n n$ & 0 & 20 & 50 & 10 & 2000 & 0 & 100 & $n$ & 30 & 200 & 0 & 0 & 20 & 5 & 5 & 0 & 0 & 20 & 3 & 0.3 \\
\hline 657 & 10 & 730 & 10 & 20 & 50 & 15 & 2000 & 0 & 100 & 0 & 50 & 300 & 0 & 0 & 50 & 5 & 10 & 0 & 0 & 20 & 0 & 0.5 \\
\hline 658 & 5 & 700 & 0 & 20 & 100 & 7 & 2000 & 0 & 200 & 0 & 50 & 300 & 0 & 0 & 20 & 5 & 10 & 0 & 0 & 20 & 5 & 1.0 \\
\hline 660 & 10 & 700 & 0 & 20 & 100 & 10 & 2000 & 0 & 200 & 0 & 30 & 300 & 0 & 0 & 20 & 5 & 5 & 0 & 0 & 30 & 0 & 1.0 \\
\hline 706 & 10 & 700 & 3 & 50 & 100 & 15 & 1000 & 0 & 200 & 0 & 50 & 300 & 0 & 0 & 50 & 5 & 15 & 0 & 0 & 30 & 5 & 0.0 \\
\hline 708 & 10 & 1000 & 0 & 20 & 100 & 15 & 1000 & 0 & 200 & 0 & 30 & 100 & 0 & 0 & 20 & 0 & 10 & 0 & 0 & 30 & 0 & 0.0 \\
\hline 680 & 10 & 700 & 0 & 20 & 100 & 10 & 1530 & 0 & 200 & 0 & 30 & 200 & 0 & 0 & 20 & 0 & 3 & 0 & 0 & 30 & 0 & 0.3 \\
\hline 718 & 10 & 700 & 0 & 50 & 150 & 7 & 700 & 0 & 200 & 0 & 30 & 200 & 0 & 0 & 20 & 5 & 3 & 0 & 0 & 30 & 3 & 0.3 \\
\hline 737 & 10 & 700 & 0 & 50 & 100 & 15 & 2000 & 0 & 500 & 0 & 30 & 200 & 0 & 0 & 70 & 0 & 10 & 0 & 0 & 30 & 0 & 0.3 \\
\hline 740 & 50 & 500 & 50 & 20 & 0 & 10 & 700 & 5 & 100 & 0 & 300 & 300 & 0 & 500 & 70 & 30 & 30 & 100 & 0 & 1000 & 300 & 5.0 \\
\hline 741 & 20 & 700 & 10 & 50 & 100 & 10 & 3000 & 0 & 200 & 0 & 70 & 200 & 0 & 0 & 50 & 5 & 5 & 0 & 0 & 30 & 5 & 0.3 \\
\hline MINI MUM & 0 & 300 & 0 & 10 & 0 & 7 & 700 & 0 & 100 & 0 & 5 & 100 & 0 & 0 & 20 & 0 & 3 & 0 & 0 & 20 & 0 & 0.0 \\
\hline MAXI MUM & 50 & 1000 & 50 & 50 & 150 & 15 & 3000 & 5 & 500 & 10 & 300 & 300 & 0 & 500 & 70 & 30 & 30 & 100 & 0 & 1000 & 300 & 5.0 \\
\hline AVERAGE & 9 & 737 & 4 & 26 & 81 & 10 & 1681 & 0 & 193 & 0 & 55 & 225 & 0 & 31 & 31 & 4 & 9 & 6 & 0 & 89 & 20 & 0.7 \\
\hline S.0. & 11 & 189 & 12 & 13 & 40 & 2 & 605 & 1 & 92 & 2 & 66 & 68 & 0 & 125 & 19 & 7 & 6 & 25 & 0 & 243 & 74 & \\
\hline
\end{tabular}

S. D. = STANDARD DEVIATION 


\section{Table 2. Trace element analyses}

Semiquantitative spectrographic analyses by Shannon Gore of Specomp Services, Inc., Steamboat Springs, Colorado. The instrument is a Jatre11-Ash 1.5-meter DC-arc emission spectrograph. The lower detection limits in ppm are:

$\begin{array}{lr}\mathrm{Y} & 10 \mathrm{ppm} . \\ \mathrm{Sr} & 100 \\ \mathrm{Sc} & 5 \\ \mathrm{Nb} & 10 \\ \mathrm{La} & 20 \\ \mathrm{Be} & 2 \\ \mathrm{Ba} & 10 \\ \mathrm{~B} & 50 \\ \mathrm{Zr} & 10 \\ \mathrm{Sn} & 10 \\ \mathrm{~V} & 10 \\ \mathrm{Mn} & 10 \\ \mathrm{Sb} & 100 \\ \mathrm{As} & 200 \\ \mathrm{Cr} & 20 \\ \mathrm{Co} & 10 \\ \mathrm{Ni} & 5 \\ \mathrm{Mo} & 5 \\ \mathrm{Zn} & 200 \\ \mathrm{~Pb} & 10 \\ \mathrm{Cu} & 5 \\ \mathrm{Ag} & 0.5\end{array}$


TRACE ELEMENT ANALYSIS OF QUARTZ MONZONITE, EQUIGRANULAR PHASE (KE)

ALL. FLEMENTS REPCRTED IN PPM

\begin{tabular}{|c|c|c|c|c|c|c|c|c|c|c|c|c|c|c|c|c|c|c|c|c|c|c|}
\hline MAS NO. & $Y$ & $S R$ & $5 C$ & $N B$ & LA & a.F. & RA & $B$ & $2 R$ & $S N$ & v & IIN & SB & AS & $C R$ & cn & NI & mo & $Z N$ & $P_{A}$ & $\mathrm{CU}$ & $A G$ \\
\hline 716 & 3 & 1000 & 0 & 20 & 150 & 10 & 2000 & 0 & 300 & 0 & 30 & 200 & 0 & 0 & 20 & 10 & 5 & 0 & 300 & 30 & 0 & 0.0 \\
\hline 728 & 0 & 300 & 0 & 10 & 100 & 10 & 3000 & 0 & 100 & 0 & 20 & 200 & 0 & 0 & 50 & 0 & 20 & 0 & 0 & 30 & 3 & 0.3 \\
\hline 734 & 5 & 200 & 0 & 50 & 100 & 10 & 500 & 0 & 200 & 0 & 15 & 200 & 0 & 0 & 20 & 0 & 10 & 0 & 0 & 70 & 0 & 0.3 \\
\hline 731 & 10 & 500 & 0 & 50 & 100 & 15 & 1500 & 0 & 200 & 0 & 30 & 200 & 0 & 0 & 50 & 0 & 10 & 0 & 0 & 30 & 0 & 0.3 \\
\hline 738 & 10 & 200 & 2 & 20 & 100 & 7 & 1500 & 0 & 100 & 0 & 10 & 50 & 0 & 0 & 20 & 0 & 5 & 0 & 0 & 30 & 0 & 0.3 \\
\hline 739 & 10 & 300 & 0 & 50 & 150 & 10 & 2000 & 0 & 300 & 0 & 10 & 100 & 0 & 0 & 20 & 0 & 3 & 0 & 0 & 30 & 0 & 0.3 \\
\hline 742 & 10 & 700 & 15 & 20 & 100 & 10 & 2000 & 0 & 200 & 0 & 70 & 300 & 0 & 0 & 50 & 5 & 5 & 0 & 2 & 30 & 3 & 0.0 \\
\hline 736 & 10 & 500 & 10 & 50 & 100 & 15 & 2000 & 0 & 100 & 0 & 30 & $2 n 0$ & 0 & 0 & 20 & 5 & 10 & 0 & 0 & 30 & 0 & 0.3 \\
\hline 735 & 20 & 700 & 15 & 50 & 100 & 15 & 2000 & 0 & 200 & 0 & 30 & 200 & 0 & 0 & 20 & 5 & 10 & 0 & $n$ & 200 & 3 & 0.3 \\
\hline MINI AIJM & 0 & 200 & 0 & 10 & 100 & 7 & 500 & 0 & 100 & 0 & 10 & 50 & 0 & 0 & 20 & 0 & 3 & 0 & 3 & 30 & 0 & 0.0 \\
\hline$M A X I M I I M$ & 20 & 1000 & 15 & 50 & 150 & 15 & 3000 & 0 & 300 & 0 & 70 & 300 & 0 & 0 & 50 & 10 & 20 & 0 & 300 & 200 & 3 & 0.3 \\
\hline AVEFAGE & 8 & 488 & 4 & 35 & 111 & 11 & 1833 & 0 & 188 & 0 & 27 & 183 & 0 & 0 & 30 & 2 & 8 & 0 & 33 & 53 & 1 & 0.2 \\
\hline S.D. & 5 & 271 & 6 & 17 & 22 & 2 & 0,61 & 0 & 78 & 0 & 18 & 70 & 0 & 0 & 14 & 3 & 5 & 0 & 100 & 56 & 1 & 0.1 \\
\hline
\end{tabular}

\section{S.D. =STANDARD DEVIATION}


TRACE ELEMENT ANALYSIS OF ALTERED QUARTZ MONZONITE (KE)

ALL ELEMENTS REPORTED IN PP:

\begin{tabular}{|c|c|c|c|c|c|c|c|c|c|c|c|c|c|c|c|c|c|c|c|c|c|c|}
\hline MAS NO. & $Y$ & SR & SC. & NB & LA & $B E$ & BA & B & $Z R$ & SN & $v$ & $M N$ & SA & AS & CR & $\mathrm{CO}$ & MI & MO & $Z N$ & PB & $\mathrm{CU}$ & $\mathbf{A G}$ \\
\hline 677 & 10 & 200 & 0 & 20 & 100 & 7 & 700 & 0 & 200 & 0 & 20 & 100 & 200 & 100 & 50 & 0 & 20 & 0 & 0 & 20 & 5 & 0.3 \\
\hline $\begin{array}{l}\text { MINI MUM } \\
\text { MAXIMUM } \\
\text { AVEP,ACEE } \\
\text { S.D. }\end{array}$ & $\begin{array}{r}10 \\
10 \\
20 \\
0\end{array}$ & $\begin{array}{r}200 \\
200 \\
400 \\
0\end{array}$ & $\begin{array}{l}0 \\
0 \\
0 \\
0\end{array}$ & $\begin{array}{r}20 \\
20 \\
40 \\
0\end{array}$ & $\begin{array}{r}100 \\
100 \\
200 \\
0\end{array}$ & $\begin{array}{r}7 \\
7 \\
14 \\
0\end{array}$ & $\begin{array}{r}700 \\
700 \\
1400 \\
0\end{array}$ & $\begin{array}{l}0 \\
0 \\
0 \\
0\end{array}$ & $\begin{array}{r}200 \\
200 \\
400 \\
0\end{array}$ & $\begin{array}{l}0 \\
0 \\
0 \\
0\end{array}$ & $\begin{array}{r}20 \\
20 \\
40 \\
0\end{array}$ & $\begin{array}{r}100 \\
100 \\
200 \\
0\end{array}$ & $\begin{array}{r}200 \\
200 \\
400 \\
0\end{array}$ & $\begin{array}{r}100 \\
100 \\
200 \\
0\end{array}$ & $\begin{array}{r}50 \\
50 \\
100 \\
0\end{array}$ & $\begin{array}{l}0 \\
0 \\
0 \\
0\end{array}$ & $\begin{array}{r}20 \\
20 \\
40 \\
0\end{array}$ & $\begin{array}{l}0 \\
0 \\
0 \\
0\end{array}$ & $\begin{array}{l}0 \\
0 \\
0 \\
0\end{array}$ & $\begin{array}{r}20 \\
20 \\
40 \\
0\end{array}$ & $\begin{array}{r}5 \\
5 \\
10 \\
0\end{array}$ & $\begin{array}{l}0.3 \\
0.3 \\
0.6 \\
0.0\end{array}$ \\
\hline
\end{tabular}

S.D. = STANOARD DEVIATIUN 
TRACE FLEMENT ANALYSIS OF URANIUM-BEARING OUARTZ MONZONITE (KP)

ALL ELEMENTS REPORTED IN PPM

\begin{tabular}{|c|c|c|c|c|c|c|c|c|c|c|c|c|c|c|c|c|c|c|c|c|c|c|}
\hline MAS NO. & $Y$ & $S R$ & SC & NB & LA & $B E$ & $B A$ & B & $Z R$ & SN & $v$ & MN & SB & AS & $C R$ & $c \cap$ & N I & Mn & $Z N$ & PB & $\mathrm{Cu}$ & $A G$ \\
\hline $\begin{array}{l}693 \\
694 \\
698 \\
699 \\
701\end{array}$ & $\begin{array}{l}10 \\
20 \\
10 \\
10 \\
10\end{array}$ & $\begin{array}{r}300 \\
500 \\
700 \\
700 \\
1000\end{array}$ & $\begin{array}{r}15 \\
10 \\
10 \\
3 \\
10\end{array}$ & $\begin{array}{l}50 \\
20 \\
50 \\
20 \\
20\end{array}$ & $\begin{array}{l}150 \\
100 \\
150 \\
150 \\
150\end{array}$ & $\begin{array}{l}15 \\
15 \\
10 \\
10 \\
15\end{array}$ & $\begin{array}{r}1500 \\
2000 \\
200 \\
3000 \\
2000\end{array}$ & $\begin{array}{l}0 \\
0 \\
0 \\
0 \\
0\end{array}$ & $\begin{array}{l}200 \\
200 \\
300 \\
200 \\
200\end{array}$ & $\begin{array}{l}0 \\
0 \\
0 \\
0 \\
0\end{array}$ & $\begin{array}{l}70 \\
50 \\
50 \\
20 \\
50\end{array}$ & $\begin{array}{l}700 \\
200 \\
200 \\
200 \\
200\end{array}$ & $\begin{array}{r}0 \\
0 \\
200 \\
500 \\
0\end{array}$ & $\begin{array}{r}0 \\
0 \\
0 \\
2000 \\
0\end{array}$ & $\begin{array}{r}50 \\
100 \\
100 \\
20 \\
50\end{array}$ & $\begin{array}{r}10 \\
10 \\
5 \\
20 \\
10\end{array}$ & $\begin{array}{r}15 \\
30 \\
15 \\
3 \\
10\end{array}$ & $\begin{array}{r}0 \\
20 \\
70 \\
100 \\
0\end{array}$ & $\begin{array}{r}0 \\
200 \\
0 \\
700 \\
0\end{array}$ & $\begin{array}{l}20 \\
50 \\
50 \\
70 \\
19\end{array}$ & $\begin{array}{r}0 \\
20 \\
3 \\
3 \\
3\end{array}$ & $\begin{array}{l}0.3 \\
0.3 \\
0.3 \\
0.3 \\
0.0\end{array}$ \\
\hline $\begin{array}{l}\text { MINI MUM } \\
\text { MAXI MUM } \\
\text { AVERAGE } \\
\text { S.D. }\end{array}$ & $\begin{array}{r}10 \\
20 \\
12 \\
4\end{array}$ & $\begin{array}{r}300 \\
1000 \\
640 \\
260\end{array}$ & $\begin{array}{r}3 \\
15 \\
9 \\
4\end{array}$ & $\begin{array}{l}20 \\
50 \\
32 \\
16\end{array}$ & $\begin{array}{r}130 \\
150 \\
140 \\
22\end{array}$ & $\begin{array}{r}10 \\
15 \\
13 \\
2\end{array}$ & $\begin{array}{r}200 \\
3000 \\
1740 \\
1018\end{array}$ & $\begin{array}{l}0 \\
0 \\
0 \\
0\end{array}$ & $\begin{array}{r}200 \\
300 \\
220 \\
44\end{array}$ & $\begin{array}{l}0 \\
0 \\
0 \\
0\end{array}$ & $\begin{array}{l}20 \\
70 \\
48 \\
17\end{array}$ & $\begin{array}{l}200 \\
700 \\
300 \\
223\end{array}$ & $\begin{array}{r}0 \\
500 \\
140 \\
219\end{array}$ & $\begin{array}{r}0 \\
2000 \\
400 \\
894\end{array}$ & $\begin{array}{r}20 \\
100 \\
64 \\
35\end{array}$ & $\begin{array}{r}5 \\
20 \\
12 \\
5\end{array}$ & $\begin{array}{r}3 \\
30 \\
14 \\
9\end{array}$ & $\begin{array}{r}0 \\
100 \\
38 \\
44\end{array}$ & $\begin{array}{r}0 \\
700 \\
180 \\
303\end{array}$ & $\begin{array}{l}10 \\
70 \\
40 \\
24\end{array}$ & $\begin{array}{r}0 \\
20 \\
5 \\
7\end{array}$ & $\begin{array}{l}0.0 \\
0.3 \\
0.2 \\
0.1\end{array}$ \\
\hline
\end{tabular}

S.D. = ST ANDARD DEVIATION 
TRACE ELEMENT ANALYSIS OF PETMATITE DIKE (KP)

ALL ELEMENTS REPORTED IN PPM

\begin{tabular}{|c|c|c|c|c|c|c|c|c|c|c|c|c|c|c|c|c|c|c|c|c|c|c|}
\hline MAS ND. & $Y$ & SR & SC & NB & LA & RE & $B A$ & B & $Z R$ & $S N$ & v & $M N$ & SB & AS & $C R$ & $\mathrm{CO}$ & NI & MD & $Z N$ & P 8 & $\mathrm{CU}$ & $A G$ \\
\hline 702 & 5 & 50 & 0 & 50 & 0 & 7 & 100 & 0 & 0 & 0 & 5 & 200 & 0 & 0 & 20 & 5 & 10 & 0 & 0 & 10 & 0 & 0.0 \\
\hline $\begin{array}{l}\text { MI NI MUM } \\
\text { MAXI I HUM } \\
\text { AVEF AGE } \\
\text { S.D. }\end{array}$ & $\begin{array}{r}5 \\
5 \\
10 \\
0\end{array}$ & $\begin{array}{r}50 \\
50 \\
100 \\
0\end{array}$ & $\begin{array}{l}n \\
0 \\
0 \\
0\end{array}$ & $\begin{array}{r}50 \\
50 \\
100 \\
0\end{array}$ & $\begin{array}{l}0 \\
0 \\
0 \\
0\end{array}$ & $\begin{array}{r}7 \\
7 \\
14 \\
0\end{array}$ & $\begin{array}{r}100 \\
100 \\
200 \\
0\end{array}$ & $\begin{array}{l}0 \\
0 \\
0 \\
0\end{array}$ & $\begin{array}{l}0 \\
0 \\
0 \\
0\end{array}$ & $\begin{array}{l}0 \\
0 \\
0 \\
0\end{array}$ & $\begin{array}{r}5 \\
5 \\
10 \\
0\end{array}$ & $\begin{array}{r}200 \\
200 \\
400 \\
0\end{array}$ & $\begin{array}{l}0 \\
0 \\
0 \\
0\end{array}$ & $\begin{array}{l}0 \\
0 \\
0 \\
0\end{array}$ & $\begin{array}{r}20 \\
20 \\
40 \\
0\end{array}$ & $\begin{array}{r}5 \\
5 \\
10 \\
0\end{array}$ & $\begin{array}{r}10 \\
10 \\
20 \\
0\end{array}$ & $\begin{array}{l}0 \\
0 \\
0 \\
0\end{array}$ & $\begin{array}{l}0 \\
0 \\
0 \\
0\end{array}$ & $\begin{array}{r}10 \\
10 \\
20 \\
0\end{array}$ & $\begin{array}{l}0 \\
0 \\
0 \\
0\end{array}$ & $\begin{array}{l}0.0 \\
0.0 \\
0.0 \\
0.0\end{array}$ \\
\hline
\end{tabular}


TRACE ELEMERT AN!AIYSIS OF APLITE DIKE IN THF QUARTZ MONZONITE (KP)

ALL ELE:AENTS REPCRTEO IN PPM

\begin{tabular}{|c|c|c|c|c|c|c|c|c|c|c|c|c|c|c|c|c|c|c|c|c|c|c|}
\hline MAS ND. & $\mathbf{Y}$ & $S R$ & SC & NB & LA & $B E$ & $B A$ & 8 & $2 R$ & $S N$ & v & $M N$ & SB & AS & $C R$ & $\mathrm{CO}$ & NI & MO & $Z N$ & PB & Cu & $A G$ \\
\hline 707 & 10 & 500 & 0 & 50 & 10 & 15 & $70 \mathrm{C}$ & 0 & 100 & 0 & 10 & 100 & 0 & 0 & 50 & 0 & 15 & 0 & 0 & 30 & 0 & 0.0 \\
\hline MINI MUM M & 10 & 500 & 0 & 50 & 10 & 15 & 700 & 0 & 100 & 0 & 10 & 100 & 0 & 0 & 50 & 0 & 15 & 0 & 0 & 30 & 0 & 0.0 \\
\hline MAXI MUM & 10 & 500 & 0 & 50 & 10 & 15 & 700 & 0 & 100 & 0 & 10 & 100 & 0 & 0 & 50 & 0 & 15 & 0 & 0 & 30 & 0 & 0.0 \\
\hline AV EK AGE & 20 & 1000 & 0 & 100 & 20 & 30 & 1400 & 0 & 200 & 0 & 20 & 200 & 0 & 0 & 100 & 0 & 30 & 0 & 0 & 60 & 0 & 0.0 \\
\hline S.D. & 0 & 0 & 0 & 0 & 0 & 0 & 0 & 0 & 0 & 0 & 0 & 0 & 0 & 0 & 0 & 0 & 0 & 0 & 0 & 0 & 0 & 0.0 \\
\hline
\end{tabular}

S.D. =STANDARD DEVIATION 
TRACE ELEMENT ANALYSIS OF ARKOSES OF COAL CREEK (TSL)

ALL ELEMENTS REPORTED IN PPM

\begin{tabular}{|c|c|c|c|c|c|c|c|c|c|c|c|c|c|c|c|c|c|c|c|c|c|c|}
\hline MAS NO. & $Y$ & SR & SC & NB & LA & $B E$ & $B A$ & B & $Z R$ & SN & $v$ & $M N$ & SB & AS & $C P$ & $\mathrm{CO}$ & NI & MO & $Z N$ & PB & $\mathrm{CU}$ & $A G$ \\
\hline 649 & 0 & 300 & 0 & 20 & 50 & 5 & 2000 & 0 & 200 & 0 & 10 & 100 & 0 & 0 & 20 & 0 & 3 & 0 & 0 & 30 & 0 & 0.3 \\
\hline 650 & 5 & 50 & 0 & 10 & 0 & 7 & 200 & 0 & 100 & 0 & 20 & 200 & 0 & 0 & 100 & 0 & 30 & 0 & 0 & 10 & 20 & 2.0 \\
\hline 695 & 20 & 300 & 10 & 50 & 150 & 15 & 1500 & 0 & 300 & 0 & 50 & 200 & 200 & 100 & 20 & 20 & 20 & 70 & 0 & 30 & 3 & 0.5 \\
\hline $70 n$ & 150 & 200 & 30 & 20 & 100 & 70 & 1500 & 50 & 50 & 0 & 50 & 3000 & 0 & 0 & 50 & 0 & 3 & 0 & 0 & 0 & 3 & 0.0 \\
\hline 696 & 0 & 300 & 0 & 10 & 50 & 7 & 1500 & 0 & 100 & 0 & 10 & 50 & 300 & 0 & 20 & 0 & 10 & 0 & 0 & 20 & 0 & 0.3 \\
\hline 703 & 0 & 300 & 0 & 10 & 100 & 5 & 2000 & 0 & 50 & 0 & 10 & 100 & 5000 & 0 & 20 & 0 & 15 & 70 & 0 & 20 & 3 & 0.0 \\
\hline 710 & 0 & 100 & 0 & 10 & 0 & 7 & 100 & 0 & 100 & 0 & 10 & 30 & 0 & 1000 & 20 & 0 & 3 & 0 & 0 & 30 & 0 & 0.5 \\
\hline 712 & 5 & a & 0 & 20 & 100 & 7 & 200 & 0 & 200 & 0 & 20 & 700 & 0 & 0 & 70 & 0 & 10 & 0 & 0 & 20 & 0 & 0.3 \\
\hline 720 & 0 & 300 & 0 & 20 & 50 & 5 & 2000 & 0 & 50 & 0 & 10 & 50 & 0 & 0 & 20 & 0 & 7 & 0 & 0 & 30 & 0 & 0.3 \\
\hline 721 & 0 & 200 & 0 & 50 & 50 & 5 & 1500 & 0 & 200 & 0 & 20 & 200 & 0 & 0 & 10 & 0 & 7 & 0 & 0 & 30 & 0 & 0.3 \\
\hline 723 & 5 & 100 & 0 & 50 & 100 & 5 & 1000 & 0 & 100 & 0 & 15 & 50 & 0 & 300 & 20 & 0 & 3 & 0 & 0 & 10 & 0 & 0.3 \\
\hline 724 & 0 & 200 & 0 & 50 & 100 & 7 & 1500 & 0 & 200 & 0 & 15 & 50 & 0 & 2000 & 20 & 0 & 3 & 0 & 0 & 20 & 0 & 0.3 \\
\hline 726 & 0 & 700 & 0 & 10 & 0 & 15 & 2000 & 0 & 300 & 0 & 30 & 30 & 0 & 0 & 20 & 0 & 3 & 0 & 0 & 30 & 0 & 0.3 \\
\hline 732 & 20 & 300 & 10 & 50 & 100 & 7 & 1500 & 0 & 300 & 0 & 30 & 100 & 0 & 0 & 20 & 0 & 10 & 0 & 0 & 50 & 10 & 0.3 \\
\hline 733 & 10 & 500 & 3 & 50 & 50 & 7 & 1500 & 0 & 200 & 0 & 20 & 2000 & 0 & 0 & 20 & 0 & 3 & 0 & 0 & 20 & 0 & 0.3 \\
\hline MIN I MUM & 0 & 50 & 0 & 20 & 0 & 5 & 200 & 0 & 50 & 0 & 10 & 30 & 0 & 0 & 10 & 0 & 3 & 0 & 0 & 0 & 0 & 0.0 \\
\hline MAXI MUY & 150 & 500 & 30 & 50 & 150 & 70 & 2000 & 50 & 300 & 0 & 50 & 3000 & 5000 & 2000 & 100 & 20 & 30 & 70 & C & 50 & 20 & 2.0 \\
\hline AVEPAGE & 14 & 256 & 3 & 28 & 66 & 11 & 1373 & 3 & 163 & 0 & 21 & 457 & 366 & 226 & 30 & 1 & 8 & 9 & 0 & 23 & 2 & 0.4 \\
\hline S.D. & 38 & 129 & 8 & 18 & 44 & 16 & 599 & 12 & 91 & 0 & 13 & 856 & 1284 & 556 & 24 & 5 & 7 & 24 & 0 & 11 & 5 & 0.5 \\
\hline
\end{tabular}

S. D. = STANDARD DEVIATION 
TPACE ELEMENT ANALYSIS OF TUFfaCEOUS SANDSTONES DF CMAL CREEK (TSU)

ALL ELEMENJS REPORTED IN PPM

\begin{tabular}{|c|c|c|c|c|c|c|c|c|c|c|c|c|c|c|c|c|c|c|c|c|c|c|}
\hline MAS ND. & $Y$ & $S R$ & SC & $A 1 B$ & $1 A$ & RE & aA & B & $Z P$ & $S N$ & $v$ & $M N$ & $\mathrm{SB}$ & AS & $C R$ & $\mathrm{CO}$ & $N !$ & MO & $7 \mathrm{~N}$ & $P B$ & $\mathrm{Cu}$ & $\Delta G$ \\
\hline $\begin{array}{l}709 \\
719 \\
725\end{array}$ & $\begin{array}{l}10 \\
10 \\
10\end{array}$ & $\begin{array}{l}200 \\
700 \\
500\end{array}$ & $\begin{array}{r}0 \\
15 \\
15\end{array}$ & $\begin{array}{l}20 \\
50 \\
20\end{array}$ & $\begin{array}{l}100 \\
100 \\
100\end{array}$ & $\begin{array}{r}10 \\
7 \\
7\end{array}$ & $\begin{array}{r}100 \\
200 \\
2000\end{array}$ & $\begin{array}{r}20 \\
0 \\
0\end{array}$ & $\begin{array}{l}200 \\
300 \\
200\end{array}$ & $\begin{array}{l}0 \\
0 \\
0\end{array}$ & $\begin{array}{l}30 \\
30 \\
50\end{array}$ & $\begin{array}{l}200 \\
200 \\
300\end{array}$ & $\begin{array}{l}0 \\
0 \\
0\end{array}$ & $\begin{array}{l}0 \\
0 \\
0\end{array}$ & $\begin{array}{l}20 \\
70 \\
70\end{array}$ & $\begin{array}{r}0 \\
5 \\
10\end{array}$ & $\begin{array}{r}5 \\
3 \\
30\end{array}$ & $\begin{array}{l}0 \\
0 \\
0\end{array}$ & $\begin{array}{l}0 \\
0 \\
0\end{array}$ & $\begin{array}{l}30 \\
30 \\
30\end{array}$ & $\begin{array}{r}0 \\
5 \\
10\end{array}$ & $\begin{array}{l}0.3 \\
0.0 \\
0.3\end{array}$ \\
\hline $\begin{array}{l}\text { MINIMUM } \\
\text { MAXI MUM } \\
\text { AVERAGE } \\
\text { S.D. }\end{array}$ & $\begin{array}{r}10 \\
10 \\
10 \\
0\end{array}$ & $\begin{array}{l}200 \\
700 \\
466 \\
251\end{array}$ & $\begin{array}{r}0 \\
15 \\
10 \\
8\end{array}$ & $\begin{array}{l}20 \\
50 \\
30 \\
17\end{array}$ & $\begin{array}{r}100 \\
100 \\
100 \\
0\end{array}$ & $\begin{array}{r}7 \\
10 \\
8 \\
1\end{array}$ & $\begin{array}{r}100 \\
2000 \\
766 \\
1069\end{array}$ & $\begin{array}{r}0 \\
20 \\
6 \\
11\end{array}$ & $\begin{array}{r}200 \\
300 \\
233 \\
57\end{array}$ & $\begin{array}{l}0 \\
0 \\
0 \\
0\end{array}$ & $\begin{array}{l}30 \\
50 \\
36 \\
11\end{array}$ & $\begin{array}{r}200 \\
300 \\
233 \\
57\end{array}$ & $\begin{array}{l}0 \\
0 \\
0 \\
0\end{array}$ & $\begin{array}{l}0 \\
0 \\
0 \\
0\end{array}$ & $\begin{array}{l}20 \\
70 \\
53 \\
28\end{array}$ & $\begin{array}{r}0 \\
10 \\
5 \\
5\end{array}$ & $\begin{array}{l}3 \\
30 \\
12 \\
15\end{array}$ & $\begin{array}{l}0 \\
0 \\
0 \\
0\end{array}$ & $\begin{array}{l}0 \\
0 \\
0 \\
0\end{array}$ & $\begin{array}{r}30 \\
30 \\
30 \\
0\end{array}$ & $\begin{array}{r}0 \\
10 \\
5 \\
5\end{array}$ & $\begin{array}{l}0.0 \\
0.3 \\
0.2 \\
0.2\end{array}$ \\
\hline
\end{tabular}

S.D. =STANDARO DEVIATION 
TRACE ELEYENT ANALYSIS OF ANDESITES OF GONANZA PEAK (TA)

ALL ELEMENTS REPORTED IN PPY

\begin{tabular}{|c|c|c|c|c|c|c|c|c|c|c|c|c|c|c|c|c|c|c|c|c|c|c|}
\hline MAS NO. & $Y$ & $S P$. & SC & $n p$ & LI & $B E$ & BA & $B$ & $Z R$ & SN & $v$ & $\mathrm{M} ! \mathrm{H}$ & SR & AS & $C R$ & $\mathrm{CO}$ & NI & MO & $Z N$ & PB & $\mathrm{CU}$ & $A G$ \\
\hline 601 & 10 & 700 & 20 & 20 & 100 & 10 & 2000 & c & 390 & 10 & 100 & 300 & 0 & 0 & 50 & 10 & 20 & 0 & 0 & 50 & 20 & 1.0 \\
\hline 602 & 10 & 700 & 15 & 20 & 100 & 10 & 2030 & 0 & 200 & 0 & 100 & 500 & 0 & 0 & 50 & 10 & 20 & 0 & 0 & 30 & 20 & 1.0 \\
\hline 603 & 10 & 700 & 15 & 20 & 100 & 10 & 3000 & 0 & 300 & 0 & 70 & 200 & 0 & 0 & 150 & 10 & 20 & 0 & 0 & 50 & 7 & 0.5 \\
\hline 604 & 10 & 700 & 20 & 20 & 100 & 7 & 2000 & 50 & 200 & 0 & 100 & 700 & 0 & 0 & 150 & 10 & 20 & 0 & 0 & 20 & 23 & 1.0 \\
\hline 605 & 20 & 700 & $3 n$ & 20 & 199 & 7 & 2000 & 50 & 300 & 10 & 100 & 1000 & 0 & 0 & 200 & 20 & 30 & 0 & 0 & 30 & 20 & 1.0 \\
\hline 606 & 10 & 700 & 20 & 20 & 100 & 7 & 3000 & 50 & 200 & 0 & 100 & 500 & 0 & 0 & 150 & 10 & 30 & 0 & 0 & 20 & 20 & 1.0 \\
\hline 607 & 20 & 700 & 30 & 20 & 100 & 7 & 3000 & 50 & 300 & 0 & 100 & 530 & 0 & 0 & 150 & 20 & 3.0 & 0 & 0 & 20 & 20 & 1.0 \\
\hline 608 & 10 & 700 & 20 & 20 & 100 & 7 & 3000 & 0 & 300 & 30 & 100 & 300 & 0 & 0 & 500 & 20 & 150 & 0 & 0 & 100 & 30 & 0.5 \\
\hline 309 & 10 & 700 & 20 & 20 & 100 & 7 & 3000 & 0 & 200 & 0 & 100 & $5 \cap 0$ & 0 & 0 & 150 & 10 & 30 & 0 & 0 & 30 & 15 & 0.5 \\
\hline 610 & 10 & 700 & 20 & 20 & 100 & 7 & 3000 & 0 & 300 & 0 & 100 & 300 & 0 & 0 & 300 & 20 & 70 & 0 & 0 & 50 & 30 & 0.5 \\
\hline 611 & 10 & 700 & 20 & 20 & 100 & 7 & 3000 & 0 & 300 & 0 & 120 & 300 & 0 & 0 & 300 & 20 & 100 & 0 & 0 & 50 & 15 & 0.5 \\
\hline 617 & 20 & 700 & 30 & 20 & 100 & 7 & 2000 & 0 & 200 & 0 & 100 & 500 & 0 & 0 & 200 & 20 & 70 & 0 & 0 & 30 & 30 & 0.5 \\
\hline 618 & 20 & 500 & 20 & 20 & I 00 & 7 & 2000 & 0 & 300 & 0 & 70 & 300 & 0 & 0 & $>0$ & 10 & 70 & 0 & 0 & 30 & 20 & 0.5 \\
\hline 619 & 10 & 700 & 20 & 20 & 100 & 7 & 2000 & 0 & 200 & 0 & 100 & 700 & 0 & 0 & 70 & 10 & 30 & 0 & 0 & 30 & 30 & 0.5 \\
\hline 621 & 50 & 700 & 50 & 20 & 100 & 7 & 3000 & 0 & 300 & 0 & 100 & 300 & 0 & 0 & 300 & 20 & 30 & 0 & 0 & 30 & 20 & 0.5 \\
\hline 627 & 20 & 500 & 20 & 20 & 100 & 5 & 1000 & 0 & 300 & 0 & 100 & 500 & 0 & 0 & 50 & 10 & 0 & 0 & 0 & 10 & 20 & 0.0 \\
\hline 663 & 10 & 700 & 15 & 20 & 100 & 10 & 2000 & 0 & 200 & 0 & 50 & 200 & 0 & 0 & 150 & 10 & 30 & 0 & 0 & 50 & 20 & 0.3 \\
\hline 664 & 50 & 500 & 20 & 20 & 100 & 7 & 2000 & 0 & 320 & 0 & 200 & 500 & 0 & 0 & 150 & 10 & 20 & 0 & $n$ & 20 & 15 & 0.3 \\
\hline 665 & 10 & 700 & 15 & 20 & 100 & 7 & 2000 & 0 & 200 & 0 & 70 & 300 & 0 & 0 & 150 & 10 & 30 & 0 & 0 & 50 & 20 & 0.3 \\
\hline 668 & 10 & $7 C 0$ & 20 & 20 & 100 & 7 & 2000 & 5 & 200 & 0 & 100 & 300 & 0 & 0 & 200 & 10 & 50 & 0 & 0 & 30 & 30 & 0.3 \\
\hline 667 & 10 & 700 & 15 & 20 & 100 & 7 & 2000 & 5 & 200 & 0 & 100 & 300 & 0 & 0 & 150 & 10 & 30 & 0 & 0 & 50 & 30 & 0.3 \\
\hline 668 & 100 & 100 & 0 & 100 & 200 & 15 & 500 & 0 & 500 & 0 & 10 & 100 & 0 & 0 & 50 & 0 & 10 & 0 & 0 & 50 & 5 & 0.5 \\
\hline 678 & 10 & 500 & 20 & 20 & 100 & 7 & 2000 & 0 & 300 & 0 & 100 & 200 & 0 & 0 & 200 & 10 & 30 & 0 & 0 & 20 & 15 & 0.3 \\
\hline 685 & 10 & 50 & 15 & 20 & 100 & 7 & 2000 & 0 & 200 & 0 & 100 & 300 & 0 & 0 & 50 & 10 & 20 & 0 & 0 & 30 & 15 & 0.3 \\
\hline 689 & 20 & 700 & 20 & 20 & 100 & 7 & 1500 & 0 & 300 & 0 & 100 & 300 & 0 & 0 & 100 & 20 & 30 & 0 & 0 & 20 & 15 & 0.3 \\
\hline 602 & 10 & 500 & 15 & 20 & 100 & 7 & 2000 & 0 & 200 & 0 & 100 & 500 & 0 & 0 & 100 & 10 & 30 & 0 & 0 & 30 & 20 & 0.3 \\
\hline 711 & 10 & 700 & 20 & 10 & 100 & 7 & 2000 & 5 & 200 & 0 & 70 & 300 & 0 & 0 & 150 & 10 & 30 & 0 & 0 & 50 & 30 & 0.3 \\
\hline 714 & 50 & 700 & 30 & 50 & 100 & 7 & 2000 & 20 & 300 & 0 & 200 & 300 & 0 & 0 & 300 & 20 & 30 & 0 & ) & 10 & 20 & 0.3 \\
\hline 726 & 20 & 700 & 20 & 20 & 100 & 7 & 2000 & 0 & 200 & 0 & 100 & 700 & 0 & 0 & 200 & 20 & 30 & 0 & 0 & 30 & 20 & 0.5 \\
\hline 727 & 10 & 100 & 20 & 50 & 100 & 7 & 3000 & 0 & 100 & 0 & 100 & 700 & 0 & 0 & 300 & 20 & 30 & 0 & 0 & 20 & 20 & 0.0 \\
\hline 876 & 10 & 100 & 10 & 10 & 10 & 10 & 1000 & 10 & 50 & 10 & 75 & 500 & 100 & 200 & 20 & 10 & 10 & 10 & 200 & 40 & 15 & 1.0 \\
\hline MIN IMUM & 10 & 50 & 0 & 10 & 10 & 5 & 500 & 0 & 50 & 0 & 10 & 100 & 0 & 0 & 20 & 0 & 0 & 0 & 0 & 10 & 5 & 0.0 \\
\hline MAXIMUM & 100 & 700 & 50 & 100 & 200 & 15 & 3000 & 50 & 500 & 30 & 200 & 1000 & 100 & 200 & 500 & 20 & 150 & 10 & 200 & 100 & 30 & 1.0 \\
\hline AVERAGE & 19 & 588 & 20 & 23 & 100 & 7 & 2161 & 7 & 246 & 1 & 94 & 416 & 3 & 6 & 169 & 13 & 36 & 0 & 6 & 34 & 20 & 0.5 \\
\hline S.D. & 19 & 209 & 8 & 16 & 24 & 1 & 2245 & 16 & 80 & 6 & 28 & 195 & 17 & 35 & 102 & 5 & 29 & 1 & 35 & 17 & 6 & 0.3 \\
\hline
\end{tabular}

S. $0 .=$ STANDARD DEVIITION 
TRACE element analysis of the nLtereo andesite of BCnanza PeAK, (PK)

ALL ELEMENTS REPORTED IN PPM

\begin{tabular}{|c|c|c|c|c|c|c|c|c|c|c|c|c|c|c|c|c|c|c|c|c|c|c|}
\hline MAS N:O. & $Y$ & Sa & SC & NB & LA & $B E$ & $B A$ & B & $2 P$ & $\mathrm{SN}$ & v & $M N$ & So & AS & $C P$ & CO & N I & $M \Pi$ & $2 N$ & P8 & $\mathrm{CU}$ & $A G$ \\
\hline $\begin{array}{l}686 \\
690\end{array}$ & $\begin{array}{r}0 \\
10\end{array}$ & $\begin{array}{r}50 \\
300\end{array}$ & $\begin{array}{r}0 \\
10\end{array}$ & $\begin{array}{r}0 \\
20\end{array}$ & $\begin{array}{r}0 \\
100\end{array}$ & $\begin{array}{r}10 \\
7\end{array}$ & $\begin{array}{r}500 \\
2000\end{array}$ & $\begin{array}{l}0 \\
0\end{array}$ & $\begin{array}{r}0 \\
200\end{array}$ & $\begin{array}{l}0 \\
0\end{array}$ & $\begin{array}{l}10 \\
50\end{array}$ & $\begin{array}{r}200 \\
50\end{array}$ & $\begin{array}{l}0 \\
0\end{array}$ & $\begin{array}{r}0 \\
500\end{array}$ & $\begin{array}{l}50 \\
50\end{array}$ & $\begin{array}{l}0 \\
0\end{array}$ & $\begin{array}{l}30 \\
15\end{array}$ & $\begin{array}{l}0 \\
0\end{array}$ & $\begin{array}{l}0 \\
0\end{array}$ & $\begin{array}{l}10 \\
30\end{array}$ & $\begin{array}{r}7 \\
10\end{array}$ & $\begin{array}{l}2.0 \\
2.0\end{array}$ \\
\hline $\begin{array}{l}\text { MIN I MUM } \\
\text { MAXI MUM } \\
\text { AVER AGE } \\
\text { S. D. }\end{array}$ & $\begin{array}{r}0 \\
10 \\
5 \\
7\end{array}$ & $\begin{array}{l}50 \\
300 \\
175 \\
176\end{array}$ & $\begin{array}{r}0 \\
10 \\
5 \\
7\end{array}$ & $\begin{array}{l}0 \\
20 \\
10 \\
14\end{array}$ & $\begin{array}{r}0 \\
100 \\
50 \\
70\end{array}$ & $\begin{array}{r}7 \\
10 \\
8 \\
2\end{array}$ & $\begin{array}{r}500 \\
2000 \\
1250 \\
1060\end{array}$ & $\begin{array}{l}0 \\
0 \\
0 \\
0\end{array}$ & $\begin{array}{r}0 \\
200 \\
100 \\
141\end{array}$ & $\begin{array}{l}0 \\
0 \\
0 \\
0\end{array}$ & $\begin{array}{l}10 \\
50 \\
30 \\
28\end{array}$ & $\begin{array}{l}50 \\
200 \\
125 \\
106\end{array}$ & $\begin{array}{l}0 \\
0 \\
0 \\
0\end{array}$ & $\begin{array}{r}0 \\
500 \\
250 \\
353\end{array}$ & $\begin{array}{r}50 \\
50 \\
50 \\
0\end{array}$ & $\begin{array}{l}0 \\
0 \\
0 \\
0\end{array}$ & $\begin{array}{l}15 \\
30 \\
22 \\
10\end{array}$ & $\begin{array}{l}0 \\
0 \\
0 \\
0\end{array}$ & $\begin{array}{l}0 \\
0 \\
0 \\
0\end{array}$ & $\begin{array}{l}10 \\
30 \\
20 \\
24\end{array}$ & $\begin{array}{r}7 \\
10 \\
8 \\
2\end{array}$ & $\begin{array}{l}2.0 \\
2.0 \\
2.0 \\
0.0\end{array}$ \\
\hline
\end{tabular}

S.D. =STANDARD DEVIATION 
trace element analysis of QUaRTz latite pyroclastic tufF (TA)

ALL ELEMFNTS REPCRTED IN PPM

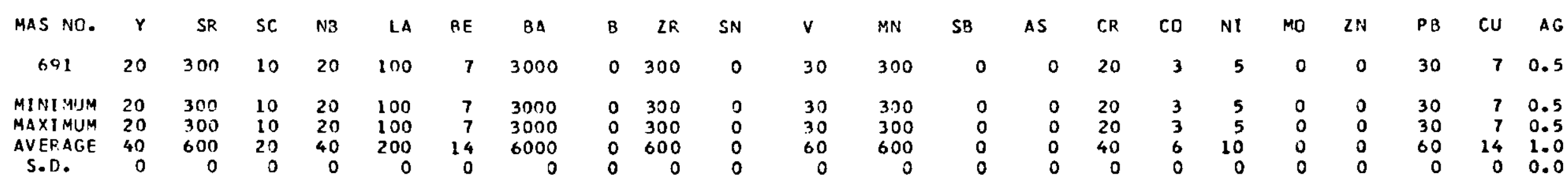

S.D.=STANDARU DEVIATION 
IRACE ELEMENT ANALYSIS OF EPICLASTIC BED (TA)

ALL ELEMENTS REPORTEO IN PPM

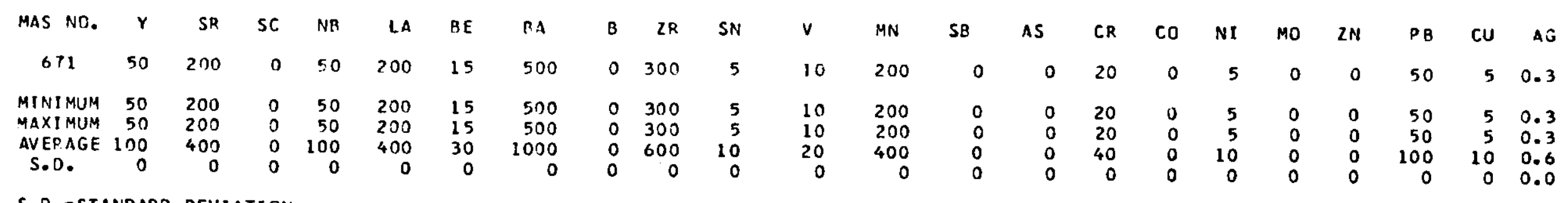

S.D.= STANDARD DEVIATION 
TRACE ELEMENT ANALYSIS OF RHYGDACITE WATER-LAID TUFF (TW)

ALL ELEMENIS R.EPORTEO IN PPM

\begin{tabular}{|c|c|c|c|c|c|c|c|c|c|c|c|c|c|c|c|c|c|c|c|c|c|c|}
\hline MAS NO. & $Y$ & $S R$ & SC & NR & LA & RE & $R A$ & B & $Z R$ & SN & $v$ & MN & SB & AS & $C R$ & 60 & NI & MO & $2 N$ & $P B$ & $\mathrm{Cu}$ & $A G$ \\
\hline $\begin{array}{l}681 \\
684\end{array}$ & $\begin{array}{l}10 \\
20\end{array}$ & $\begin{array}{l}500 \\
700\end{array}$ & $\begin{array}{l}10 \\
20\end{array}$ & $\begin{array}{l}20 \\
20\end{array}$ & $\begin{array}{l}100 \\
100\end{array}$ & $\begin{array}{l}7 \\
7\end{array}$ & $\begin{array}{l}2000 \\
1500\end{array}$ & $\begin{array}{l}0 \\
0\end{array}$ & $\begin{array}{l}200 \\
200\end{array}$ & $\begin{array}{l}0 \\
0\end{array}$ & $\begin{array}{l}50 \\
50\end{array}$ & $\begin{array}{l}200 \\
500\end{array}$ & $\begin{array}{l}0 \\
0\end{array}$ & $\begin{array}{l}0 \\
0\end{array}$ & $\begin{array}{r}20 \\
200\end{array}$ & $\begin{array}{l}10 \\
10\end{array}$ & $20^{3}$ & $\begin{array}{l}0 \\
0\end{array}$ & $\begin{array}{l}0 \\
0\end{array}$ & $\begin{array}{l}30 \\
20\end{array}$ & $\begin{array}{l}15 \\
10\end{array}$ & $\begin{array}{l}0.3 \\
0.3\end{array}$ \\
\hline $\begin{array}{l}\text { MINI MUM } \\
\text { MAXI MUM } \\
\text { AVER AGE } \\
\text { S.D. }\end{array}$ & $\begin{array}{r}10 \\
20 \\
15 \\
7\end{array}$ & $\begin{array}{l}500 \\
700 \\
600 \\
141\end{array}$ & $\begin{array}{r}10 \\
20 \\
15 \\
7\end{array}$ & $\begin{array}{r}20 \\
20 \\
20 \\
0\end{array}$ & $\begin{array}{r}100 \\
100 \\
100 \\
0\end{array}$ & $\begin{array}{l}7 \\
7 \\
7 \\
0\end{array}$ & $\begin{array}{r}1500 \\
2000 \\
1750 \\
353\end{array}$ & $\begin{array}{l}0 \\
0 \\
0 \\
0\end{array}$ & $\begin{array}{r}200 \\
200 \\
200 \\
0\end{array}$ & $\begin{array}{l}0 \\
0 \\
0 \\
0\end{array}$ & $\begin{array}{r}50 \\
50 \\
50 \\
0\end{array}$ & $\begin{array}{l}200 \\
500 \\
350 \\
212\end{array}$ & $\begin{array}{l}0 \\
0 \\
0 \\
0\end{array}$ & $\begin{array}{l}0 \\
0 \\
0 \\
0\end{array}$ & $\begin{array}{r}20 \\
200 \\
110 \\
127\end{array}$ & $\begin{array}{r}10 \\
10 \\
10 \\
0\end{array}$ & $\begin{array}{l}3 \\
20 \\
11 \\
12\end{array}$ & $\begin{array}{l}0 \\
0 \\
0 \\
0\end{array}$ & $\begin{array}{l}0 \\
0 \\
0 \\
0\end{array}$ & $\begin{array}{r}20 \\
30 \\
25 \\
7\end{array}$ & $\begin{array}{r}10 \\
15 \\
12 \\
3\end{array}$ & $\begin{array}{l}0.3 \\
0.3 \\
0.3 \\
0.0\end{array}$ \\
\hline
\end{tabular}

S.D. = STANDARD DEVIATIBN 
TRACE ELEMENT ANALYSIS OF QUARTZ LATITE OF EAST BASIN CREEK (TEB)

ALL ELEMENTS REPCRTEO IN PPM

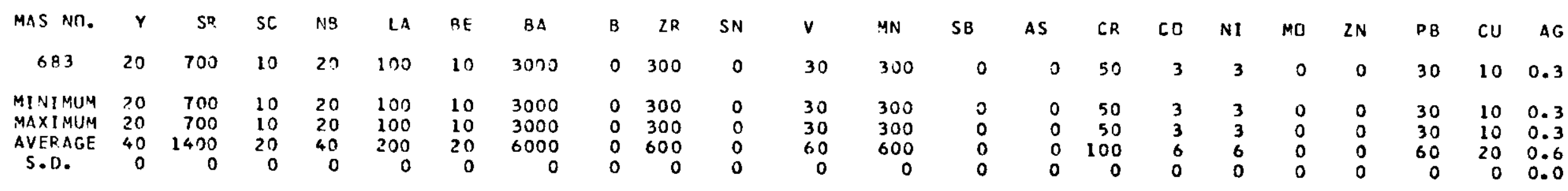

S.D. = STANDARD DEVIATION 
TRACE ELEMENT ANALYSIS OF QUARTZ LATITE LAPILLI TUFF (TL)

ALL ELEMENTS REPORTED IN PPM

\begin{tabular}{|c|c|c|c|c|c|c|c|c|c|c|c|c|c|c|c|c|c|c|c|c|c|c|}
\hline MAS NO. & $Y$ & $S R$ & SC & NB & LA & RE & $B A$ & B & 28 & SN & $v$ & MN & SB & AS & $\tau R$ & $\mathrm{CO}$ & $\mathrm{NI}$ & MO & $2 N$ & $P B$ & $\mathrm{Cu}$ & $A G$ \\
\hline 687 & 10 & 700 & 10 & 20 & 100 & 10 & 2000 & 0 & 200 & 0 & 30 & 200 & 0 & 0 & 100 & 3 & 30 & 0 & 0 & 30 & 7 & 0.3 \\
\hline $\begin{array}{l}\text { MINI MUP } \\
\text { MAXI MUM } \\
\text { AVER AGE } \\
\text { S.D. }\end{array}$ & $\begin{array}{r}10 \\
10 \\
20 \\
0\end{array}$ & $\begin{array}{r}700 \\
700 \\
1400 \\
0\end{array}$ & $\begin{array}{r}10 \\
10 \\
20 \\
0\end{array}$ & $\begin{array}{r}20 \\
20 \\
40 \\
0\end{array}$ & $\begin{array}{r}100 \\
100 \\
200 \\
0\end{array}$ & $\begin{array}{rl}1 & 0 \\
10 \\
20 \\
0\end{array}$ & $\begin{array}{r}2000 \\
2000 \\
4000 \\
0\end{array}$ & $\begin{array}{l}0 \\
0 \\
0 \\
0\end{array}$ & $\begin{array}{r}200 \\
200 \\
400 \\
0\end{array}$ & $\begin{array}{l}0 \\
0 \\
0 \\
0\end{array}$ & $\begin{array}{r}30 \\
30 \\
60 \\
0\end{array}$ & $\begin{array}{r}200 \\
200 \\
400 \\
0\end{array}$ & $\begin{array}{l}0 \\
0 \\
0 \\
0\end{array}$ & $\begin{array}{l}0 \\
0 \\
0 \\
0\end{array}$ & $\begin{array}{r}100 \\
100 \\
200 \\
0\end{array}$ & $\begin{array}{l}3 \\
3 \\
6 \\
0\end{array}$ & $\begin{array}{l}30 \\
30 \\
60 \\
0\end{array}$ & $\begin{array}{l}0 \\
0 \\
0 \\
0\end{array}$ & $\begin{array}{l}0 \\
0 \\
0 \\
0\end{array}$ & $\begin{array}{r}30 \\
30 \\
60 \\
0\end{array}$ & $\begin{array}{r}7 \\
7 \\
14 \\
0\end{array}$ & $\begin{array}{l}0.3 \\
0.3 \\
0.6 \\
0.0\end{array}$ \\
\hline
\end{tabular}

S.0. =STANDARD DEVIATION 
TRACE ELEMENT AISALYSIS OF ANDESITE OF DEADWOOD CREEK (TAN)

ALL ELEMENIS P.EPOPTED IN PPM

\begin{tabular}{|c|c|c|c|c|c|c|c|c|c|c|c|c|c|c|c|c|c|c|c|c|c|c|}
\hline MAS NO. & $\mathbf{Y}$ & SR & SC & NB & LA & BE & BA & B & $Z R$ & SN & $v$ & MN & SB & AS & CR & co & NT & MO & $Z N$ & PB & CU & AG \\
\hline $\begin{array}{l}629 \\
630 \\
631\end{array}$ & $\begin{array}{l}50 \\
50 \\
50\end{array}$ & $\begin{array}{l}500 \\
700 \\
500\end{array}$ & $\begin{array}{l}20 \\
30 \\
30\end{array}$ & $\begin{array}{l}20 \\
20 \\
20\end{array}$ & $\begin{array}{l}100 \\
100 \\
100\end{array}$ & $\begin{array}{l}5 \\
7 \\
7\end{array}$ & $\begin{array}{l}1000 \\
1000 \\
1000\end{array}$ & $\begin{array}{l}0 \\
0 \\
0\end{array}$ & $\begin{array}{l}300 \\
300 \\
300\end{array}$ & $\begin{array}{l}0 \\
0 \\
0\end{array}$ & $\begin{array}{l}100 \\
100 \\
100\end{array}$ & $\begin{array}{l}500 \\
500 \\
500\end{array}$ & $\begin{array}{l}0 \\
0 \\
0\end{array}$ & $\begin{array}{l}0 \\
0 \\
0\end{array}$ & $\begin{array}{l}50 \\
70 \\
70\end{array}$ & $\begin{array}{l}20 \\
20 \\
20\end{array}$ & $\begin{array}{l}15 \\
15 \\
15\end{array}$ & $\begin{array}{l}0 \\
0 \\
0\end{array}$ & $\begin{array}{l}0 \\
0 \\
0\end{array}$ & $\begin{array}{l}10 \\
10 \\
10\end{array}$ & $\begin{array}{l}15 \\
20 \\
15\end{array}$ & $\begin{array}{l}0.0 \\
1.0 \\
0.0\end{array}$ \\
\hline $\begin{array}{l}\text { MINI MUM } \\
\text { MAXIMUY } \\
\text { AVFR.AGE } \\
\text { S.D. }\end{array}$ & $\begin{array}{r}50 \\
50 \\
50 \\
0\end{array}$ & $\begin{array}{l}500 \\
700 \\
566 \\
115\end{array}$ & $\begin{array}{r}20 \\
30 \\
26 \\
5\end{array}$ & $\begin{array}{r}20 \\
20 \\
20 \\
0\end{array}$ & $\begin{array}{r}100 \\
100 \\
100 \\
0\end{array}$ & $\begin{array}{l}5 \\
7 \\
6 \\
1\end{array}$ & $\begin{array}{r}1000 \\
1000 \\
1000 \\
0\end{array}$ & $\begin{array}{l}0 \\
0 \\
0 \\
0\end{array}$ & $\begin{array}{r}300 \\
300 \\
300 \\
0\end{array}$ & $\begin{array}{l}0 \\
0 \\
0 \\
0\end{array}$ & $\begin{array}{r}100 \\
100 \\
100 \\
0\end{array}$ & $\begin{array}{r}500 \\
500 \\
500 \\
0\end{array}$ & $\begin{array}{l}0 \\
0 \\
0 \\
0\end{array}$ & $\begin{array}{l}0 \\
0 \\
0 \\
0\end{array}$ & $\begin{array}{l}50 \\
70 \\
63 \\
11\end{array}$ & $\begin{array}{r}20 \\
20 \\
20 \\
0\end{array}$ & $\begin{array}{r}15 \\
15 \\
15 \\
0\end{array}$ & $\begin{array}{l}0 \\
0 \\
0 \\
0\end{array}$ & $\begin{array}{l}0 \\
0 \\
0 \\
0\end{array}$ & $\begin{array}{r}10 \\
10 \\
10 \\
0\end{array}$ & $\begin{array}{r}15 \\
20 \\
16 \\
2\end{array}$ & $\begin{array}{l}0.0 \\
1.0 \\
0.3 \\
0.6\end{array}$ \\
\hline
\end{tabular}

S.0. =STANDARD DEVIATION 
TRACE ELEMENT ANALYSIS OF TUFF OF DUFFY CREEK [TH]

ALL ELEMENTS REPORTED IN PPM

\begin{tabular}{|c|c|c|c|c|c|c|c|c|c|c|c|c|c|c|c|c|c|c|c|c|c|c|}
\hline MAS NO. & $Y$ & $S R$ & SC & NB & LA & $8 E$ & BA & B & $Z R$ & SN & $v$ & $M N$ & SB & AS & $C R$ & $\mathrm{CD}$ & NI & MO & $Z N$ & PB & $\mathrm{Cu}$ & $\Delta \mathrm{AG}$ \\
\hline $\begin{array}{l}622 \\
624 \\
628 \\
669 \\
670 \\
717 \\
673 \\
675 \\
676 \\
679\end{array}$ & $\begin{array}{r}50 \\
50 \\
10 \\
50 \\
100 \\
50 \\
10 \\
10 \\
10 \\
10\end{array}$ & $\begin{array}{l}300 \\
100 \\
200 \\
100 \\
100 \\
200 \\
700 \\
500 \\
500 \\
500\end{array}$ & $\begin{array}{l}0 \\
0 \\
0 \\
0 \\
0 \\
0 \\
15 \\
20 \\
10 \\
10\end{array}$ & $\begin{array}{l}50 \\
30 \\
20 \\
20 \\
50 \\
50 \\
20 \\
20 \\
20 \\
20\end{array}$ & $\begin{array}{l}100 \\
150 \\
100 \\
100 \\
150 \\
150 \\
100 \\
100 \\
100 \\
100\end{array}$ & $\begin{array}{r}15 \\
15 \\
15 \\
15 \\
15 \\
15 \\
7 \\
7 \\
7 \\
10\end{array}$ & $\begin{array}{r}150 \\
200 \\
1000 \\
1000 \\
200 \\
700 \\
200 \\
1500 \\
2000 \\
1000\end{array}$ & $\begin{array}{l}0 \\
0 \\
0 \\
0 \\
0 \\
0 \\
0 \\
0 \\
0 \\
0\end{array}$ & $\begin{array}{r}300 \\
300 \\
200 \\
200 \\
300 \\
50 \\
200 \\
200 \\
200 \\
200\end{array}$ & $\begin{array}{r}0 \\
0 \\
0 \\
5 \\
10 \\
0 \\
0 \\
0 \\
0 \\
0\end{array}$ & $\begin{array}{r}10 \\
0 \\
15 \\
20 \\
5 \\
15 \\
50 \\
70 \\
50 \\
30\end{array}$ & $\begin{array}{r}100 \\
100 \\
100 \\
100 \\
200 \\
50 \\
300 \\
300 \\
300 \\
100\end{array}$ & $\begin{array}{l}0 \\
0 \\
0 \\
0 \\
0 \\
0 \\
0 \\
0 \\
0 \\
0\end{array}$ & $\begin{array}{l}0 \\
0 \\
0 \\
0 \\
0 \\
0 \\
0 \\
0 \\
0 \\
0\end{array}$ & $\begin{array}{r}20 \\
20 \\
50 \\
20 \\
20 \\
20 \\
150 \\
200 \\
50 \\
50\end{array}$ & $\begin{array}{r}0 \\
0 \\
0 \\
0 \\
0 \\
0 \\
10 \\
10 \\
10 \\
0\end{array}$ & $\begin{array}{r}0 \\
0 \\
30 \\
3 \\
15 \\
0 \\
30 \\
30 \\
15 \\
10\end{array}$ & $\begin{array}{l}0 \\
0 \\
0 \\
0 \\
0 \\
0 \\
0 \\
0 \\
0 \\
0\end{array}$ & $\begin{array}{l}0 \\
0 \\
0 \\
0 \\
0 \\
0 \\
0 \\
0 \\
0 \\
0\end{array}$ & $\begin{array}{l}20 \\
50 \\
30 \\
50 \\
30 \\
30 \\
30 \\
30 \\
30 \\
30\end{array}$ & $\begin{array}{r}5 \\
5 \\
5 \\
7 \\
5 \\
5 \\
15 \\
20 \\
15 \\
5\end{array}$ & $\begin{array}{l}0.5 \\
0.5 \\
0.0 \\
1.0 \\
0.5 \\
0.5 \\
0.3 \\
0.3 \\
0.3 \\
0.3\end{array}$ \\
\hline $\begin{array}{l}\text { MINIMUM } \\
\text { MAXI MUM } \\
\text { AVERAGE } \\
\text { S.D. }\end{array}$ & $\begin{array}{r}10 \\
100 \\
35 \\
30\end{array}$ & $\begin{array}{l}100 \\
700 \\
320 \\
214\end{array}$ & $\begin{array}{r}0 \\
20 \\
5 \\
7\end{array}$ & $\begin{array}{l}20 \\
50 \\
30 \\
14\end{array}$ & $\begin{array}{r}100 \\
150 \\
115 \\
24\end{array}$ & $\begin{array}{r}7 \\
15 \\
12 \\
3\end{array}$ & $\begin{array}{r}150 \\
2000 \\
795 \\
629\end{array}$ & $\begin{array}{l}0 \\
0 \\
0 \\
0\end{array}$ & $\begin{array}{r}50 \\
300 \\
215 \\
74\end{array}$ & $\begin{array}{r}0 \\
10 \\
1 \\
3\end{array}$ & $\begin{array}{r}0 \\
70 \\
26 \\
22\end{array}$ & $\begin{array}{r}50 \\
300 \\
165 \\
100\end{array}$ & $\begin{array}{l}0 \\
0 \\
0 \\
0\end{array}$ & $\begin{array}{l}0 \\
0 \\
0 \\
0\end{array}$ & $\begin{array}{r}20 \\
200 \\
60 \\
63\end{array}$ & $\begin{array}{r}0 \\
10 \\
3 \\
4\end{array}$ & $\begin{array}{l}0 \\
30 \\
13 \\
12\end{array}$ & $\begin{array}{l}0 \\
0 \\
0 \\
0\end{array}$ & $\begin{array}{l}0 \\
0 \\
0 \\
0\end{array}$ & $\begin{array}{r}20 \\
50 \\
33 \\
9\end{array}$ & $\begin{array}{r}5 \\
20 \\
8 \\
5\end{array}$ & $\begin{array}{l}0.0 \\
1.0 \\
0.4 \\
0.3\end{array}$ \\
\hline
\end{tabular}

S.D. = STANDARD DEVIATION 
TRACE ELEMENT ANALYSIS OF ANDESITE DIKFS (TAD)

ALL ELEMENTS REPCRTEO IN PPM

\begin{tabular}{|c|c|c|c|c|c|c|c|c|c|c|c|c|c|c|c|c|c|c|c|c|c|c|}
\hline MAS NC. & $Y$ & $S R$ & SC & NB & LA & $B E$ & BA & 8 & $Z R$ & $S N$ & $v$ & $M N$ & SB & AS & $C R$ & 60 & NI & MO & $2 N$ & PB & $\mathrm{Cu}$ & $A G$ \\
\hline $\begin{array}{l}688 \\
705\end{array}$ & $\begin{array}{l}10 \\
50\end{array}$ & $\begin{array}{l}500 \\
200\end{array}$ & $\begin{array}{l}15 \\
30\end{array}$ & $\begin{array}{l}20 \\
20\end{array}$ & $\begin{array}{l}100 \\
100\end{array}$ & $\begin{array}{l}7 \\
7\end{array}$ & $\begin{array}{l}1500 \\
1000\end{array}$ & $\begin{array}{l}0 \\
0\end{array}$ & $\begin{array}{l}200 \\
300\end{array}$ & $\begin{array}{l}0 \\
0\end{array}$ & $\begin{array}{r}70 \\
100\end{array}$ & $\begin{array}{r}500 \\
1000\end{array}$ & $\begin{array}{l}0 \\
0\end{array}$ & $\begin{array}{l}0 \\
0\end{array}$ & $\begin{array}{l}200 \\
100\end{array}$ & $\begin{array}{l}10 \\
20\end{array}$ & $\begin{array}{l}50 \\
30\end{array}$ & $\begin{array}{l}0 \\
0\end{array}$ & $\begin{array}{l}0 \\
0\end{array}$ & $\begin{array}{l}30 \\
10\end{array}$ & $\begin{array}{l}15 \\
20\end{array}$ & $\begin{array}{l}0.3 \\
0.0\end{array}$ \\
\hline $\begin{array}{l}\text { MINI MIJM } \\
\text { MAXI MU:A } \\
\text { AV ER AGE } \\
\text { S. D. }\end{array}$ & $\begin{array}{l}10 \\
50 \\
30 \\
28\end{array}$ & $\begin{array}{l}200 \\
500 \\
350 \\
212\end{array}$ & $\begin{array}{l}15 \\
30 \\
22 \\
10\end{array}$ & $\begin{array}{r}20 \\
20 \\
20 \\
0\end{array}$ & $\begin{array}{r}100 \\
100 \\
100 \\
0\end{array}$ & $\begin{array}{l}7 \\
7 \\
7 \\
0\end{array}$ & $\begin{array}{r}1000 \\
1500 \\
1250 \\
353\end{array}$ & $\begin{array}{l}0 \\
0 \\
0 \\
0\end{array}$ & $\begin{array}{r}200 \\
300 \\
250 \\
70\end{array}$ & $\begin{array}{l}0 \\
0 \\
0 \\
0\end{array}$ & $\begin{array}{r}70 \\
100 \\
85 \\
21\end{array}$ & $\begin{array}{r}500 \\
1000 \\
750 \\
353\end{array}$ & $\begin{array}{l}0 \\
0 \\
0 \\
0\end{array}$ & $\begin{array}{l}0 \\
0 \\
0 \\
0\end{array}$ & $\begin{array}{r}100 \\
200 \\
150 \\
70\end{array}$ & $\begin{array}{r}10 \\
20 \\
15 \\
7\end{array}$ & $\begin{array}{l}30 \\
50 \\
40 \\
14\end{array}$ & $\begin{array}{l}0 \\
0 \\
0 \\
0\end{array}$ & $\begin{array}{l}0 \\
0 \\
0 \\
0\end{array}$ & $\begin{array}{l}10 \\
30 \\
20 \\
14\end{array}$ & $\begin{array}{r}15 \\
20 \\
17 \\
3\end{array}$ & $\begin{array}{l}0.0 \\
0.3 \\
0.1 \\
0.2\end{array}$ \\
\hline
\end{tabular}

S.D. = STANOARD DEVIATION 
IRACE ELEMENT ANALYSIS OF RHYCLITE OF. WEST FORK [TrW]

ALL ELEIAENTS FEPORTED IN PPM

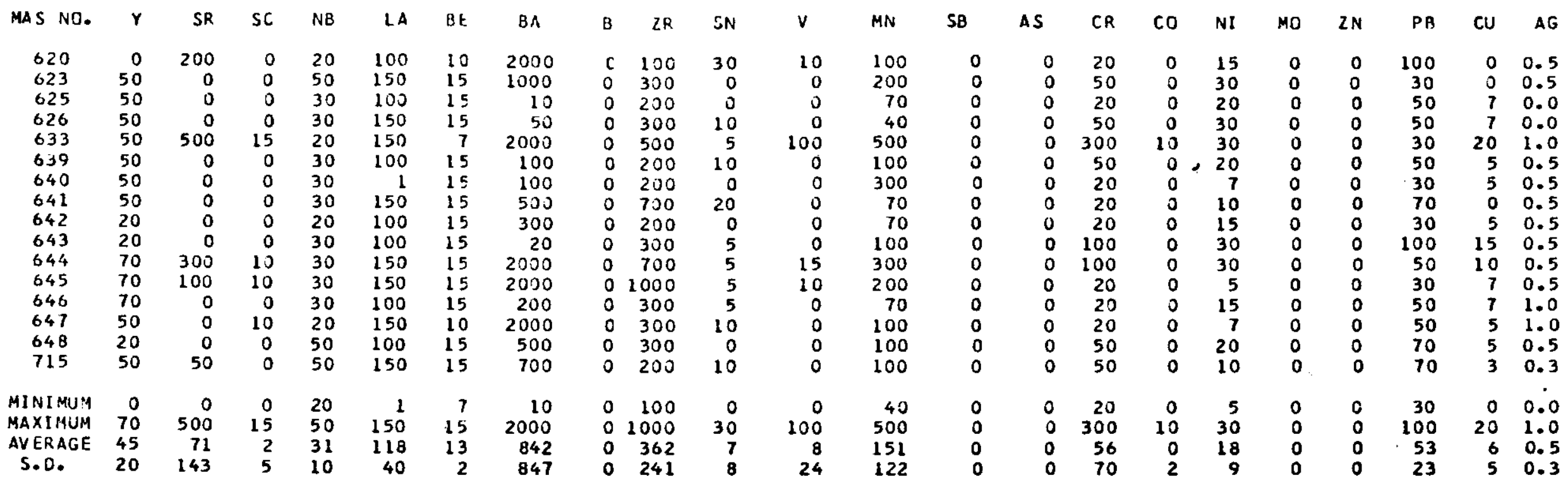

S.0. $=$ STANDARD DEVIATION 
tRaCe element analysis OF RHYOLtTE of MCGCWEN PEAK [Trm]

ALL ELEMENTS REPORTED IN PP!A

\begin{tabular}{|c|c|c|c|c|c|c|c|c|c|c|c|c|c|c|c|c|c|c|c|c|c|c|}
\hline HAS NO. & $\mathbf{Y}$ & SR & SC & NB & LA & $B E$ & $B A$ & B & $2 R$ & SN & $\mathbf{v}$ & MN & SB & AS & CR & $\mathrm{CO}$ & NI & MO & $Z N$ & P B & $\mathrm{Cu}$ & $A G$ \\
\hline $\begin{array}{l}661 \\
662 \\
672 \\
682 \\
704 \\
713 \\
729 \\
730\end{array}$ & $\begin{array}{l}20 \\
10 \\
20 \\
10 \\
10 \\
50 \\
20 \\
50\end{array}$ & $\begin{array}{r}300 \\
200 \\
300 \\
500 \\
200 \\
50 \\
300 \\
50\end{array}$ & $\begin{array}{r}0 \\
0 \\
0 \\
10 \\
3 \\
0 \\
0 \\
0\end{array}$ & $\begin{array}{l}20 \\
20 \\
50 \\
20 \\
20 \\
50 \\
20 \\
50\end{array}$ & $\begin{array}{r}100 \\
100 \\
100 \\
100 \\
100 \\
150 \\
50 \\
150\end{array}$ & $\begin{array}{r}15 \\
10 \\
15 \\
10 \\
7 \\
15 \\
7 \\
15\end{array}$ & $\begin{array}{r}2000 \\
200 \\
700 \\
1500 \\
2000 \\
700 \\
2000 \\
1000\end{array}$ & $\begin{array}{l}0 \\
0 \\
0 \\
0 \\
0 \\
0 \\
0 \\
0\end{array}$ & $\begin{array}{l}200 \\
200 \\
200 \\
300 \\
200 \\
200 \\
200 \\
200\end{array}$ & $\begin{array}{r}0 \\
0 \\
0 \\
0 \\
0 \\
10 \\
0 \\
0\end{array}$ & $\begin{array}{r}10 \\
10 \\
5 \\
50 \\
30 \\
0 \\
30 \\
5\end{array}$ & $\begin{array}{l}200 \\
200 \\
200 \\
300 \\
200 \\
100 \\
100 \\
100\end{array}$ & $\begin{array}{r}0 \\
0 \\
0 \\
0 \\
300 \\
0 \\
0 \\
0\end{array}$ & $\begin{array}{l}0 \\
0 \\
0 \\
0 \\
0 \\
0 \\
0 \\
0\end{array}$ & $\begin{array}{r}20 \\
20 \\
50 \\
150 \\
150 \\
50 \\
50 \\
50\end{array}$ & $\begin{array}{r}0 \\
0 \\
0 \\
10 \\
10 \\
0 \\
0 \\
0\end{array}$ & $\begin{array}{r}10 \\
7 \\
30 \\
10 \\
30 \\
10 \\
15 \\
15\end{array}$ & $\begin{array}{l}0 \\
0 \\
0 \\
0 \\
0 \\
0 \\
0 \\
0\end{array}$ & $\begin{array}{l}0 \\
0 \\
0 \\
0 \\
0 \\
0 \\
0 \\
0\end{array}$ & $\begin{array}{l}50 \\
50 \\
50 \\
30 \\
30 \\
50 \\
30 \\
50\end{array}$ & $\begin{array}{r}7 \\
3 \\
5 \\
15 \\
10 \\
0 \\
3 \\
0\end{array}$ & $\begin{array}{l}0.5 \\
0.5 \\
0.3 \\
0.3 \\
0.0 \\
0.3 \\
0.3 \\
0.3\end{array}$ \\
\hline $\begin{array}{l}\text { MINI MUM } \\
\text { MAXI MUM } \\
\text { AVER AGE } \\
\text { S.D. }\end{array}$ & $\begin{array}{l}10 \\
50 \\
23 \\
16\end{array}$ & $\begin{array}{r}50 \\
500 \\
237 \\
148\end{array}$ & $\begin{array}{r}0 \\
10 \\
1 \\
3\end{array}$ & $\begin{array}{l}20 \\
50 \\
31 \\
15\end{array}$ & $\begin{array}{r}50 \\
150 \\
106 \\
32\end{array}$ & $\begin{array}{r}7 \\
15 \\
11 \\
3\end{array}$ & $\begin{array}{r}200 \\
2000 \\
1262 \\
708\end{array}$ & $\begin{array}{l}0 \\
0 \\
0 \\
0\end{array}$ & $\begin{array}{r}200 \\
300 \\
212 \\
35\end{array}$ & $\begin{array}{r}0 \\
10 \\
1 \\
3\end{array}$ & $\begin{array}{l}0 \\
50 \\
17 \\
17\end{array}$ & $\begin{array}{r}100 \\
300 \\
175 \\
70\end{array}$ & $\begin{array}{r}0 \\
300 \\
37 \\
106\end{array}$ & $\begin{array}{l}0 \\
0 \\
0 \\
0\end{array}$ & $\begin{array}{r}20 \\
150 \\
67 \\
52\end{array}$ & $\begin{array}{r}0 \\
10 \\
2 \\
4\end{array}$ & $\begin{array}{r}7 \\
30 \\
15 \\
9\end{array}$ & $\begin{array}{l}0 \\
0 \\
0 \\
0\end{array}$ & $\begin{array}{l}0 \\
0 \\
0 \\
0\end{array}$ & $\begin{array}{l}30 \\
50 \\
42 \\
.10\end{array}$ & $\begin{array}{r}0 \\
15 \\
5 \\
5\end{array}$ & $\begin{array}{l}0.0 \\
0.5 \\
0.3 \\
0.2\end{array}$ \\
\hline
\end{tabular}

S.0. = STANDARO DEVIATION 
TRACF ELEMENT ANALYSIS DF ALTERED RHYCLITES (TRM, TRW)

ALL ELEMENTS REPORTEO IN PPM

\begin{tabular}{|c|c|c|c|c|c|c|c|c|c|c|c|c|c|c|c|c|c|c|c|c|c|c|}
\hline MAS NO. & $\mathbf{Y}$ & SR & SC & $\mathrm{NB}$ & LA & $B E$ & BA & B & $Z R$ & SN & $v$ & $M N$ & 58 & AS & CR & $\mathrm{CO}$ & N I & MO & $2 N$ & PB & $\mathrm{CU}$ & $A G$ \\
\hline $\begin{array}{l}635 \\
636 \\
638\end{array}$ & $\begin{array}{l}10 \\
70 \\
50\end{array}$ & $\begin{array}{r}0 \\
0 \\
50\end{array}$ & $\begin{array}{l}0 \\
0 \\
3\end{array}$ & $\begin{array}{l}30 \\
30 \\
30\end{array}$ & $\begin{array}{l}100 \\
100 \\
100\end{array}$ & $\begin{array}{r}15 \\
15 \\
7\end{array}$ & $\begin{array}{r}500 \\
300 \\
2000\end{array}$ & $\begin{array}{l}0 \\
0 \\
0\end{array}$ & $\begin{array}{l}300 \\
200 \\
500\end{array}$ & $\begin{array}{r}5 \\
20 \\
0\end{array}$ & $\begin{array}{l}5 \\
0 \\
0\end{array}$ & $\begin{array}{l}100 \\
100 \\
100\end{array}$ & $\begin{array}{l}0 \\
0 \\
0\end{array}$ & $\begin{array}{l}0 \\
0 \\
0\end{array}$ & $\begin{array}{r}100 \\
20 \\
20\end{array}$ & $\begin{array}{l}0 \\
0 \\
0\end{array}$ & $\begin{array}{l}30 \\
20 \\
15\end{array}$ & $\begin{array}{l}0 \\
0 \\
0\end{array}$ & $\begin{array}{l}0 \\
0 \\
0\end{array}$ & $\begin{array}{r}50 \\
100 \\
20\end{array}$ & $\begin{array}{r}10 \\
7 \\
5\end{array}$ & $\begin{array}{l}0.5 \\
0.5 \\
1.0\end{array}$ \\
\hline $\begin{array}{l}\text { MINI MUM } \\
\text { MAXI MUM } \\
\text { AVEF.AGE } \\
\text { S.D. }\end{array}$ & $\begin{array}{l}10 \\
70 \\
43 \\
30\end{array}$ & $\begin{array}{l}0 \\
50 \\
16 \\
28\end{array}$ & $\begin{array}{l}0 \\
3 \\
1 \\
1\end{array}$ & $\begin{array}{r}30 \\
30 \\
30 \\
0\end{array}$ & $\begin{array}{r}100 \\
100 \\
100 \\
0\end{array}$ & $\begin{array}{r}7 \\
15 \\
12 \\
4\end{array}$ & $\begin{array}{r}300 \\
2000 \\
933 \\
929\end{array}$ & $\begin{array}{l}0 \\
0 \\
0 \\
0\end{array}$ & $\begin{array}{l}200 \\
500 \\
333 \\
152\end{array}$ & $\begin{array}{r}0 \\
20 \\
8 \\
10\end{array}$ & $\begin{array}{l}0 \\
5 \\
1 \\
2\end{array}$ & $\begin{array}{r}100 \\
100 \\
100 \\
0\end{array}$ & $\begin{array}{l}0 \\
0 \\
0 \\
0\end{array}$ & $\begin{array}{l}0 \\
0 \\
0 \\
0\end{array}$ & $\begin{array}{r}20 \\
100 \\
46 \\
46\end{array}$ & $\begin{array}{l}0 \\
0 \\
0 \\
0\end{array}$ & $\begin{array}{r}15 \\
30 \\
21 \\
7\end{array}$ & $\begin{array}{l}0 \\
0 \\
0 \\
0\end{array}$ & $\begin{array}{l}0 \\
0 \\
0 \\
0\end{array}$ & $\begin{array}{r}20 \\
100 \\
56 \\
40\end{array}$ & $\begin{array}{r}5 \\
10 \\
7 \\
2\end{array}$ & $\begin{array}{l}0.5 \\
1.0 \\
0.7 \\
0.3\end{array}$ \\
\hline
\end{tabular}

S.0. = STANDARD DEVIATION 
TRACE ELEMENT ANALYSIS OF A URANIUIA-3EARING CHERT VEIN (KP)

ALL ELEMINTS REPOPTEO IN PPM

\begin{tabular}{|c|c|c|c|c|c|c|c|c|c|c|c|c|c|c|c|c|c|c|c|c|c|c|}
\hline MAS NO. & $Y$ & $S R$ & SC & NB & LA & $B E$ & $B A$ & B & $Z R$ & $S N$ & $v$ & $M N$ & SB & AS & $C R$ & $\mathrm{CO}$ & NI & MD & $2 N$ & P B & $\mathrm{CU}$ & $A G$ \\
\hline 697 & 20 & 200 & 10 & 10 & 100 & 15 & 700 & 0 & 100 & 20 & 15 & 100 & 7000 & 700 & 150 & 20 & 100 & 2000 & 700 & 300 & 20 & 0.3 \\
\hline $\begin{array}{l}\text { MINIMUM } \\
\text { MAXIMUM } \\
\text { AVERAGE } \\
\text { S.D. }\end{array}$ & $\begin{array}{r}20 \\
20 \\
40 \\
0\end{array}$ & $\begin{array}{r}200 \\
200 \\
400 \\
0\end{array}$ & $\begin{array}{r}10 \\
10 \\
20 \\
0\end{array}$ & $\begin{array}{r}10 \\
10 \\
20 \\
0\end{array}$ & $\begin{array}{r}100 \\
100 \\
200 \\
0\end{array}$ & $\begin{array}{r}15 \\
15 \\
30 \\
0\end{array}$ & $\begin{array}{r}700 \\
700 \\
1400 \\
0\end{array}$ & $\begin{array}{l}0 \\
0 \\
0 \\
0\end{array}$ & $\begin{array}{r}100 \\
100 \\
200 \\
0\end{array}$ & $\begin{array}{r}20 \\
20 \\
40 \\
0\end{array}$ & $\begin{array}{r}15 \\
15 \\
30 \\
0\end{array}$ & $\begin{array}{r}100 \\
100 \\
200 \\
0\end{array}$ & $\begin{array}{r}7000 \\
7000 \\
14000 \\
0\end{array}$ & $\begin{array}{r}700 \\
700 \\
1400 \\
0\end{array}$ & $\begin{array}{r}150 \\
150 \\
300 \\
0\end{array}$ & $\begin{array}{r}20 \\
20 \\
40 \\
0\end{array}$ & $\begin{array}{r}100 \\
100 \\
200 \\
0\end{array}$ & $\begin{array}{r}2000 \\
2000 \\
4000 \\
0\end{array}$ & $\begin{array}{r}700 \\
700 \\
1400 \\
0\end{array}$ & $\begin{array}{r}300 \\
300 \\
600 \\
0\end{array}$ & $\begin{array}{r}20 \\
20 \\
40 \\
0\end{array}$ & $\begin{array}{l}0.3 \\
0.3 \\
0.6 \\
0.0\end{array}$ \\
\hline
\end{tabular}

S.D.=STANDARD DEVIATION 
TRACE ELEMENT ANALYSIS OF PETRIFIED WOOD [TI]

ALL ELEMENTS REPORTEO IN PPM

\begin{tabular}{|c|c|c|c|c|c|c|c|c|c|c|c|c|c|c|c|c|c|c|c|c|c|c|}
\hline MAS NO. & $\boldsymbol{Y}$ & $S R$ & SC & NB & LA & BE & $B A$ & B & ZR & $S N$ & $v$ & $M N$ & SB & AS & CR & $\mathrm{CO}$ & NI & MO & $2 N$ & PB & $\mathrm{CU}$ & AG \\
\hline 674 & 0 & 50 & 0 & 0 & 0 & 3 & 100 & 0 & 0 & 0 & 0 & 5 & 0 & 100 & 10 & 0 & 10 & 0 & 0 & 0 & 0 & 0.3 \\
\hline $\begin{array}{l}\text { MINI MUM } \\
\text { MAXIMUM } \\
\text { AVERAGE } \\
\text { S.D. }\end{array}$ & $\begin{array}{l}0 \\
0 \\
0 \\
0\end{array}$ & $\begin{array}{r}50 \\
50 \\
100 \\
0\end{array}$ & $\begin{array}{l}0 \\
0 \\
0 \\
0\end{array}$ & $\begin{array}{l}0 \\
0 \\
0 \\
0\end{array}$ & $\begin{array}{l}0 \\
0 \\
0 \\
0\end{array}$ & $\begin{array}{l}3 \\
3 \\
6 \\
0\end{array}$ & $\begin{array}{r}100 \\
100 \\
200 \\
0\end{array}$ & $\begin{array}{l}0 \\
0 \\
0 \\
0\end{array}$ & $\begin{array}{l}0 \\
0 \\
0 \\
0\end{array}$ & $\begin{array}{l}0 \\
0 \\
0 \\
0\end{array}$ & $\begin{array}{l}0 \\
0 \\
0 \\
0\end{array}$ & $\begin{array}{r}5 \\
5 \\
10 \\
0\end{array}$ & $\begin{array}{l}0 \\
0 \\
0 \\
0\end{array}$ & $\begin{array}{r}100 \\
100 \\
200 \\
0\end{array}$ & $\begin{array}{r}10 \\
10 \\
20 \\
0\end{array}$ & $\begin{array}{l}0 \\
0 \\
0 \\
0\end{array}$ & $\begin{array}{r}10 \\
10 \\
20 \\
0\end{array}$ & $\begin{array}{l}0 \\
0 \\
0 \\
0\end{array}$ & $\begin{array}{l}0 \\
0 \\
0 \\
0\end{array}$ & $\begin{array}{l}0 \\
0 \\
0 \\
0\end{array}$ & $\begin{array}{l}0 \\
0 \\
0 \\
0\end{array}$ & $\begin{array}{l}0.3 \\
0.3 \\
0.6 \\
0.0\end{array}$ \\
\hline
\end{tabular}

S.0. ISTANDARD DEVIATION 
Table 3. $\mathrm{U}_{3} 9_{8}$ and thorium analyses and $\mathrm{Th} / \mathrm{U}$ ratios. 
URANIUM ANALYSIS OF WODD RIVER FORMATION (PWR) ALL ELEMENTS REODRTED IN PPM

$\begin{array}{cccc}\text { MAS NO. } & \text { U308 } & \text { TH } & \text { THIU } \\ 615 & 2.0 & 5.0 & 2.9481 \\ 616 & 8.0 & 5.0 & 0.7370 \\ & & & \\ \text { MINIMUM } & 2.0 & 5.0 & 0.7370 \\ \text { MAXIMUM } & 8.0 & 5.0 & 2.9481 \\ \text { AVERAGE } & 5.0 & 5.0 & 1.8426 \\ \text { S.D. } & 4.2 & 0.0 & 1.5635 \\ \text { S.D. STANDARD DEVIATION } & \end{array}$


IJRANIUM ANALYSIS OF DORPHYRITIC QUARTZ MONZONITE (KP) ALL FLFMFNTS REPORTED IN PPM

\begin{tabular}{rrrr} 
MAS NII. & U3D8 & \multicolumn{1}{c}{ TH } & \multicolumn{1}{c}{ TH/U } \\
612 & 0.5 & 7.0 & 16.5094 \\
613 & 1.0 & 9.0 & 10.6132 \\
614 & 2.0 & 11.0 & 6.4859 \\
652 & 0.5 & 4.0 & 9.4340 \\
654 & 0.5 & 10.0 & 23.5849 \\
656 & 2.0 & 16.0 & 9.4340 \\
657 & 9.0 & 0.0 & 1.1792 \\
658 & 3.0 & 16.0 & 6.2893 \\
660 & 3.0 & 14.0 & 5.5031 \\
706 & 10.0 & 23.0 & 2.7123 \\
708 & 3.0 & 10.0 & 3.9308 \\
690 & 6.0 & 9.0 & 1.7689 \\
718 & 1.0 & 13.0 & 15.3302 \\
737 & 2.0 & 20.0 & 11.7925 \\
740 & 466.0 & 5.0 & 0.0127 \\
741 & 8.0 & 20.0 & 2.9481 \\
& & & \\
MINIMUM & 0.5 & 4.0 & 0.0127 \\
MAXIMUM & 466.0 & 23.0 & 23.5849 \\
AVEPAGE & 32.3 & 12.3 & 7.9705 \\
S.D. & 115.7 & 5.5 & 6.4549 \\
S.D. $=$ STANDAED DEVIATIDN &
\end{tabular}


URANIUM ANALYSIS OF QUARTZ MONZONITE, EQUIGRANULAR PHASE (KE) ALL ELEMENTS REPTRTED IN PPM

\begin{tabular}{rrrr} 
MAS MO. & U308 & \multicolumn{1}{c}{ TH } & \multicolumn{1}{c}{ THNU } \\
716 & 9.0 & 17.0 & 2.2275 \\
$7 ? 8$ & 4.0 & 15.0 & 4.4272 \\
734 & 43.0 & 20.0 & 0.5435 \\
731 & 0.5 & 27.0 & 47.1698 \\
738 & 9.5 & 26.0 & 3.2274 \\
739 & 43.0 & 14.0 & 0.3839 \\
742 & 4.0 & 20.0 & 5.8962 \\
736 & 24.0 & 18.0 & 0.8844 \\
735 & 1961.0 & 21.0 & 0.0126 \\
& & & \\
MINIMUM & 0.5 & 14.0 & 0.0126 \\
MAXIMUM & 1961.0 & 26.0 & 47.1698 \\
AVERAGE & 233.1 & 19.0 & 7.1969 \\
S.D. & 648.7 & 3.6 & 15.1235
\end{tabular}

S.D. =STANDARD DEVIATION 
URANIUM ANALYSIS OF ALTERED QUARTZ MONZONITE (KE) ALL ELEMENTS REPORTED IN PPP

\begin{tabular}{crrr} 
MAS N!O. & U308 & \multicolumn{1}{c}{ TH } & TH/U \\
677 & 1.0 & 7.0 & 8.2547 \\
MINIMUM & 1.0 & 7.0 & 8.2547 \\
MAXIMUM & 1.0 & 7.0 & 8.2547 \\
AVERAGE & 2.0 & 14.0 & 16.5094 \\
S.D. & 0.0 & 0.0 & 0.0
\end{tabular}

S.D. =STANDARD DEVIATION 
URANIIIM ANALYSIS OF UPANIUM-BEAR.ING QUARTZ MONZONITE (KP) ALL ELEMENTS REPIRTED IN PPM

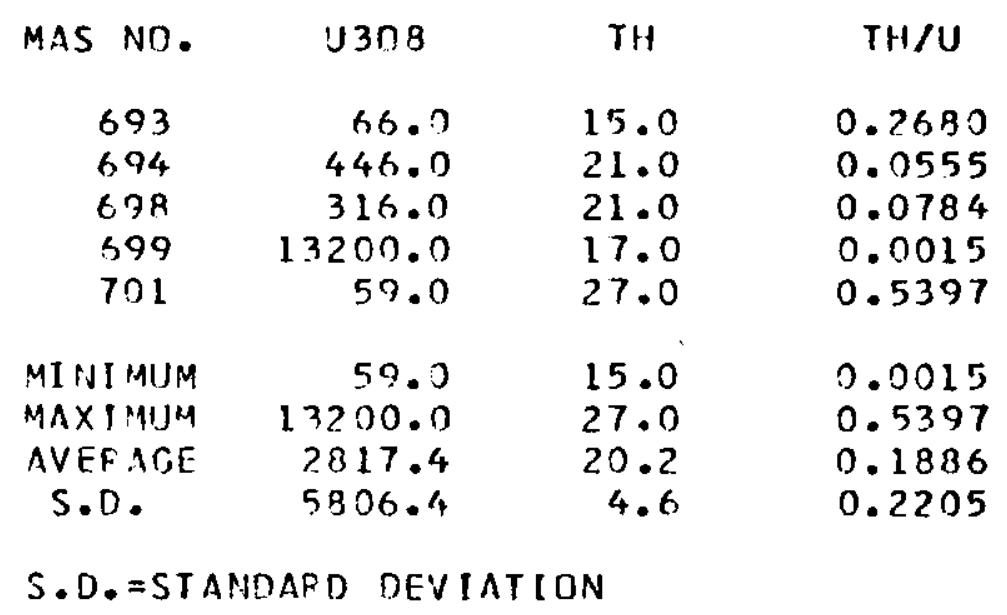


URANIUM ANALYSIS OF PEGMATITE DIKE (KP)

ALL ELEMENTS REPTRTED IN PPI

\begin{tabular}{crrl} 
MAS NO. & J308 & TH & \multicolumn{1}{c}{ TH/U } \\
702 & 14.0 & 6.0 & 0.5054 \\
MINIMUM & 14.0 & 6.0 & 0.5054 \\
MAXIMUM & 14.0 & 6.0 & 0.5054 \\
AVERAGF & 28.0 & 12.0 & 1.0108 \\
S.D. & 0.0 & 0.0 & 0.0
\end{tabular}

S.D. = STANDAR.D DEVIATION 
URANIU:A ANALYSIS OF APLITE DIKE IN THE QUARTZ NONZONITE (KP) ALL ELEMENTS REPTRTED IN PPM

$\begin{array}{cccc}\text { MAS NO. } & \text { U3OB } & \text { TH } & \text { TH/U } \\ 707 & 12.0 & 7.0 & 0.6879 \\ \text { MINIMIJM } & 12.0 & 7.0 & 0.6879 \\ \text { MAXIMUM } & 12.0 & 7.0 & 0.6879 \\ \text { AVERAGF } & 24.0 & 14.0 & 1.3759 \\ \text { S.C. } & 0.0 & 0.0 & 0.0 \\ \text { S.M. STANDARN DEVIATION } & \end{array}$


UP.ANIU:A ANALYSIS OF ARKOSFS CF COAL CREEK (TSL) ALL FLEMENTS RFPORTED IN PPM

\begin{tabular}{|c|c|c|c|}
\hline MAS NO. & J308 & TH & $\mathrm{TH} / \mathrm{U}$ \\
\hline 649 & 22.0 & 5.0 & 0.2680 \\
\hline 650 & 2.0 & 4.0 & 2.3585 \\
\hline 695 & 223.0 & 10.0 & 0.0529 \\
\hline 700 & 457.0 & 14.5 & 0.0374 \\
\hline 696 & 25.0 & 6.0 & 0.2830 \\
\hline 703 & 17.0 & .5 .0 & 0.3468 \\
\hline 710 & 896.0 & 6.0 & 0.0079 \\
\hline 712 & 3.0 & 9.0 & 3.1447 \\
\hline 720 & 4.0 & 7.0 & 2.0637 \\
\hline 721 & 43.0 & 13.0 & 0.3565 \\
\hline 723 & 2.0 & 12.0 & 7.0755 \\
\hline 724 & 0.3 & 7.0 & 27.5157 \\
\hline 726 & 4.0 & 15.0 & 4.4222 \\
\hline 732 & 1.0 & 72.0 & 25.9434 \\
\hline 733 & 2.0 & 12.0 & 7.0755 \\
\hline MINI MIJM & 0.3 & 4.0 & 0.0079 \\
\hline MAXIMUM & 896.0 & 22.0 & 27.5157 \\
\hline AVERAGF: & 113.4 & 9.8 & 5.3968 \\
\hline S.n. & 249.5 & 5.0 & 8.9964 \\
\hline
\end{tabular}


UP. ANIUPA AN!ALYSIS GF TUFFACEOUS SANDSTONES OF CCAL CREEK (TSU) ALL FLEMENTS REPDRTED IN PPM

\begin{tabular}{rrrr} 
MAS NO. & \multicolumn{1}{c}{ U308 } & \multicolumn{1}{c}{ TH } & \multicolumn{1}{c}{ TH/U } \\
709 & 30.0 & 19.0 & 0.7469 \\
719 & 1.0 & 9.0 & 10.6132 \\
725 & 1.0 & 12.0 & 14.1509 \\
& & & \\
MINIMUM & 1.0 & 9.0 & 0.7469 \\
MAXIMUM & 30.0 & 19.0 & 14.1509 \\
AVEPAGE & 10.7 & 13.3 & 8.5037 \\
S.D. & 16.7 & 5.1 & 6.9466
\end{tabular}

S.D. = STANDARD DEVIATINN 
UR.ANIUM ANALYSIS OF ANDESITES OF BONANZA PEAK (TA)

ALL ELEMENTS REPORTED IN PPM

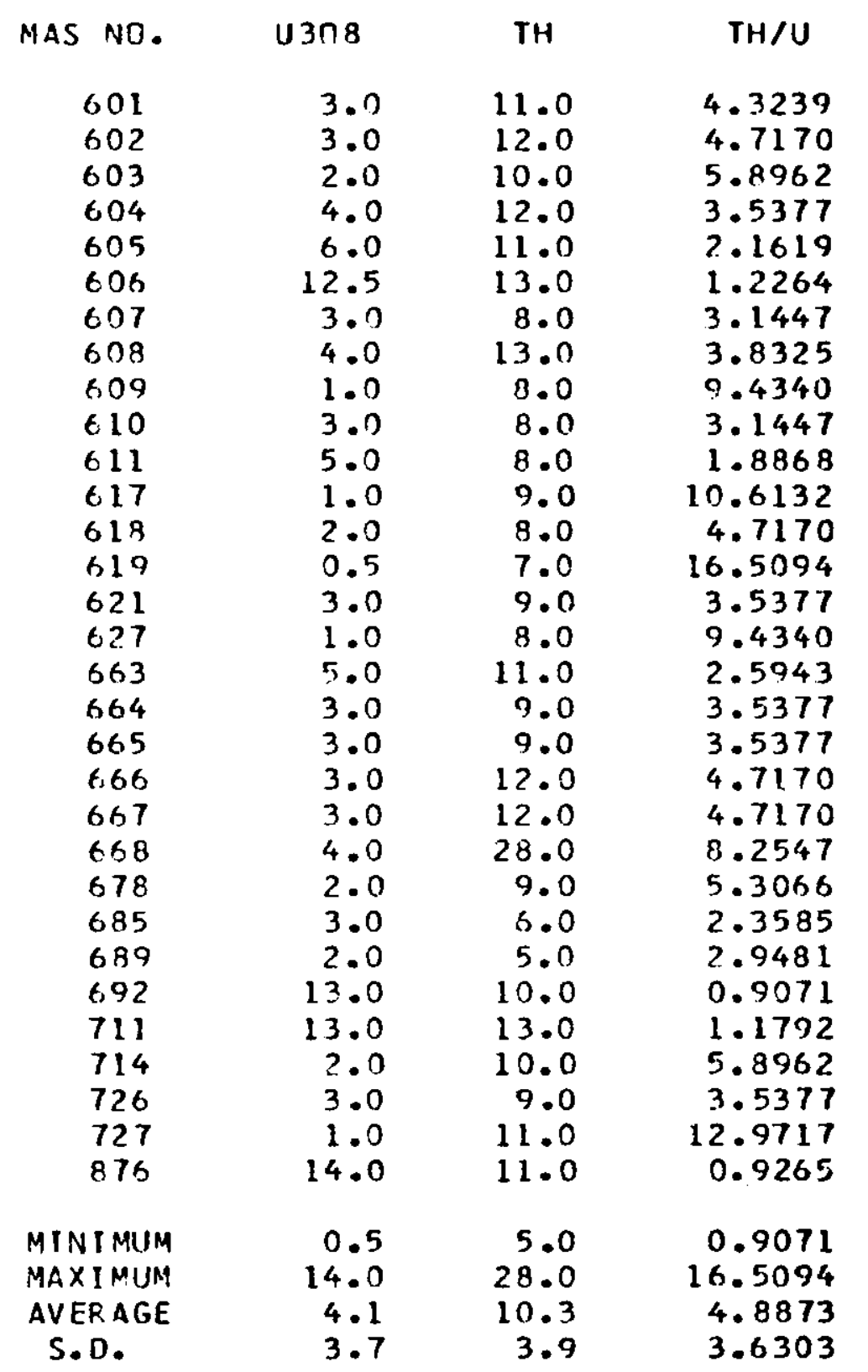

S.D.= STANDAPD DEVIATION 
URANTUM ANALYSIS OF THE aLTERED ANDESITE OF BONANZA PEAK (PK) ALL FLEMENTS REOORTFD IN PPM

\begin{tabular}{rrrr} 
MAS NO. & U308 & \multicolumn{1}{c}{ TH } & TH/U \\
696 & 2.0 & 10.0 & 5.8962 \\
690 & 2.0 & 3.0 & 1.7689 \\
MINIMUM & 2.0 & 3.0 & 1.7689 \\
MAXIMUM & 2.0 & 10.0 & 5.8962 \\
AVERAGE & 2.0 & 6.5 & 3.8325 \\
S.D. & 0.0 & 4.9 & 2.9185
\end{tabular}

S.D. $=S T A N D A R D$ DEVIATION 
UPANIUIA ANALYSIS OF QUAPTZ LATITE PYRDCLASTIC TUFF (TA) ALL ELEMFNTS PEPORTEO IN PPM

$\begin{array}{crcr}\text { MAS NO. } & \text { U308 } & \text { TH } & \text { TH/U } \\ 691 & 0.5 & 4.0 & 9.4340 \\ \text { MINIMIJM } & 0.5 & 4.0 & 9.4340 \\ \text { MAXI 1UM } & 0.5 & 4.0 & 9.4340 \\ \text { AVEF AGE } & 1.0 & 8.0 & 19.8679 \\ \text { S.D. } & 0.0 & 0.0 & 0.0\end{array}$

S.D. =STANOAPD DEVIATIIN 
URANIUM ANALYSIS OF EPICLASTIC BED (TA)

ALL ELEMENTS REPORTED IN PPM

$\begin{array}{crcc}\text { MAS NO. } & \text { U308 } & \text { TH } & \text { TH/U } \\ 671 & 4.0 & 27.0 & 7.9599 \\ \text { MINIMUM } & 4.0 & 27.0 & 7.9599 \\ \text { MAXIMUM } & 4.0 & 27.0 & 7.9599 \\ \text { AVERAGE } & 8.0 & 54.0 & 15.9198 \\ \text { S.D. } & 0.0 & 0.0 & 0.0\end{array}$

S.0. =STANDARD DEVIATION 
URANIUM ANALYSIS OF P.HYODACITE WATER-LAIO TUFF (TW)

ALL FLEMENTS REPDRTED IN PPM

\begin{tabular}{rrrr} 
MAS NO. & U308 & \multicolumn{1}{c}{ TH } & TH/U \\
681 & 3.0 & 15.0 & 5.8962 \\
684 & 3.0 & 9.0 & 3.5377 \\
& & & \\
MINIMUM & 3.0 & 9.0 & 3.5377 \\
MAXIMUM & 3.0 & 15.0 & 5.3962 \\
AVER AGE & 3.0 & 12.0 & 4.7170 \\
S.D. & 0.0 & 4.2 & 1.6677
\end{tabular}

S.D.=STANDARD DEVIATION 
URANIUIA ANALYSIS OF QUAPTZ LATITE OF EAST BASIN CREEK (TEB) ALL FLEMENTS REPORTED IN PPM

$\begin{array}{cccc}\text { MAS NOI. } & \text { U308 } & \text { TH } & \text { TH/U } \\ 683 & 4.0 & 12.0 & 3.5377 \\ \text { MINIMUM } & 4.0 & 12.0 & 3.5377 \\ \text { MAXIMUM } & 4.0 & 12.0 & 3.5377 \\ \text { AVERAGE } & 8.0 & 24.0 & 7.0755 \\ \text { S.D. } & 0.0 & 0.0 & 0.0 \\ \text { S.D. STANDAPD DEVIATION } & \end{array}$




\section{UPANIUIA ANALYSIS DF OUARTZ I.ATITE LAPILLI TUFF (TL) ALL. ELEMENTS REPDRTED IN PPM}

$\begin{array}{crrr}\text { MAS NO. } & \text { U3O8 } & \text { TH } & \text { TH/U } \\ 687 & 1.0 & 6.0 & 7.0755 \\ \text { MINIMUIA } & 1.0 & 6.0 & 7.0755 \\ \text { MAXIMUM } & 1.0 & 6.0 & 7.0755 \\ \text { AVEFAGE } & 2.0 & 12.0 & 14.1509 \\ \text { S.D. } & 0.0 & 0.0 & 0.0\end{array}$

S.D. = STANDARD DEVIATION 
UR.ANTUM ANALYSIS OF ANDESITE OF DEADWODD CREEK (TAN) ALL FLEMENTS REPORTED IN PPM

$\begin{array}{cccc}\text { MAS NO. } & \text { U308 } & \text { TH } & \text { TH/U } \\ 629 & 1.0 & 8.0 & 9.4340 \\ 630 & 1.0 & 7.0 & 8.2547 \\ 631 & 1.0 & 8.0 & 9.4340 \\ \text { MINIMUIA } & 1.0 & 7.0 & 8.2547 \\ \text { MAXINUU' } & 1.0 & 8.0 & 9.4340 \\ \text { AVERACE } & 1.0 & 7.7 & 9.0409 \\ \text { S.D. } & 0.0 & 0.6 & 0.6809 \\ \text { S.D. STIANDARD DEVIATION } & \end{array}$


UP.ANIUM ANALYSIS CF TUFF OF CUFFY CREEK[Tt] ALL ELEMENTS REPORTED IN PPM

\begin{tabular}{|c|c|c|c|}
\hline MAS NO. & 4308 & $\mathrm{TH}$ & $\mathrm{IH} / \mathrm{U}$ \\
\hline $\begin{array}{l}622 \\
624 \\
628 \\
669 \\
670 \\
717 \\
673 \\
675 \\
676 \\
679\end{array}$ & $\begin{array}{r}9.0 \\
12.0 \\
6.0 \\
4.0 \\
6.0 \\
5.0 \\
3.0 \\
2.0 \\
3.0 \\
5.0\end{array}$ & $\begin{array}{r}32.0 \\
33.0 \\
12.0 \\
27.0 \\
29.0 \\
30.0 \\
8.0 \\
9.0 \\
5.0 \\
14.0\end{array}$ & $\begin{array}{l}4.1929 \\
3.2429 \\
2.3585 \\
7.9599 \\
5.6997 \\
7.0755 \\
3.1447 \\
5.3066 \\
1.9654 \\
3.3019\end{array}$ \\
\hline $\begin{array}{l}\text { MINIMUM } \\
\text { IANXIMUM } \\
\text { AVER.AGE } \\
\text { S.U. }\end{array}$ & $\begin{array}{r}2.0 \\
12.0 \\
5.5 \\
3.0\end{array}$ & $\begin{array}{r}5.0 \\
33.0 \\
19.9 \\
11.2\end{array}$ & $\begin{array}{l}1.9654 \\
7.9599 \\
4.4248 \\
2.0165\end{array}$ \\
\hline
\end{tabular}


URANIUM ANALYSIS OF ANDESITE DIKES (TAD)

ALL ELEMENTS REPORTED IN PPM

\begin{tabular}{crrr} 
MAS NO. & U308 & TH & \multicolumn{1}{c}{ TH/U } \\
688 & 2.0 & 12.0 & 7.0755 \\
705 & 0.5 & 7.0 & 16.5094 \\
& & & \\
MINIMUM & 0.5 & 7.0 & 7.0755 \\
MAXI MUM & 2.0 & 12.0 & 16.5094 \\
AVERAGE & 1.3 & 9.5 & 11.7924 \\
S.D. & 1.1 & 3.5 & 6.6708 \\
S.D. = STANDARD & DEVIATION
\end{tabular}




\section{URANIUM ANALYSIS OF RHYOLITE OF WEST FORK [TrW]}

\section{ALL ELEMENTS REPORTEO IN PPM}

\begin{tabular}{rrrr} 
MAS NO. & U3O8 & \multicolumn{1}{c}{ TH } & \multicolumn{1}{c}{ TH/U } \\
620 & 6.0 & 17.0 & 3.3412 \\
623 & 5.0 & 17.0 & 4.0094 \\
625 & 3.0 & 30.0 & 11.7925 \\
626 & 3.0 & 29.0 & 11.3994 \\
633 & 1.0 & 9.0 & 10.6132 \\
639 & 5.0 & 29.0 & 6.8396 \\
640 & 5.0 & 28.0 & 6.6038 \\
641 & 5.0 & 22.0 & 5.1837 \\
642 & 6.0 & 27.0 & 5.3066 \\
643 & 2.0 & 19.0 & 11.2028 \\
644 & 2.0 & 9.0 & 5.3066 \\
645 & 2.0 & 14.0 & 8.2547 \\
646 & 8.0 & 26.0 & 3.8325 \\
647 & 2.0 & 12.0 & 7.0755 \\
648 & 3.0 & 22.0 & 8.6478 \\
715 & 4.0 & 26.0 & 7.6651 \\
& & & \\
MINIMUM & 1.0 & 9.0 & 3.3412 \\
MAXIMUM & 8.0 & 30.0 & 11.7925 \\
AVERAGE & 3.9 & 21.0 & 7.3175 \\
S. D. & 1.9 & 7.3 & 2.8015
\end{tabular}

S.D. = STANDARD DEVIATION 
URANIUM ANALYSIS OF RHYOLITE OF MCGOWEN PEAK [Trm] ALL ELEMENTS REPORTEO IN PPM

\begin{tabular}{ccrr} 
MAS NO. & U3O8 & \multicolumn{1}{c}{ TH } & TH/U \\
& & & \\
661 & 6.0 & 25.0 & 4.9135 \\
662 & 5.0 & 23.0 & 5.4245 \\
672 & 3.0 & 24.0 & 9.4340 \\
682 & 4.0 & 10.0 & 2.9481 \\
704 & 8.0 & 8.0 & 1.1792 \\
713 & 3.0 & 35.0 & 13.7579 \\
729 & 3.0 & 14.0 & 5.5031 \\
730 & 2.0 & 27.0 & 15.9198 \\
MINIMUM & 2.0 & 8.0 & 1.1792 \\
MAXIMUM & 8.0 & 35.0 & 15.9198 \\
AVEFAGE & 4.3 & 20.8 & 7.3850 \\
S.D. & 2.0 & 9.3 & 5.2009 \\
S.D. S. STANDARD & DEVIATICN &
\end{tabular}


UPANIUM ANALYSIS OF ALTERED RHYOLITES (TRM, TRW)

\section{ALL ELEMENTS REPORTED IN PPM}

\begin{tabular}{rrrr} 
MAS NO. & U308 & \multicolumn{1}{c}{ TH } & \multicolumn{1}{c}{ TH/U } \\
6.35 & 11.0 & 31.0 & 3.3233 \\
636 & 12.0 & 41.0 & 4.0291 \\
638 & 0.5 & 8.0 & 18.8679 \\
& & & \\
MINIMUM & 0.5 & 8.0 & 3.3233 \\
MAXIMU4 & 12.0 & 41.0 & 18.8679 \\
AVERAGE & 7.8 & 26.7 & 8.7401 \\
S.D. & 6.4 & 16.9 & 8.7780 \\
S.D. = STANDAP.D DEVIATION &
\end{tabular}


URANIUM ANALYSIS OF A LIRANIUM-BEARING CHERT VEIN (KP) ALL ELEYENTS REPORTED IN PPM

\begin{tabular}{rrrl} 
MAS NO. & U308 & TH & \multicolumn{1}{c}{ TH/U } \\
697 & 12300.0 & 8.0 & 0.0008 \\
MINTMUM & 12300.0 & 8.0 & 0.0008 \\
MAXINUM & 12300.0 & 8.0 & 0.0008 \\
AVEFACE & 24600.0 & 16.0 & 0.0015 \\
S.D. & 0.0 & 0.0 & 0.0
\end{tabular}

S.D. = STANDAR.D DFVIATION 
URANIUM ANALYSIS OF PETRIFIED WCCO[TH]

ALL ELEMENTS REPORTED IN PPM

$\begin{array}{crcc}\text { MAS NO. } & \text { U308 } & \text { TH } & \text { TH/U } \\ 674 & 0.5 & 4.0 & 9.4340 \\ \text { MINIMUM } & 0.5 & 4.0 & 9.4340 \\ \text { MAXIMUM } & 0.5 & 4.0 & 9.4340 \\ \text { AVERAGE } & 1.0 & 8.0 & 18.8679 \\ \text { S.D. } & 0.0 & 0.0 & 0.0\end{array}$

S.D. = STANDARD DEVIATION 



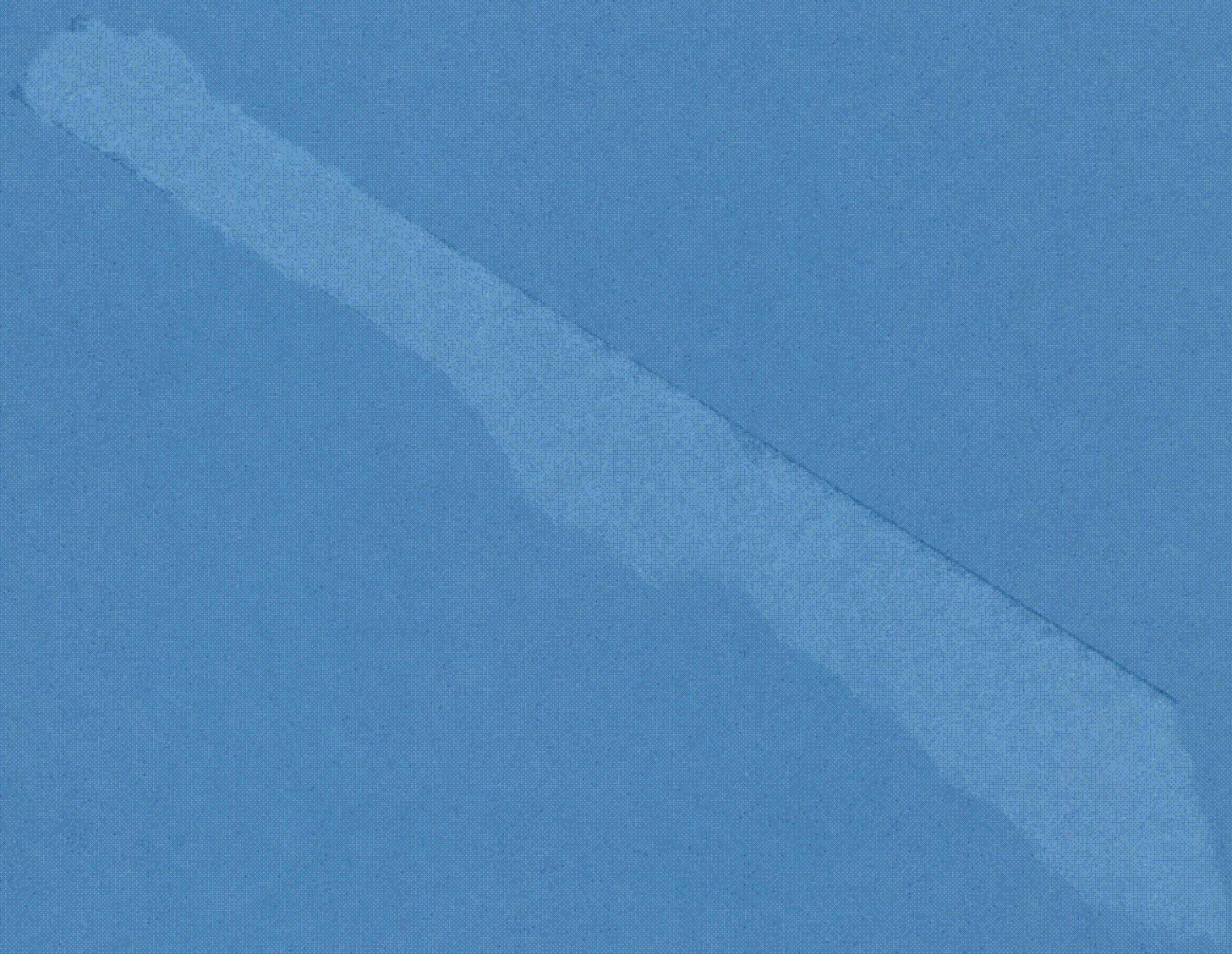


